\title{
Translating the Narrative: an Approach to the Conceptual Design of a Contemporary Orthodox Christian Church
}

\author{
by
}

Anastasiya Burchevska

A thesis submitted to the Faculty of Graduate and Postdoctoral Affairs in partial fulfillment of the requirements for the degree of

\author{
Master \\ In \\ Architecture \\ Carleton University \\ Ottawa, Ontario
}

(C) 2016

Anastasiya Burchevska 


\section{Abstract}

The conceptual design approach is meant to address the challenges faced by an architect when it comes to creating a contemporary Orthodox Christian church. The design would have to adapt to various urban, architectural and social conditions that significantly differ from those of the previous eras.

This design approach establishes a framework that allows the integration of the various design aspects of such a complex architectural object as the Orthodox Christian church at the conceptual design stage.

This thesis focuses on the creation of the architectural narrative or the information layer integrated in the building design as a method of communicating a theological concept in terms applicable to the current cultural and temporal context. 


\section{Table of Contents}

Translating the Narrative: an Approach to the Conceptual Design of a Contemporary

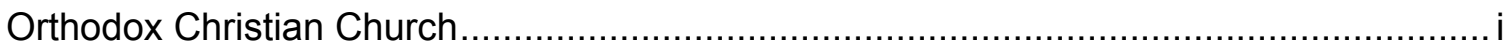

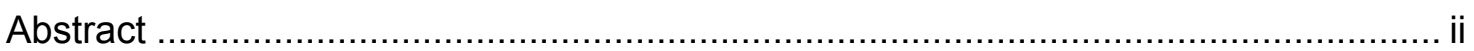

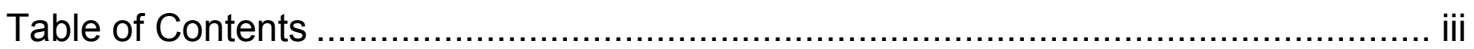

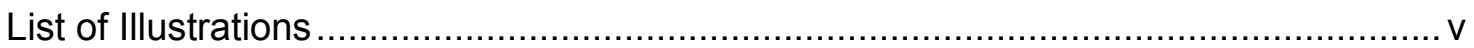

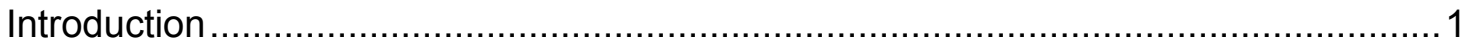

Issues and Challenges of the Contemporary Designing and Building of Churches ......3

The Symbolism of the Orthodox Christian Church ................................................ 7

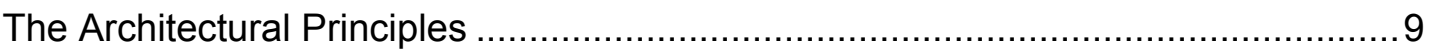

The Architectural Design Components and Their Combinations .........................13

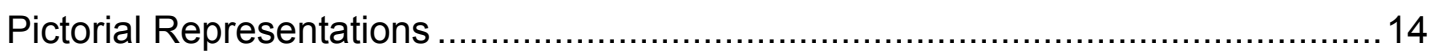

General Guidelines for Design and Construction of Contemporary Orthodox Christian

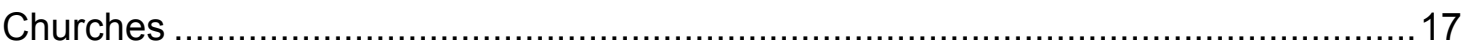

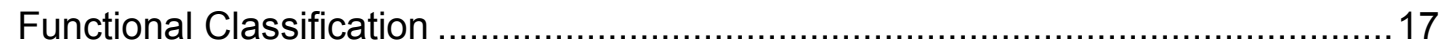

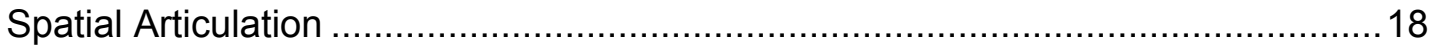

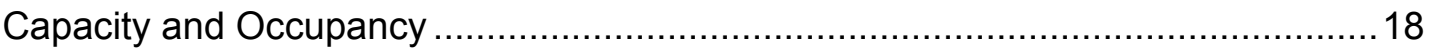

Combination with Other Buildings of the Church Complex ............................... 19

Accommodation to Urban Surroundings ................................................. 19

The Climatic Conditions and the Requirements for Creating Favorable Sanitary

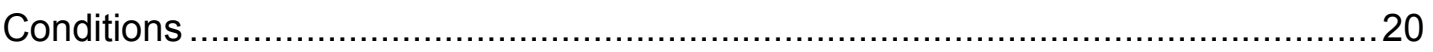

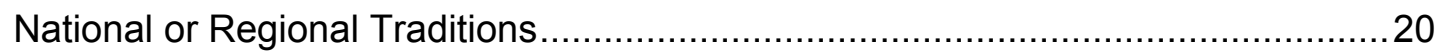


The Common Building Materials

The Preferences of the Client (Church Community), the Designer and the

Contractor 21

Supplementary Design Considerations

Precedent - The Russian Cultural and Spiritual Center in Paris (2011). .23

Theoretical Considerations for Development of the Design Approach: Conceptual

Design Elements and Limits of Experiment in Architecture

Design Elements

The Limits of an Experiment in Architecture 36

The Approach to the Conceptual Design of the Contemporary Orthodox Christian

Church and its Applications 42

The Conceptual Design Approach Outline ...................................................42

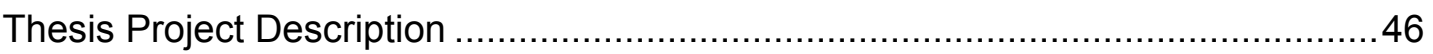

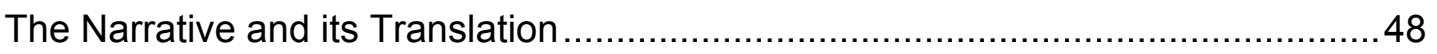

Description of the Spaces in the Church Complex...............................................50

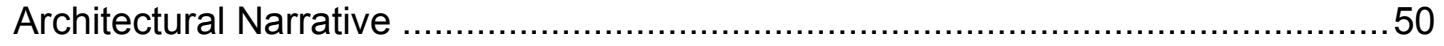

Verbal Narrative as Part of the Design Process.....................................................55

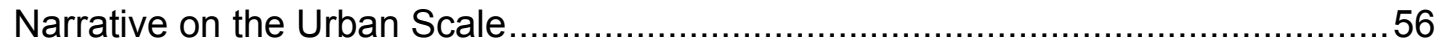

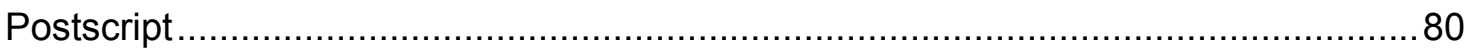

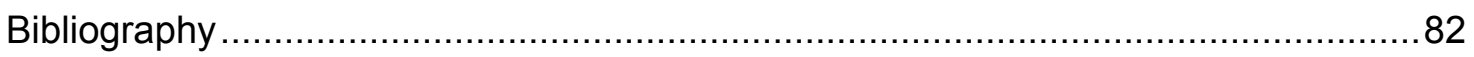




\section{List of Illustrations}

Figure 1. Thesis project by Daniil Makarov (Orthodox Christian monastery complex).....6

Figure 2. Symbolic meaning assigned to the spatial articulation of the church building .15

Figure 3. Symbolism expressed through the combination of geometric shapes in the

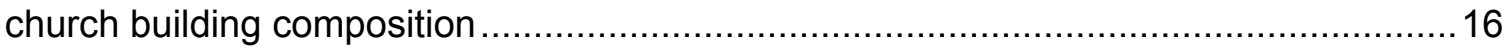

Figure 4. Russian Cultural and Spiritual Center - project by Manuel Nunez-Yanovsky .28

Figure 5. Russian Cultural and Spiritual Center - project by Jean-Michel Wilmotte .......28

Figure 6. Alexandre Nevski Cathedral, 12 Rue Daru, Paris .......................................29

Figure 7. Russian Cultural and Spiritual Center - competition entry by Mikhail Filipov ...29

Figure 8. Russian Orthodox Christian Church in Paris - eco-architecture in church design

Figure 9. Tree trunk incorporated in the church building - eco-architecture in church

design 30

Figure 10. Bioscleave House (Lifespan Extending Villa). East Hampton, New York, 2000-2008 39

Figure 11. Bioscleave House 39

Figure 12. Reversible Destiny Lofts. Mitaka, Tokyo, Japan Completed October $2005 \ldots 40$

Figure 13. Reversible Destiny Lofts 40

Figure 14. Site of Reversible Destiny. Yoro, Gifu Prefecture, Japan, 1993-1995 41

Figure 15. Reference project - Refectory Church in the Monastery of the Caves (Kiev

Pechersk Lavra) in Kiev, Ukraine

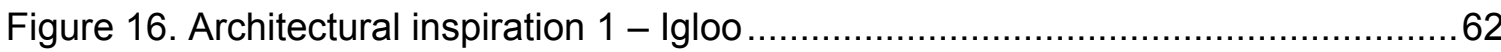

Figure 17. Architectural Inspiration 2 - Longhouse 62

Figure 18. Geometric composition of the church spaces - narrative in form of the spatial articulation 63 
Figure 19. Proportional composition of the church building geometry (the golden mean)

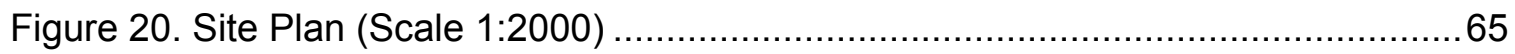

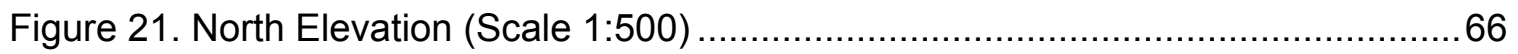

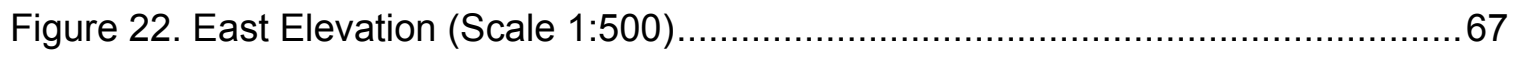

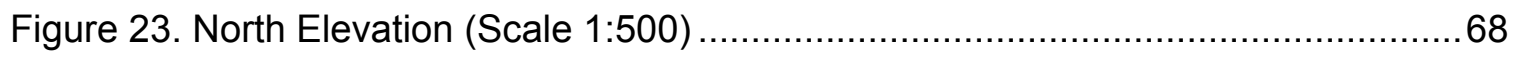

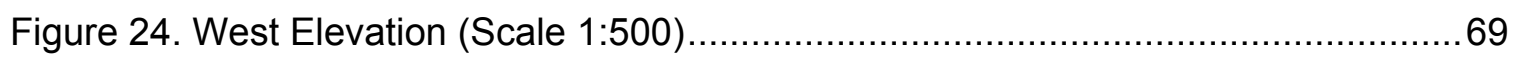

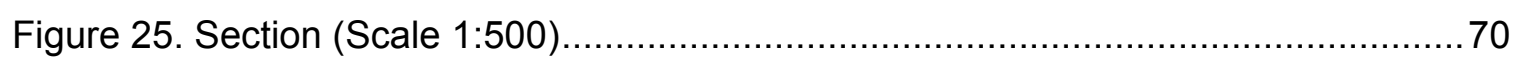

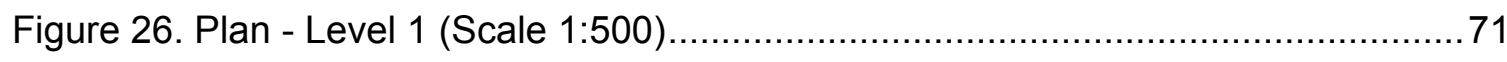

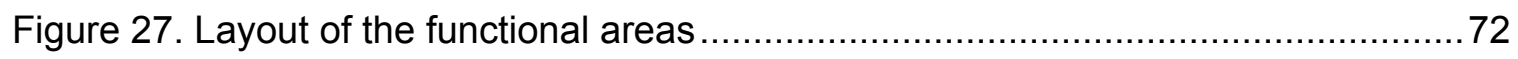

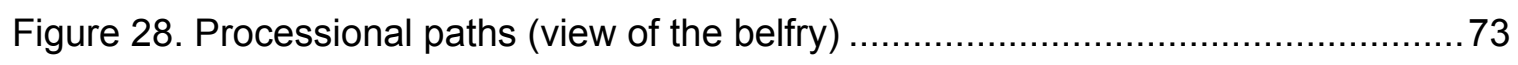

Figure 29. Arrangement of windows: random on outside, balanced and symmetrical on

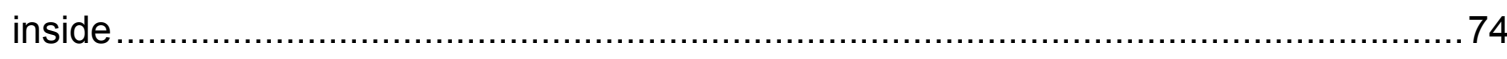

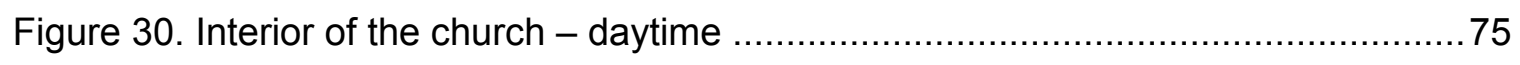

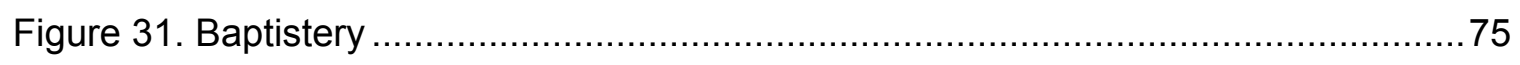

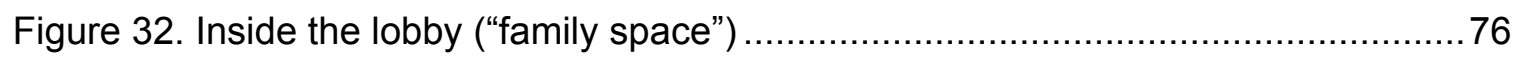

Figure 33. Interior walls with carved monochrome icons - tactile environment .............76

Figure 34. Changes in the building manifestation on site (subtle presence, rainbow

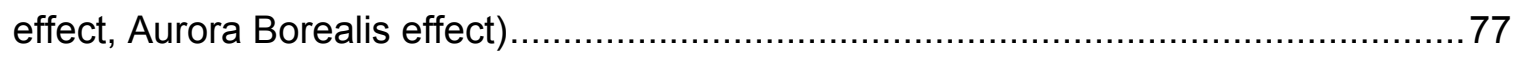

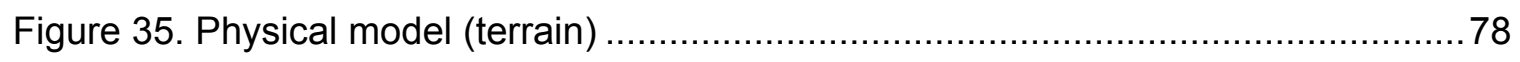

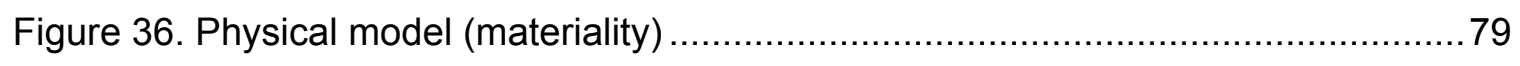




\section{Introduction}

The objective of the thesis is to establish an approach to the conceptual design of a contemporary Orthodox Christian church in order to accommodate its functions and to create its architectural image. The approach is based on the fundamental architectural design principles and is consistent with the Vitruvian triad ${ }^{1}$. The approach aims at creating an environment for an event to take place rather than at creating an architectural artifact: in this case, focusing on creating an environment for the Liturgy to be served, as opposed to creating an architectural signifier of a particular denomination in an urban setting.

The practical need for the creation of such an approach is dictated by the challenges architects face when they design a contemporary Orthodox Christian church. The current social, urban, and architectural conditions for such design are drastically different from those of the previous eras. The architectural narrative inherent to the church building has to be "translated" in order to address the cultural diversity, and to convey the harmonious and hierarchical architectural symbolism of the theological concept of the "transfigured world" in the context of unstructured urban surrounding. Existing guidelines and building codes do not adequately address the conceptual design method for such a complex and symbolic built form. At the same time, not all the "languages" from the broad palette of contemporary architectural expression are suitable for conveying the message embodied in the Orthodox Christian church building. The multifaceted issues of the contemporary church design are illustrated in the criticism of the precedent: architectural projects submitted for the competition for the Russian Cultural and Spiritual Center in Paris, France (2011).

\footnotetext{
${ }^{1}$ In the context of the thesis the Vitruvian triad will be understood as "Structural integrity, Usefulness, and Beauty"
} 
Regardless of various possible forms and context of the contemporary Orthodox Christian churches, the architects should have a general approach to designing such a complex architectural object whether it is a new building or an urban renewal project. The components of the design approach include: the outline of the meta-function (or the essential purpose) of the building; the definition of the dweller and the context, as well as the environment created by the built form. The proposed approach provides a framework for accommodating the new functions and creating the new image of the contemporary Orthodox Christian church, while implementing the design traditions of other cultures and taking advantage of new architectural styles and construction materials. The approach is supplementary to the current guidelines for the church design and construction, as well as traditional conceptual design methods of attributing symbolic meaning to the church building. The implementation of the approach is demonstrated with the thesis project - the design of the church titled "Holy Wisdom" in the downtown of Ottawa, Canada. The thesis project follows similar requirements and general cultural context as the precedent.

The thesis researches the current state of the sacred architecture industry in Eastern Europe, where in the past two decades there is the active construction of the places of worship and the active search for the new design methods for Orthodox Christian architecture. The thesis is meant to create an input in this search. 


\section{Issues and Challenges of the Contemporary Designing and Building of Churches}

In the past centuries, sacred architecture was the focal point of a European settlement. In a city or town, a cathedral was located near the main public gathering space or at the point of convergence of the main streets. In villages, a church would also be prominently featured in the landscape. Often church buildings were also the largest and the tallest structures in the settlement, and, therefore, were easy to locate.

The contemporary architects designing any sacred architecture have to respond to a different urban and cultural context. The sacred architecture in most cases is placed in a diverse community within densely built up urban environment, where skyscrapers exceed the height of any cathedral, and which does not allow the creation of a landmark the way it was done by previous generations. Responding to the urban context " $\ldots$ is complicated by the fact that the need for harmony must be reconciled with the desire for a building to resonate with particular purpose, and enclose a sense of physical and spiritual retreat from the urban fray. ... It is often almost impossible for architects to derive a harmonious link with the physical environment due to the inherent disharmony of the cityscape" (Richardson 2004, 63).

Orthodox Christian church building industry in Eastern Europe faces additional challenges when it comes to design and construction of places of worship. As described by architect Andrey Anisimov, the major problem of the contemporary Orthodox Christian church design in Russia is that after the seven-decade interruption in church design development the current generation consists of inexperienced architects and clients who do not have an understanding of what the church should look like and how it should be designed (Leontyev 2013). 
Architects are often unaware that the interior and exterior of the church, as well as the elements of interior décor, have to be designed in close coordination with each other. The design of church roof and ceiling topography has to be coordinated with iconographers, who will create the concept for their frescoes. Also during the seventyyear interruption in church design development many techniques of design and fresco painting have been lost.

Furthermore, the new materials do not behave in the same way as the ones used in traditional designs. As a result, the church community complains of the building having inadequate climatic control, bad acoustics and condensation on the concrete walls.

In general, the clients' idea of a future building is based on stereotypes, rather than on preferences. However, the attempt to imitate brick vaults with concrete, the use of false marble and titanium nitride instead of gold to imitate the splendor of the churches built by previous generations is not suitable for the contemporary church design: even the affordable, but quality materials can be used to create a true work of art.

Also, most of the issues arise when contemporary architects do not get a chance to become familiar with the heritage of the Orthodox Christian church design and rediscover the building and painting techniques, due to the fast-paced work environment.

Anisimov also stresses that artificial search for novelty in architectural design is not the right way for the development of church architecture (Leontyev 2013).

The general trends of church building development in Russia (and other Eastern European countries that share similar historical and cultural background, such as Ukraine, Belarus, etc.) can be generally divided in two categories: the emulation of historical styles to various degrees and complete departure from tradition (Shangin 2014) that produces a church building that is unrecognizable to the community. The first 
trend involves the copying of historical prototype, combinations of historical prototypes or attempts to create something new based on traditional and historical forms. The churches designed in such way do not represent our era and do not respond to the needs of the community. For example, a refectory church in a city center is no longer used for community meals. As for the second trend in church design, the attempt to follow the current architectural styles without regard to Orthodox Christian church design principles is criticized for creating a space where the believers have difficulty concentrating their minds, because the harmonious and predominantly symmetrical church interior is interfered with prominent gestures characteristic of contemporary architectural styles, such as random arrangement of windows (Ostrovsky 08). (Figure 1)

Previously the church design has always been in the avant-garde of architecture and the development in the church design was later used for secular architecture. At this point in time architects are facing challenges of responding to different cultural and urban conditions, as well as developing new expressions for churches provided by contemporary architectural styles and new building materials.

Anna Chukina (the curator of the Moscow Museum of Modern Art) discusses the use of the old and new materials in the church building and points out that the materials themselves are neutral, and it is their usage that renders them right or wrong in a given situation. For example, concrete that imitates another construction material is not authentic, while the concrete construction that is true to the material's nature is. The new materials create new architectural and artistic expression, and the architects and iconographers should not overlook the new artistic opportunities the materials can provide. An iconographer's or fresco painter's challenge is to create an image of spiritual 
world ${ }^{2}$ using any construction and art materials, regardless of whether they are traditional or newly invented (Chukina 2012, 67).

Probably the same can be said about the architectural styles used for church designs.

The new materials would require some time before they can be implemented since the architects and iconographers will have to develop the techniques for their use and combination with other materials. As for the new architectural styles, they can be implemented right away, in case the resulting building is consistent with the guidelines for Orthodox Christian church design.

After all, it does not matter whether the church design is traditional or new, but rather is it true or false in its representation of the spiritual world (Ostrovskiy 2013).

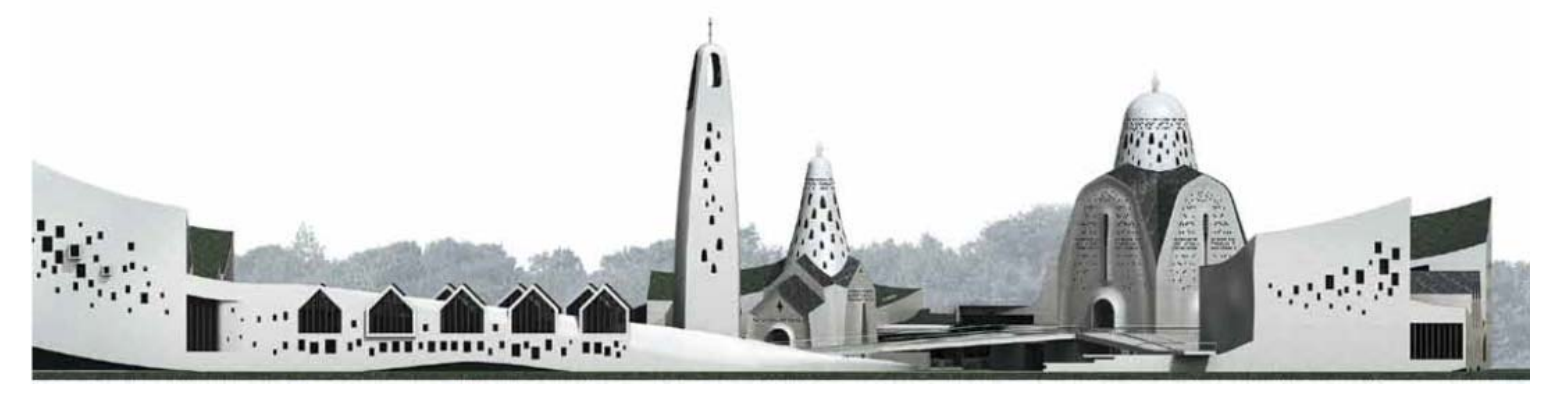

Figure 1. Thesis project by Daniil Makarov (Orthodox Christian monastery complex)

${ }^{2}$ As expressed by Leonid Ouspensky, the prominent researcher of the Orthodox Christian art: "the Church of Christ embodies both material and spiritual realms. The material realm is directly available to be perceived by our senses. The spiritual realm is represented by the means of symbolism." 


\section{The Symbolism of the Orthodox Christian Church}

Based on the research of multiple sources ${ }^{3}$ the Orthodox Christian church design is created in accordance with the following architectural principles: self-sufficiency of the church building and its uninterrupted compositional connection to the sky; harmony, hierarchy, beauty, authenticity of the design and its constant reference to the traditions.

The church building is a complex symbol, which is integrated into the Orthodox Christian system of symbols that create the environment for performing the liturgy. This system consists of interrelated layers of symbolism expressed in architecture, interior design, visual arts, music, poetry (liturgical texts), the design of the vestments of the clergy, etc. The architectural layer of the church symbolism consists of the arrangement of functional

${ }^{3}$ Sources:

Kesler, Mikhail. 2013. "Temple Architecture: Features, Meanings, Objectives (Храмовое зодчество: особенности, смыслы, задачи)." Храмоздатель (Temple Builder) 12-20.

Kesler, Mikhail. 2015. "Объемно-планировочные [Space-Planning Solutions of Orthodox Christian Temples]." (2).

Baidine, Valery. 2012. O novom obraze russkogo hrama. Russkiy Hram: XXI vek. [On the New Image of the Russian Temple. Russian Temple: 21 Century]. Translated by Translated by Author. Accessed 11 16, 2015. http://www.archi.ru/lib/e_publication_for_print.html?id=1850569920.

Centre of Architecture and Art of the Moscow Patriarchate. 2003. "Православные храмы. Пособие по проектированию и строительству к СП 31-103-99 [Orthodox churches. Manual for the design and construction to SP 31-103-99]." Православные храмы и комплексы [Orthodox churches and complexes]. Vol. 2. Compiled by Mikhail Kesler. Moscow: Гуп Цпп.

—. 2004. "Православные храмы. Пособие по проектированию и строительству к СП 31-10399 [Orthodox Temples. Manual for the Design and Construction supplementary to SP 31103-99]." Примеры архитектурно-строительных решений [Examples of architectural solutions]. Vol. 3. Compiled by Mikhail Kesler. Moscow: Гуп Цпп.

—. 2003. "Православные храмы. Пособие по проектированию и строительству к СП 31-10399 [Orthodox churches. Manual for the design and construction to SP 31-103-99]." Православные храмы и комплексы [Orthodox churches and complexes]- Ideya i Obraz [Idea and Image]. Vol. 1. Compiled by Mikhail Kesler. Гуп Цпп. 
spaces and passages between them, the tectonic and volumetric articulation of the church building, and the overlay of the pictorial representation on the building surfaces.

The Orthodox Christian church designs do not adhere to strict rules and are not based on ancient and "eternal" archetype. At the same time, these designs are not completely limitless in their architectural expression, as it is the case in the church construction for Western Christian denominations in the 20th and 21st centuries.

The design of the Orthodox Christian church is not determined by any written rules. However, it is defined by the canonical tradition, where the succession of the architectural development of the church building is evolving with reference to prototypes, which were accepted by the Church, as the expression of the Orthodox Christian concepts in built form. The prototypes used in the canonical tradition of the church design only have an educational function to help the architects acquire an understanding of the church design while allowing them to use their creativity in the design development

The only design aspect that remains strictly canonical is the separation of the altar and the nave by the means of the iconostasis.

Despite the absence of written rules for the church design the succession of the design development is maintained. The symbolism of the Orthodox Christian church creates a framework for the image of the building to remain recognizable and the rite to remain unchangeable despite the great variety of the design solutions of the churches that have evolved over the centuries.

To maintain the succession in the design tradition the architects rely on immutable architectural principles, which are used to convey the meaning of the church. Being a complex symbol, the church embodies many meanings, the most important of which is a 
representation of the transfigured world (the Kingdom of God), the embodiment of the essence of the Orthodox Christian faith, and the convergence of human and divine.

\section{The Architectural Principles}

The conveying of the meaning relies on the use of immutable architectural principles, such as: self-sufficiency of the church building and its uninterrupted compositional connection to the sky; harmony, hierarchy, beauty, authenticity of the design and its constant reference to the traditions.

\section{The Church Is Self-Sufficient}

The church building is self-sufficient, and the interior space of the building is of primary importance to its outward appearance.

\section{The Compositional Connection to the Sky}

The church cannot be separated from the sky in any way, either structurally or visually. The vertical axis, which represents the connection between heaven and Earth, is at the center of the architectural composition of the church. The main dome with the cross is the highest point of the church composition and completes the vertical axis (Figure 2).

\section{Harmony}

The architecture of the church is based on the proportional relationship of the respective parts and to the whole. The decorative elements play a secondary role.

The architectural composition of the church is usually symmetrical; however the asymmetrical compositions can also be used if the condition of the site or creation of a particular architectural image requires it. Nevertheless, the prominent asymmetry of the structure, similar to the designs of certain secular buildings is not recommended. 
The asymmetrical elements may be present if they are subordinate to the main idea of balance and order, which is meant to convey the image of the transfigured world ${ }^{4}$.

The articulation of the internal space based on the harmonious balance of the two axes: the horizontal (East - West) and vertical (earth - sky).

The harmony is also expressed through the combination of geometric shapes that convey a specific meaning, for example, the connection between Heaven and Earth realm (combination of top circular dome and cube of the nave).

The proportions and volumes of the church should be harmonious in all architectural schemes, the internal and external spaces should complement each other stylistically, the details cannot contradict to the whole, the interior space should be organized hierarchically from top to bottom: from the cupola to the floor area.

\section{Hierarchy}

In the building interior, the highest importance is assigned to space under the dome (or the domes).

The horizontal hierarchy is expressed through constancy of the relation of the functional spaces: the sacred spatial organization of the church should remain unchanged: the traditional location of the cross and the dome (or other tops), the entrance gates, the pulpit, the iconostasis and the eastward oriented altar. The altar is always higher than the nave, and the nave is usually higher than the other functional spaces.

\footnotetext{
4 "The Orthodox Christian church in general represents the entire universe. It is the image of the world, renewed and transformed cosmos, the restored image of universal unity, which is opposed to the universal discord and animosity among the creatures. It is the world, built into the church building and completed with the head -Christ." (Ouspensky, Vopros ikonostasa. [the Question of Iconostasis] 1992)
} 
The location of the pictorial representations in the form of frescos and mosaics on the church walls and ceiling topography is arranged hierarchically according to the importance of the subjects represented. The colour scheme for the images is darkest at the lower level and becomes progressively lighter upon its ascension to the higher levels of the church interior. The lightest and the most important images are located under the domes with the image of Christ the Pantokrator at the ceiling of the main dome of the church.

Exterior decoration of the church is closely related to the interior decoration, creating a prelude to the interior. Also, the pictorial representations on the facades of the churches are addressed to the urban surroundings and are meant to be perceived by people, who are passing by the church or are approaching it.

\section{Beauty}

The church is designed to embody beauty conveyed through all the possible artistic and architectural means since the immutable beauty is as an expression of the divine.

The artistic representation of the spiritual beauty in the church building, which is a reflection of the beauty of heavenly Kingdom, is separate from the secular notion of aesthetics that is subject to change according to the preferences of an era.

The church should use the best available materials and the best current construction and decoration techniques.

The ornamentation is not essential for the church, and the building without ornaments can still express beauty through other means, such as the use of harmonious proportions, light, inherent beauty of simple natural materials, etc. 


\section{Authenticity}

The principle of the authenticity of the church is expressed in many ways. The architectonics of the church buildings, their acoustics, building technology, materials used, their texture, colour, etc. must comply with the liturgical purpose of the church, to create "aura" of authenticity and uniqueness.

The art and construction materials in the church building have to be used according to their actual qualities, as opposed to mimicking the appearance of other materials. For example, concrete should not represent marble if real marble cannot be used.

\section{Succession of the Tradition}

The Orthodox Christian church represents the spiritual world and conveys the essence of the faith through the means of images, materials, and colours. Its form and arrangement are related to its content and, therefore, cannot be deliberately altered. However, they can be interpreted within the framework of the Orthodox Christian concepts.

The sacred spatial organization of the church should remain unchanged: the traditional location of the cross and the dome (or other tops), the entrance gates, the pulpit, the iconostasis and the eastward-oriented altar.

The constancy of Orthodox Christian belief and rite determines the immutability of the church organization. Consequently, the architecture of the church and the symbolism of the architectural forms, which reflect the unchangeable Orthodox Christian teaching, are constant and traditional in essence.

There is certain variety in the architectural design of the church in various cultures, which is influenced by local climatic conditions, historical development, and national 
traditions. However, these variations do not affect the core principles of the church design.

In any country and at any time the Orthodox Christian faith remains the same. The church architecture is not based on any architectural or ethnic style. Consequently, the new developments in church architecture did not change the buildings radically and did not reject the previous developments, but rather built upon the previous ones.

The church buildings are designed to last for ages, and, therefore, the materials, technologies and building construction techniques used for them have to be durable.

\section{The Architectural Design Components and Their Combinations}

In addition to the application of the architectural principles, the symbolism is attributed to the church through the use of architectural design components, many of which have evolved as a part of regional tradition, but also acquired a theological meaning.

The main formative symbols of the Orthodox Christian church, which convey the concept of Christ's Church, are a square, a circle and a triangle, as well as their volumetric models - a cube, a sphere, and a pyramid (Figure 3). The square and the cube symbolize the material and temporary world, the Earth; the circle and sphere - the spiritual world, the divine, eternal; triangles and pyramids - a geometrical shape of inversion "linking" the two worlds - the material and the spiritual.

The plans of the churches are traditionally rectangular, round, octagonal or cruciform. The middle part of the church can also be divided by pillars into several isles. As a rule, the size of the central nave is greater than the sizes of the aisles. 
The traditional roof configurations of the Orthodox Christian churches can be domed, vaulted, tented, kokoshnik-style (with exterior layers of faux vaults, similar to traditional Russian headdress), tiered and gable.

The church is crowned with domes of onion shape, helmet shape or other shapes with the cross on top. The traditional number of domes on the churches is usually $1,3,5,7$, or 12. However, a different number can be used. The numbers of the domes have the following symbolic meanings: 1 - the Christ; 3 - the Holy Trinity; 5 - Christ and the four Evangelists; 7 - seven ranks of angels, the seven sacraments, the seven Ecumenical Councils; 13 - Christ and the 12 apostles, etc. As a rule, the quantity of the domes crowning the church is no less than the quantity of the altar tables in the church.

The plans of the churches are traditionally rectangular, round, octagonal or cruciform. The middle part of the church can also be divided by pillars into several aisles. As a rule, the size of the central nave is greater than the rest.]

\section{Pictorial Representations}

Another layer of symbolism in the Orthodox Christian church takes the form of pictorial representations that overlay the interior and exterior of the church and are integrated into the church's functional décor.

The pictorial representations used in the Orthodox Christian churches are either in form of individually painted icons that are brought into the church (placed in the interior and incorporated in the iconostasis) or in form of the frescoes and/or mosaic. The latter are located in the interior of the church (on the walls and ceiling topography) and sometimes on exterior as well.

The sacred images used in the pictorial representations are perceived as a reflection of the ideas. An icon can be compared to a book written with visual images. An icon is 
different from a painting because it does not represent a specific event in history attached to the specific place and time. The icon does not embody the immediate emotions of participants of events, and captures the essence, the meaning of the event, as if extracting it from the realm of time and space.

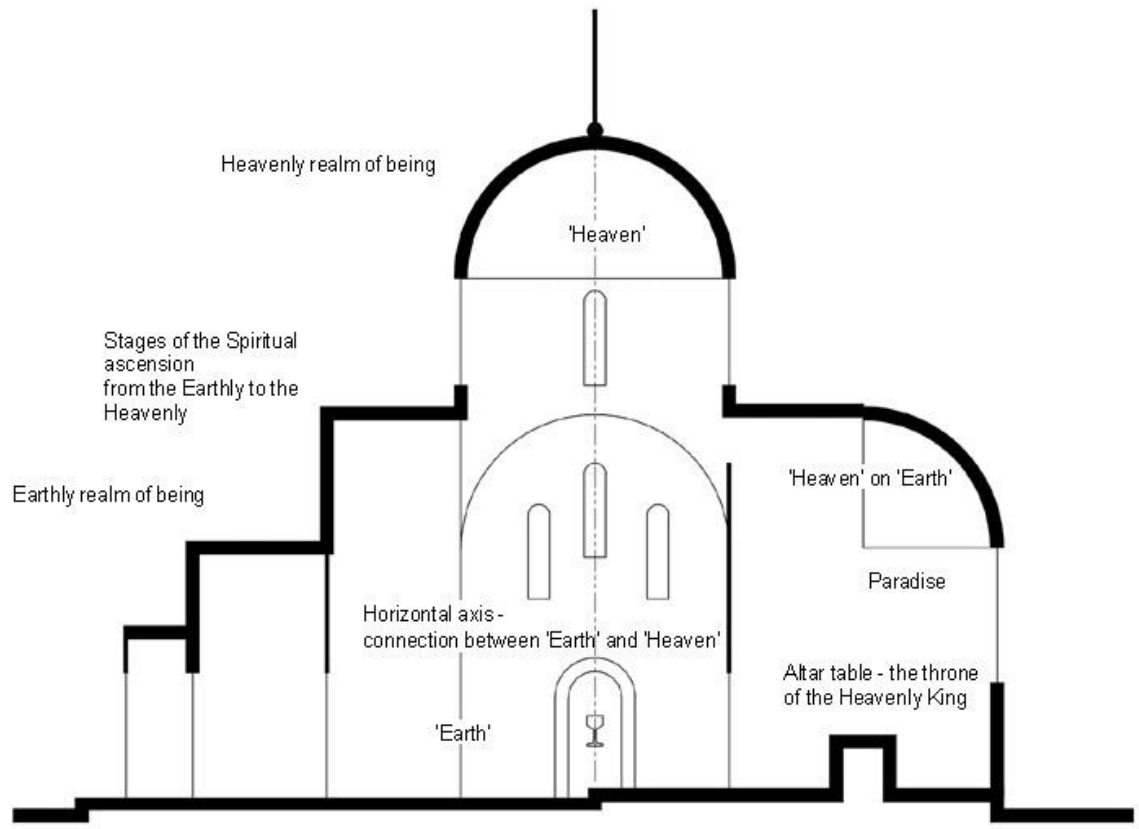

Ambon - meeting point between 'Heaven' and 'Earth'

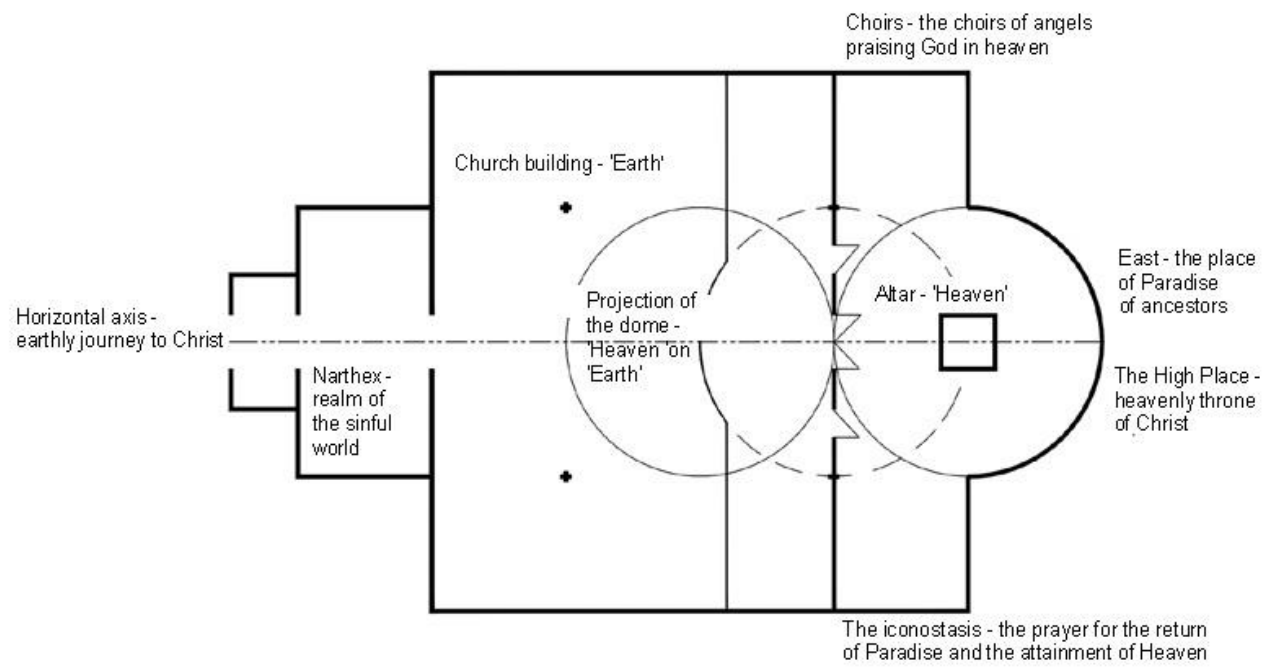

Figure 2. Symbolic meaning assigned to the spatial articulation of the church building 


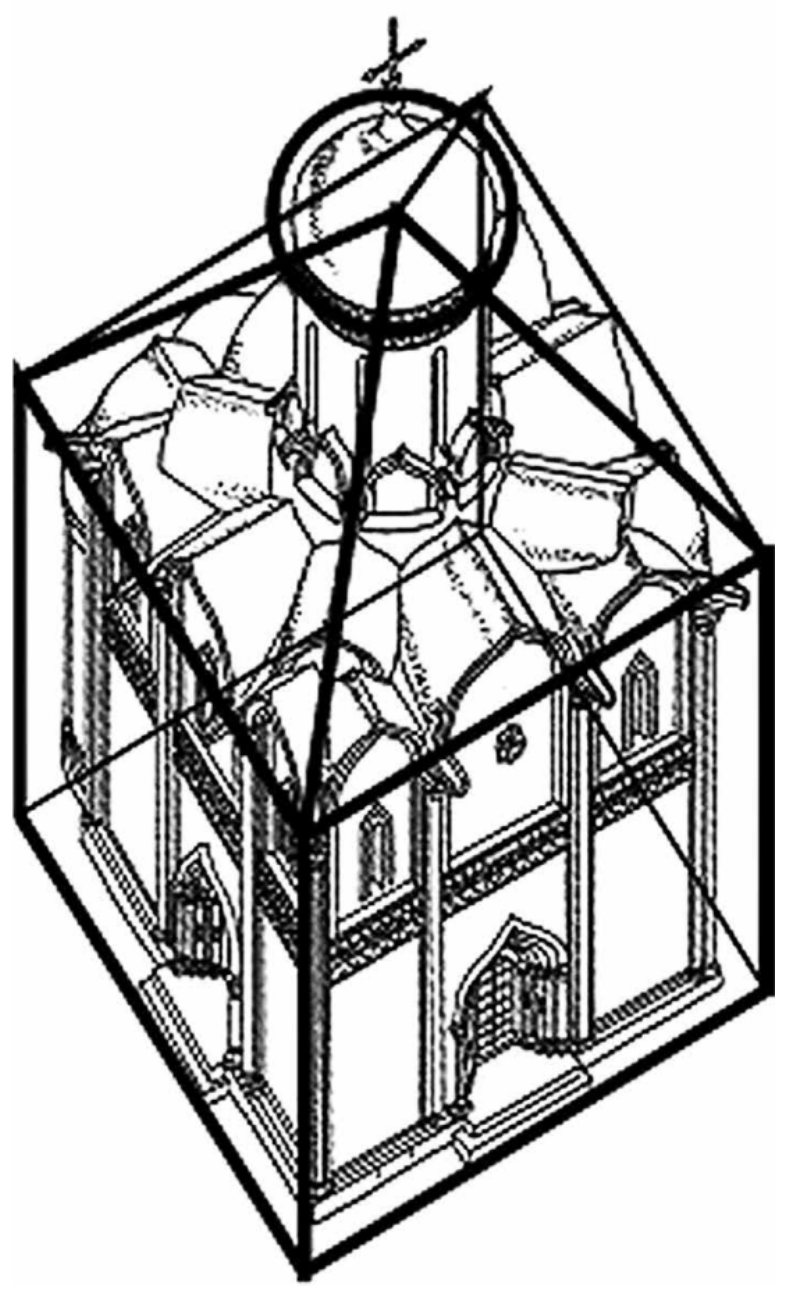

Figure 3. Symbolism expressed through the combination of geometric shapes in the church building composition 


\section{General Guidelines for Design and Construction of Contemporary Orthodox Christian Churches}

The current Orthodox Christian church construction standards and a research of contemporary design practices of church building ${ }^{5}$ provides the following general guidelines for the design and construction of a contemporary Orthodox Christian church.

\section{Functional Classification}

The main function of all the Orthodox Christian churches is serving a liturgy. However, they can be divided into several groups, in which the differences in their spatial articulations are related to their functional features, including the presence of various auxiliary facilities.

There are three major types of the contemporary Orthodox Christian churches: cathedrals, parish churches, monasteries. There are also many other types, such as memorial churches, house churches, churches at institutional buildings (hospitals, schools, and factories), mobile, and ordinary churches.

${ }^{5}$ Sources:

Centre of Architecture and Art of the Moscow Patriarchate. 2003. "Православные храмы. Пособие по проектированию и строительству к СП 31-103-99 [Orthodox churches. Manual for the design and construction to SP 31-103-99]." Православные храмы и комплексы [Orthodox churches and complexes]. Vol. 2. Compiled by Mikhail Kesler. Moscow: Гуп Цпп.

—. 2004. "Православные храмы. Пособие по проектированию и строительству к СП 31-10399 [Orthodox Temples. Manual for the Design and Construction supplementary to SP 31103-99]." Примеры архитектурно-строительных решений [Examples of architectural solutions]. Vol. 3. Compiled by Mikhail Kesler. Moscow: Гуп Цпп.

—. 2003. "Православные храмы. Пособие по проектированию и строительству к СП 31-10399 [Orthodox churches. Manual for the design and construction to SP 31-103-99]." Православные храмы и комплексы [Orthodox churches and complexes] - Ideya i Obraz [Idea and Image]. Vol. 1. Compiled by Mikhail Kesler. Гуп Цпп.

Kesler, Mikhail. 2015. "Конструктивные решения и строительные материалы [Design Solutions and Building Materials]."

Kesler, Mikhail. 2015. "Объемно-планировочные [Space-Planning Solutions of Orthodox Christian Temples]." (2). 
The most common type is a parish church.

\section{Spatial Articulation}

Architectural design and spatial composition of the church should be subject to the canonical order of Orthodox Christian worship, to ensure uninterrupted movement of the clergy through the church interior and around the building, as well as proper setup to ensure that the parishioners can hear and see the liturgy well.

As a rule, the Orthodox Christian church consists of three main parts: the altar, the nave (the actual "church" or room for prayers) and the narthex. The church may consist of a single room divided by a partition (i.e. iconostasis) in two parts: the actual church and the altar, which can be used only by clergy.

Depending on the size and the functional features the churches can have single or multiple parecclesions (or chapels) with different dedications to allow multiple services to be served simultaneously. The parecclesions can be contained within the main volume of the church or be attached to it. The parish churches are usually single-story, but they may also have two stories or a basement.

\section{Capacity and Occupancy}

The capacity of the churches is determined based on the size and demographic makeup of the population. The parish churches, located in the cities accommodate from 450 to 1,500 people. In small towns, parish churches accommodate 50 - 100.

The capacity of the church determines its size, spans between supports, the number of floors, aisles, chapels, domes, etc. If the church accommodates up to 300 people, it has only one altar. Depending on the size of the church, 70 to $90 \%$ of the area in the nave is used to accommodate the parishioners. 
It is recommended to calculate the occupant load of the church using the load factor of three persons per one meter squared of space excluding the areas where people do not stand during the services. Such spaces include: the seating for those parishioners, who cannot remain standing during the services; areas around the furniture (candle stands, lectern, etc.) and other objects in the church (placed along the walls and around the pillars).

\section{Combination with Other Buildings of the Church Complex}

The architectural design solutions of the church are also affected by the following:

A combination of the church with a belfry, especially if the belfry is located in the main dome of the church;

A combination of the church with an auxiliary space, located in the basement of the church or the basement under a gallery;

A combination of a complex of buildings with auxiliary facilities: the house of the clergy and other buildings.

\section{Accommodation to Urban Surroundings}

Architectural design solutions, including the architectural composition of the church, are formed depending on the conditions of the urban environment and the church's location: whether the church is built in the open air on a square or within a block of urban development. In the first case, the building elements are composed around a center, in the second case, it is more common to have the longitudinal arrangement of the individual parts of the church or any other arrangement defined by the configuration of the site. 
The current issue of accommodating the functions of the church complex in a contemporary urban setting requires a new architectural design solution: containing a church and its auxiliary spaces in a single building volume on a small site. Previously the church and its auxiliary buildings, such as parish school, daycare, etc. were arranged on a plane in the vicinity of each other in form of a small village. Currently, the sites provided for the construction of the churches in the urban setting are too small to accommodate such arrangement, and, therefore, the church, and its auxiliary spaces have to be arranged vertically. This type of architectural church design is unknown to the Orthodox Christian church building tradition and cannot be implemented using old architectural forms. The accommodation of the new content requires the development of the new building composition.

\section{The Climatic Conditions and the Requirements for Creating Favorable Sanitary}

\section{Conditions}

For the northern regions, with low temperatures, wind, and snow drifts, architectural design solutions should be oriented to creating the conditions for heat conservation: a compact volume with minimal external surface area, corresponding thickness of the walls, the shape of the roof, and the materials used. For the southern regions, where the issues of thermal insulation are not as severe, it is possible to employ the widespread use of concrete and, as a result creating more opportunities to form spatial plasticity.

To ensure favorable conditions for the microclimate inside the church HVAC systems are used nowadays.

\section{National or Regional Traditions}

National or regional traditions were formed mainly on the basis of socio-economic and climatic conditions, as well as the availability of certain building materials. Even with the 
changing socio-economic situation and the emergence of the opportunity to use any imported materials, the focus on the established design solutions nevertheless remains a factor that has to be taken into account.

\section{The Common Building Materials}

Currently, brick, wood, and concrete are the main materials chosen for the construction of the Orthodox Christian churches. These materials can be used in all construction components of the structure or combined with each other. The use of brick in the walls and the roof structure results in limited spans, the massiveness of pillars and exterior walls.

Architectural design solutions of wooden churches are dictated by the limitations of the lengths and configurations of the walls, which are defined by the by the dimensions of logs.

Reinforced concrete structures can create a surface of any shape and large enough to accommodate slab spans. However, the heat-resistance characteristics of reinforced concrete structures do not allow their use for the exterior walls without cladding. Thus, it is advisable to use concrete in structures and coatings in combination with the brick walls.

\section{The Preferences of the Client (Church Community), the Designer and the}

\section{Contractor}

Proposals on various parameters of architectural design solutions can come either from the client, the designer, or the contractor, since every party is involved in finding a common design solution of the church. 


\section{Supplementary Design Considerations}

Just like any other building, an Orthodox Christian church, has to be consistent with local building codes to ensure fire safety, accessibility and other provisions necessary for compliance with local by-laws and accommodation to local climatic, geographical, urban and social conditions. Such design provisions can potentially become complementary means of architectural expression in addition to the traditional symbolism of the Orthodox Christian churches. 


\section{Precedent - The Russian Cultural and Spiritual Center in Paris (2011)}

The challenges of creating an image for the contemporary Orthodox Christian church can be illustrated with the architectural projects submitted for the competition for the construction of the Russian Religious and Cultural Center in Paris ${ }^{6}$.

The Center has to be constructed on the 8500 square meter site located on the bank of the River Seine near the Eiffel Tower in the 7th district of Paris. The site that Russia purchased in 2010 was previously occupied by Meteo France buildings. The construction of the Center started at the beginning of 2014 is going to be completed in two years.

One of the main requirements for the design of the Center was to create a church building that embodies the synthesis of traditional and contemporary architecture. However, all of the projects selected for the final round of the competition, including the winning entries revealed the difficulty to generate such a synthesis. Consequently, they

${ }^{6}$ The project description and the competition facts are taken from the following sources:

Wilmotte \& Associés. n.d. Centre Spirituel et Culturel Orthodoxe Russe. Accessed 1 19, 2015. http://www.wilmotte.com/fr/projet/404/Centre-Spirituel-et-Culturel-Russe.

Sikhatova, Rusina. 2014. Le nouveau Centre spirituel et culturel orthodoxe russe présenté à Paris. 1 17. Accessed 1 15, 2015. http://www.lecourrierderussie.com/2014/01/centrespirituel-russe-paris/.

Lomholt, Isabelle. 2011. Russian Cultural Centre + Orthodox Worship, Paris. 3 24. Accessed 1 19, 2015. http://www.e-architect.co.uk/paris/russian-cultural-centre.

2014. История возникновения духовно-культурного православного центра в Париже [The Story of the Spiritual and Cultural Orthodox Christian Center in Paris]. 3 2. Accessed 12 15, 2014. http://kommersant.ru/doc/2396190.

Агентство архитектурных новостей [Architectural News Agency]. 2014. Еще раз [Once Again]. 1 18. Accessed 12 15, 2014. http://www.archi.ru/world/52596/obnarodovan-novyi-proektrusskogo-kulturnogo-centra-v-parizhe.

Sidelnikova, Maria, and Aleksey Tarkhanov. 2014. Храм неизвестного святого [Temple of an Unknown Saint]. 1 18. Accessed 12 15, 2014. http://www.kommersant.ru/doc/2387334. 
revealed the difficulty to create the image of the church that would naturally embody both the reference to the heritage of the previous generations and the distinct features of our era.

The international competition for the construction of the Religious and Cultural Center in Paris, dedicated to Orthodox Christianity and Russian culture, was held in 2011 and had 444 entries. The winner of the competition was the project by Manuel Nunes-Yanovski's Paris Bureau "Sade" (Figure 4), whose design was later substituted by Jean-Michel Wilmotte's (the second place winner) (Figure 5).

Nunez-Yanovski's project provoked a strong negative reaction both in Russia and in France. It was rejected on the initiative of the mayor of Paris Bertrand Delanoe at the beginning of 2012, during the process of negotiating with the prefecture. Yanovsky's five-domed church with a glass roof did not fit into the architectural ensemble on the quays of the Seine (which are under the protection of UNESCO). Also, the domes with crosses exceeded the allowable height, according to the Paris prefecture.

As the result, Russia withdrew a request for approval of the draft by Nunez-Yanovsky, and in February 2013 it was announced that Jean-Michel Wilmotte was invited to work on the project. The project acquired a new program and a new appearance. Wilmotte's design has passed all approvals and meets the requirements of town planning rules and the French legislation.

The building is going to be clad with Burgundy stone veneer. This material was used to construct the Louvre and Notre Dame and is often found on the facades of neighboring buildings of the prestigious 7 th district of Paris. The thin strips of stone form a loose grid, with the aim to dissolve the buildings in the air and make them less noticeable and more delicate. The height of the main cross is 35.85 meters, the height of the church and the 
other buildings of the complex- no more than 18 meters, which is consistent with the city's height restrictions. The golden domes will have a matte finish, unlike the shiny domes of the traditional designs that were meant to be seen from far away.

Yanovski's project highlighted problems that were present in nearly all the competition projects selected for the final round. The images created for the church buildings neither represented the synthesis of the contemporary and traditional architecture nor did they create a dialogue with the urban fabric of Paris. Yanovski's design drew criticism from two sides. On the one hand, the supporters of the construction of the conservative and traditional Russian church in central Paris criticized the novelty and the abundance of glazing. They have called the design "disputably new" and representative of "anonymous, soulless high-tech". On the other hand, the Russian architectural critic Grigory Revzin has analyzed the style and the circumstances of the project and identified it as post-modern, i.e. obsolete for more than thirty years. He also remarked that the project could be treated as another exhibit of the Ethnographic Museum in Paris, built a few years ago by Jean Nouvel in the vicinity of the site. The design featured the clash of historical artifact and the glazed roof similar to the portion of the façade of the museum (Tarabarina 2011).

The Orthodox Christian architecture that is evolving in Russia since the beginning of the 1990 's is incompatible with the notion of "contemporary architecture" since these two are in opposition to each other. The project in Paris was meant to embody "the synthesis of the national traditions and the ideas of the modern Western architecture", as expressed by Archbishop Mark, who is in charge of foreign institutions at Moscow Patriarchate. At this time, it is impossible because there has been no experience of such synthesis up to now (Tarabarina 2011). 
The typology of the church designs in most of the competition projects is inconsistent with the Parisian architecture and renders the new church a distinctly foreign object in the downtown of the French capital. The majority of the projects that were entered in the competition have used the "onion" domes to top the church building. Such roof design was not the most suitable design choice for a Russian church located in this particular area of Paris. The church buildings represented a historical artifact from a particular era of Russian history. The attempts to cover the church buildings from the surrounding streets, to reconcile them with the city, were evident in many of the competition projects, including the two winning entries. Many of the projects also incorporated elements of contemporary architecture that clashed with the historical emulations.

The following are the descriptions of other possible design choices, which could produce an image for a church building on this site that the contemporary Parisians could find recognizable and relatable. The tented domes, similar to the ones topping the historical landmark built in Paris in 1861 (Figure 6) (the Alexandre Nevski Cathedral on 12 rue Daru in the 8th district of Paris), would echo the Eiffel tower in the skyline of the Paris downtown. Also, they would represent the unique invention of Russian architecture: a tented dome. Another option for the Russian Orthodox Christian Church design that would be suitable for downtown Paris would be the creation of the building in Classicist style. Such design was exemplified in one of the ten final round competition projects designed by architect Mikhail Filipov (Figure 7). However, his project did not even attempt to generate the synthesis of contemporary and traditional architectural design. The eco-architecture would also be a suitable option. It may not be specifically tailored to fit the Paris urban fabric. Nevertheless, it would be consistent with the sustainability trend in contemporary architecture, as well as one of the important concepts of Orthodox Christian faith: celebrating God's creation - nature (Figures 8, 9). (Baidine 2012) 
Historian Valery Baidine notes that many people in Russia, from clergy to architects, have expected the emergence of new, bright, breakthrough ideas in church architecture in the course of this competition. They felt the need for the new inventions in the church design for a long time. However, he continues, "new ideas" in all ten final projects were either absent or were filled with postmodern aggression and arrogant ignorance of the very foundations of the Orthodox Christian architecture. (Baidine 2012) 


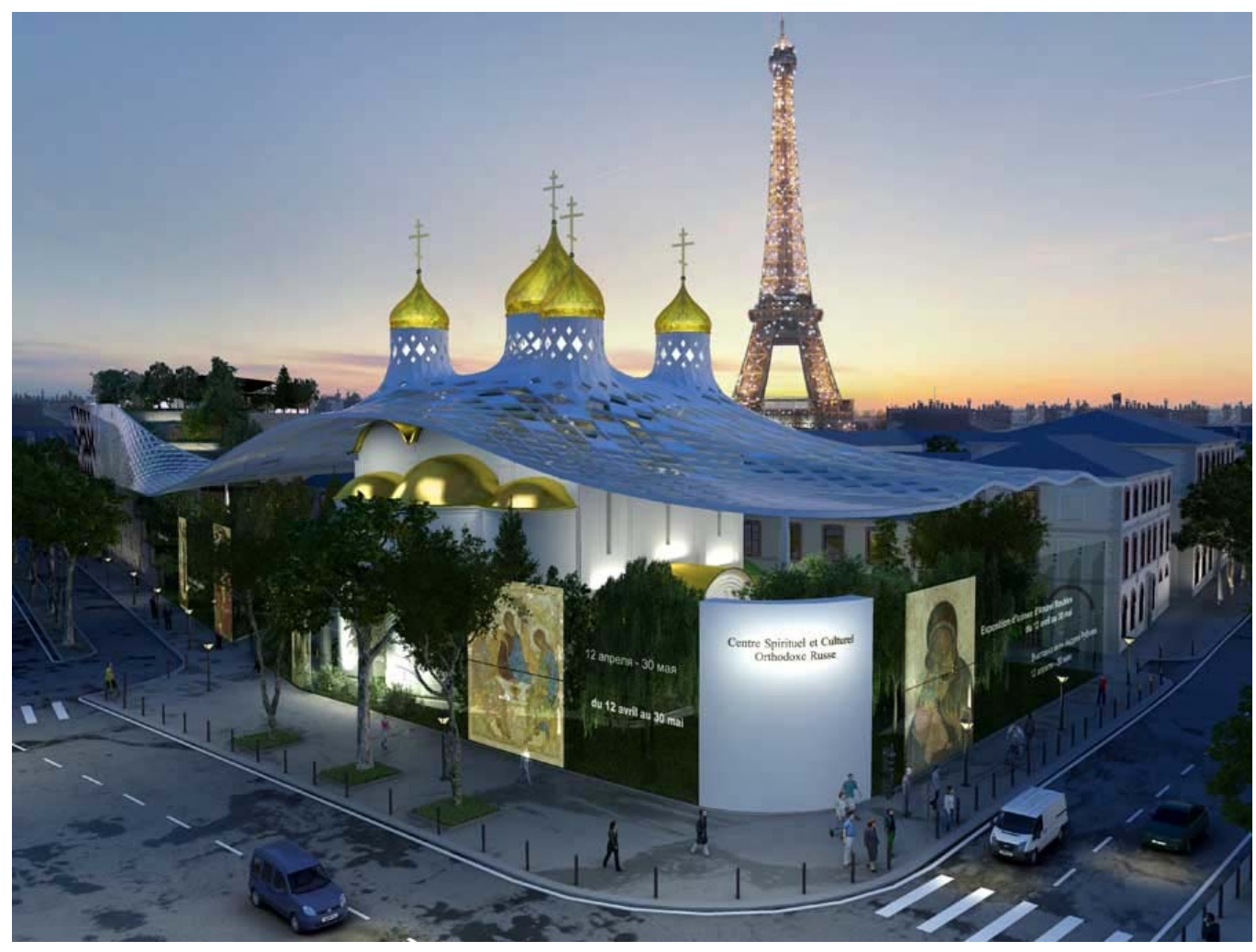

Figure 4. Russian Cultural and Spiritual Center - project by Manuel Nunez-Yanovsky

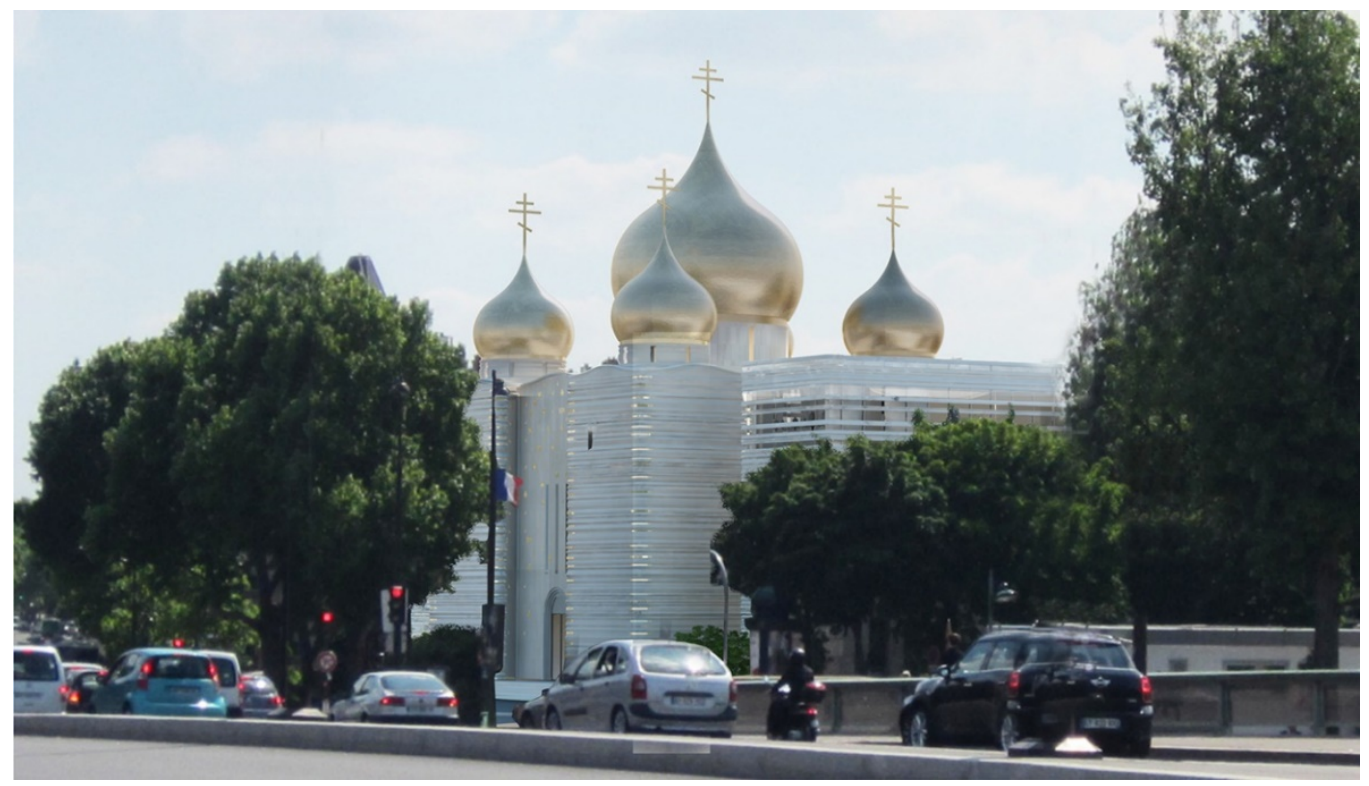

Figure 5. Russian Cultural and Spiritual Center - project by Jean-Michel Wilmotte 


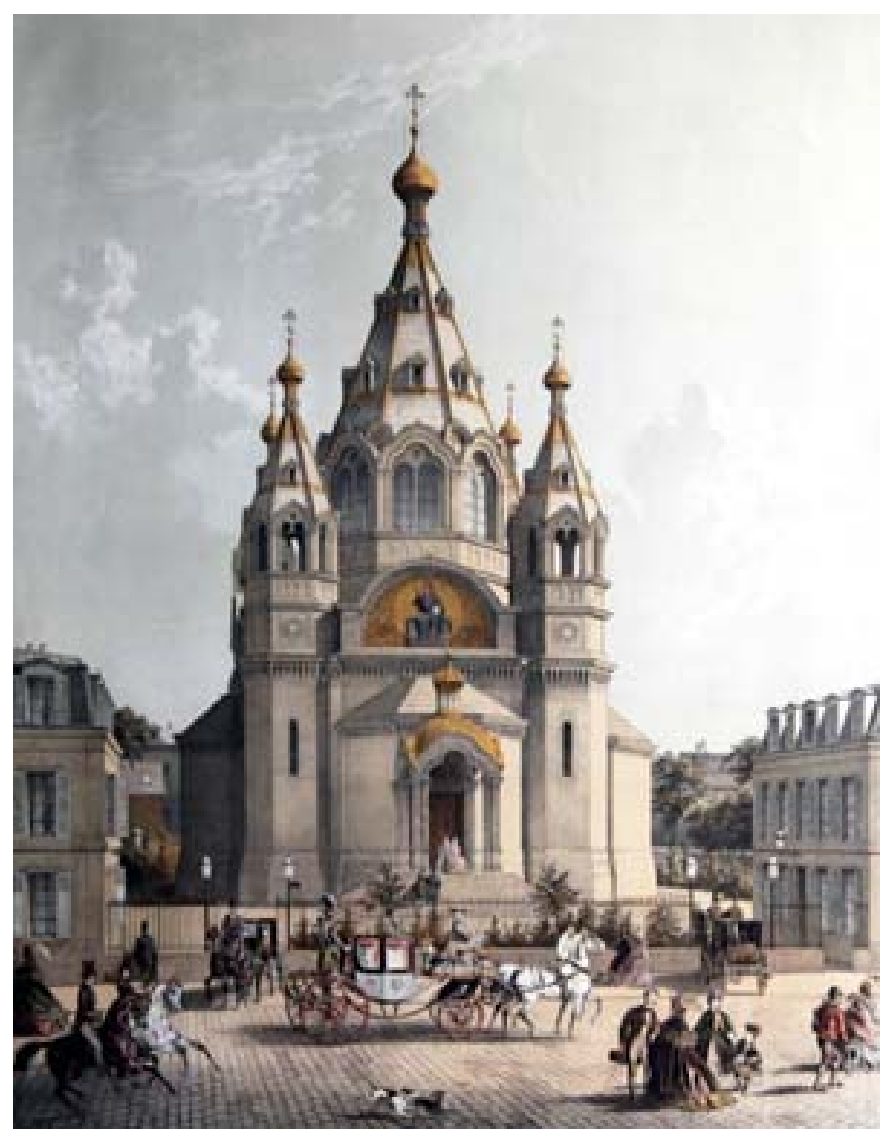

Figure 6. Alexandre Nevski Cathedral, 12 Rue Daru, Paris

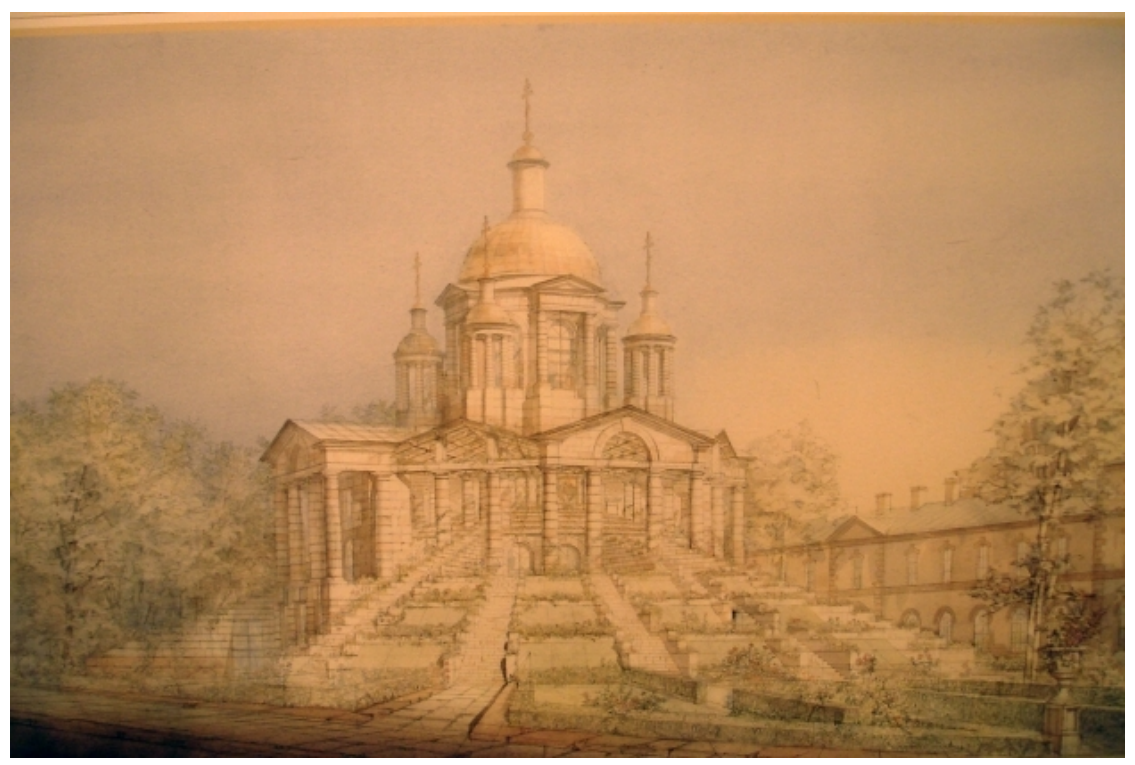

Figure 7. Russian Cultural and Spiritual Center - competition entry by Mikhail Filipov 


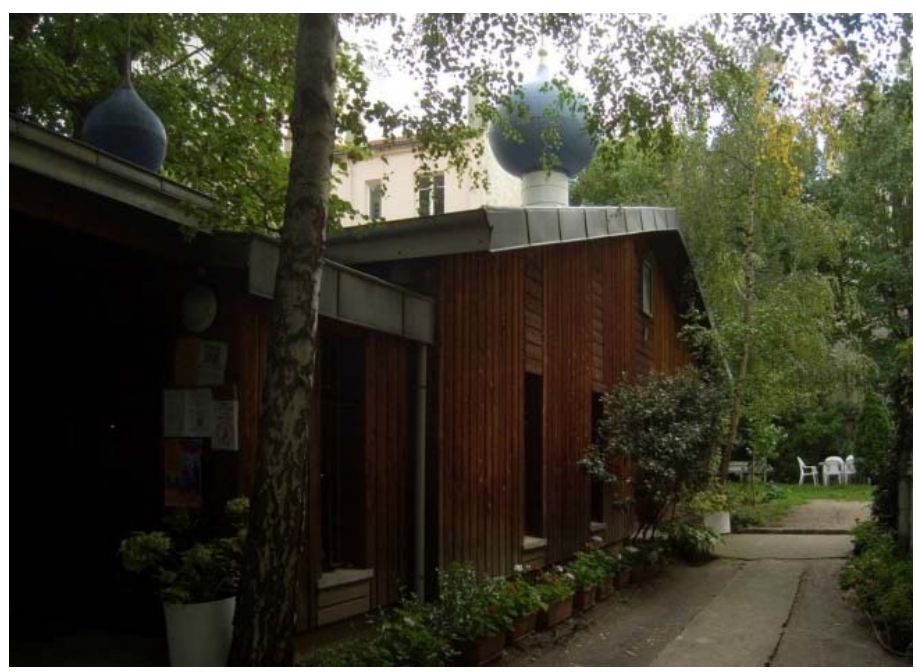

Figure 8. Russian Orthodox Christian Church in Paris - eco-architecture in church design

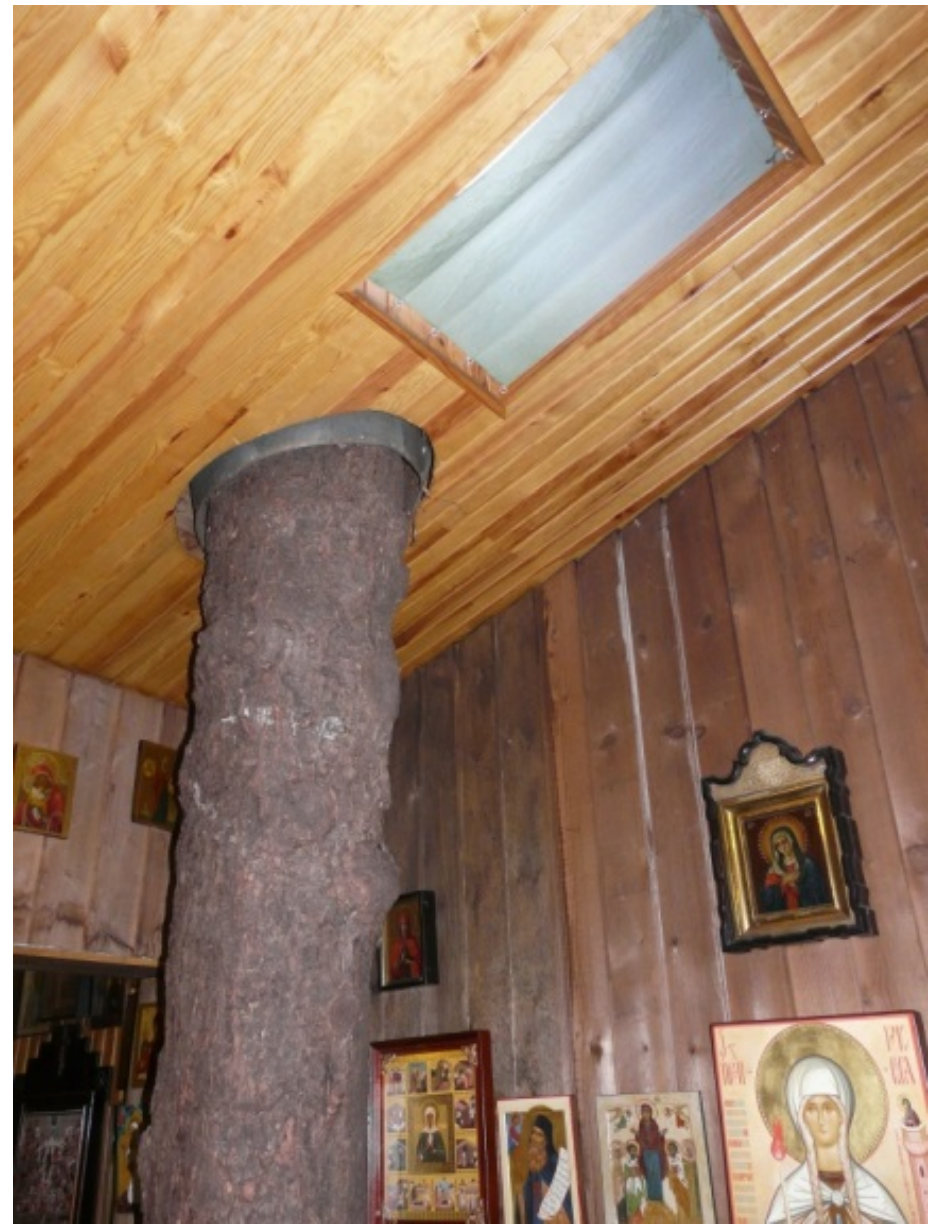

Figure 9. Tree trunk incorporated in the church building - eco-architecture in church design 


\section{Theoretical Considerations for Development of the Design Approach: Conceptual Design Elements and Limits of Experiment in Architecture}

The complexity of the Orthodox Christian architecture and the challenges the contemporary architect encounters in the process of its design require a specific methodology that would provide a design approach structure.

Whenever the theoretical explorations are involved in determining the image of a building, the main factor or the structuring theme determining the design is usually identified as an architect's concept or a parti. The competition for the construction of the Russian Religious and Cultural Center in Paris has illustrated that an architectural concept alone may not be sufficient for the creation of the architectural narrative for the contemporary Orthodox Christian church. Aside from embodying the synthesis of Russian sacred architecture and the contemporary architectural styles, the church building has to communicate a theological concept. The main idea that the church building has to communicate is an architectural metaphor of the "transfigured world". So, in this case, the architectural concept of the synthesis of architectural styles (both heritage and contemporary, ethnic and international) is not the main focus of the architectural narrative, but merely a prism through which the ultimate message of the Orthodox Christian Church building is refracted to become relevant to the current generation. Given the inherent complexity of the architectural narrative of the Orthodox Christian church and the diversity of the contemporary means of the architectural storytelling (stylistic and technical), it is necessary to establish the limits of the architectural experimentation in order to successfully implement the experiment in developing the new image for the contemporary church.

The best example to discuss the limits of such experimentation, as well as other conceptual design factors that have the profound effect on the design outcome, is the 
Reversible Destiny project by Madeleine Gins and Shusaku Arakawa. The project is an architectural experiment in pure form, which is designed in accordance with the specific framework: regardless of the kind of a building or a site it produces, it is dedicated to a sole purpose and relies on specific definitions of dwellers and their environment.

\section{Design Elements}

As illustrated by the precedent, the architects, who designed the Russian Orthodox Christian church in Paris, focused on the exterior appearance of the building and its coordination with the urban surroundings of Paris. However, these design aspects are not of primary importance. The difficulty of incorporating various design aspects in the Orthodox Christian church design in such a way that the structure would successfully function and communicate the coherent narrative can be resolved at the conceptual design stage with the establishment of a hierarchy between the design aspects. Due to the fact that in the Orthodox Christian church the interior space is more important than the exterior, and the building has to serve as a communication tool conveying the architectural metaphor of the "transfigured world", it is necessary to start with the definition of the intended user of the space and the outline of the user's needs in terms of supplying the building with the necessary functions and with the information layer integrated in its image. The following step of the design process would involve creating an environment which would allow to perform the necessary functions and to deliver the message to the users of the space in a way that it will be understood by them. All the other conceptual design aspects, such as the response to the urban and temporal context, the creation of a cultural dialogue, etc., would be addressed in accordance with the established framework, described above. The Reversible Destiny project by Madeleine Gins and Shusaku Arakawa illustrates how the specific definition of dwellers 
and their needs, as well as the creation of an environment that would be tailored to this definition have a strong influence on the image of the building.

Arakawa and Gins have come up with revolutionary architectural theory that challenges traditional understanding of dwelling and raises some ethical questions. Despite various differences between the types of dwellings the perception of the dwelling was common: it was seen as a temporary refuge for a human being before he or she will cross the boundary between life and death. Arakawa and Gins propose a new form of dwelling: a tool that would allow humankind to postpone and eventually even conquer death. The architects have written a number of theoretical works and have built a few projects to test their theory in reality. Their position towards architecture is expressed in following statements in their book "The Architectural Body":

“... architecture as we newly conceive it actively participates in life and death matters. Architecture, in anyone's definition of it, exists primarily at the service of the body. The question arises as to how to be most fully at the service of the body."

They perceive architecture as the greatest tool that can help human race to learn how "not to die"7.

"The architecture we speak of in this book is within our species' reach. It will be a way to undo, loosening to widen and re-cast, the concept of person. People will not be defeatists about a condition - the human condition - about which something can be done." (Gins and Arakawa, Architectural body, xi-xii)

Arakawa and Gins have created new terms and redefined the old ones with the aim of explaining their theory. Various neologisms that they have created to form a conceptual

\footnotetext{
${ }^{7}$ Indefinitely prolong life in a physical body.
} 
apparatus of their new philosophy do have a dictionary entry. New terms are created through various methods, such as: affixation (eg. "over-allness"), compounding (eg. "event-fabric"), placing a word into different category while maintaining the same morphology (eg. "to person", as in "organism that persons"), etc. (Lecercle and Kral, Architecture and Philosophy, 208-10). Their terminology defines their design process and outcome. The architects' definition of an inhabitant, as "organism that persons" (where "persons" is a mode of acting) delineates their architecture as an environment that strictly serves a biological entity. Therefore, the built forms they produce are dedicated entirely to stimulating the physical body that acts like a person. Their buildings and sites have common traits, because they represent various spatial configurations of the same environment with the same ultimate purpose: achieving immortality in bodily form. The outward appearance of their sites is not important to the architects: the sites are focusing on serving the ultimate purpose.

The projects illustrating the Reversible Destiny architecture ranging from a single family house to a park are the following:

- Bioscleave House or Lifespan Extending Villa (East Hampton, New York, 20002008) (Figures 10, 11)

- Reversible Destiny Lofts (Mitaka, Tokyo, Japan Completed October 2005) (Figures 12, 13)

- $\quad$ Site of Reversible Destiny - Yoro (Yoro, Gifu Prefecture, Japan, 1993-1995) (Figure 14)

Bioscleave House (Lifespan Extending Villa) is the first architectural project that the Reversible Destiny Foundation completed in the United States. The house has four rooms, a free-form living space and walls made of various materials, such as metal and 
translucent polycarbonate. There are no internal doors and the rooms have levels that create the impression that a person is in two places at once. The function of internal space redefines a conventional idea of what a room should be. By challenging the common understanding of how architecture should work, the inhabitant may be changing his or her ideas about how life should work. The Bioscleave House draws its name from the way a body holds, or cleaves, to these surroundings.

Reversible Destiny Lofts - Mitaka (In Memory of Helen Keller) is a nine-unit multiple dwelling created for elderly residents and was meant to help them prolong their lives by constantly adapting to their surroundings.

Site of Reversible Destiny - Yoro: the Site of Reversible Destiny - Yoro Park is an "experience park" conceived on the theme of encountering the unexpected. By guiding visitors through various unexpected experiences as they walk through its component areas, the site offers them opportunities to rethink their physical and spiritual orientation to the world.

Despite the unique appearance of Arakawa's and Gins' creations, "Reversible Destiny" dwellings consist of modules that stay relatively the same even if the geographical site of the project might change: they are either spread around the site or are stacked one on top of another to a specific height. Either configuration of "Reversible Destinies" designs is meant to serve the same purpose which aims to perpetually enforce the feeling of uneasiness and state of alertness resulting from it. The appearance of architectural designs that embody the "Reversible Destiny" concept can likely be traced to traditional Japanese architecture (the presence of architectural elements derived from the traditional methods of construction, such as tamped earth floor or doma) (Takeshi. The Japanese house: in space, memory, and language. 009) and the experiments of the 
20th century like metabolism (the modules that make up the "Reversible Destiny" dwellings can be seen as reinterpretation of Metabolist capsules) (Frampton. Modern architecture: a critical history. 282-4). The approach to architectural design of "Reversible Destiny" dwellings and sites may also originate in Japanese perception of space which is driven by constant awareness of the lack of space on the island and therefore results in special emphasis of spatial configurations of a building in order to get the most from the smallest area (Nitschke, From Shinto to Ando, 35). However, despite familiar features that relate their design to its cultural surroundings and architectural predecessors, the "Reversible Destiny" dwellings are drastically different in essence. Their designs epitomize the attempt to fight the inevitable, which results in the most radical version of the traditional architectural forms. While the architectural concept of the "Reversible Destiny" dwellings is creating the stimulating environment for the dweller to prolong life, their ultimate purpose or a meta-function, which governs the design, is achieving immortality in the physical world.

\section{The Limits of an Experiment in Architecture}

The technique for maintaining wellbeing and extending life that Arakawa and Gins have embedded into their designs presents a very different approach to elderly care, as opposed to common approaches in U.S. and in Japan - the countries, where the architects have originated from. Despite the fact that the "Reversible Destiny" dwellings, such as Bioscleave House or the "Reversible Destiny" Lofts in Mitaka, are complying to building codes and provide certain utilities that will allow their elderly residents to navigate through the space and to use the space safely while making the dwelling a place of adventure and healing (such as floor-to-ceiling poles of various colours located throughout the building, which act as supports and visual markers, or grab bars near the shower and toilet) (Wid and Rosenfeld. Unassisted living: ageless homes for later life, 
144-7), this type of dwelling might not reach its intention of healing its resident. The sensory stimulation created in such a dwelling might be detrimental to a person's health if the burden placed on one's organism will be incompatible with the damage already sustained by the organism. The more advanced the illness, the lower the probability of the treatment being effective. Also, it has been established that even life-sustaining treatments for the elderly might cause harm to a patient (Caring for the elderly in Japan and the US, 129-30), not to mention the conditions in which an elderly person will be put in a dwelling designed by Arakawa and Gins. The health and life sustaining technique inherent in the "Reversible Destiny" dwelling appears to be an extreme version of existing technique of elderly care which allows an elderly person to be active through physical and mental exercise, as well as through maintaining their presence and participation in a life of a multigenerational community. The "Reversible Destiny" Lofts in Mitaka, Japan, as well as other Reversible Destiny sites, consist entirely of kind of spaces that would be challenging to use even for able-bodied young people.

It is debatable whether the Reversible Destiny sites and dwellings can actually help the dweller to achieve immortality in a bodily form, since they contradict the contemporary understanding of elderly care based on the current research findings. It is possible to say that the limits of the experimentation in architecture are reached when the building resulting from such experiment cannot serve the intended purpose.

As illustrated by the Reversible Destiny project, the following conceptual design elements can determine the appearance and function of a building aside from an architectural concept: the outline of the meta-function, the specific definition of the dweller, and the establishment of the environment for an event to take place. These design elements may be integrated in the design process of the contemporary Orthodox Christian church to provide the structure for creating an architectural narrative, which 
can communicate the main idea of the building in terms that can be understood by the particular user of the space. 


\section{BIOSCLEAVE HOUSE - LIFESPAN EXTENDING VILLA}

WALL CONFIGURATIONS

(INTERSECTING AND SYMQMETRICALLY PAIRED)

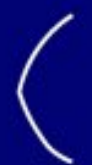

NOT SIMPLY ABUTTING

AT THEIR ENDPOINTS

BUT INTERSECTING

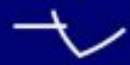

ONE. ANOTHER

AT VARIOUS ROINTS ALONC

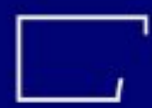

THEIR LENGTHS,

WALL-CONFIGURATIONS

HAVE THE SAME SEPARATE

AND DISTINCT CHARACTER

IN THE BUILT WORK

THAT THEY HAVE IN PLAN.

COMPLEIE SET OF SHAPE-DEFINING ELEMENTS

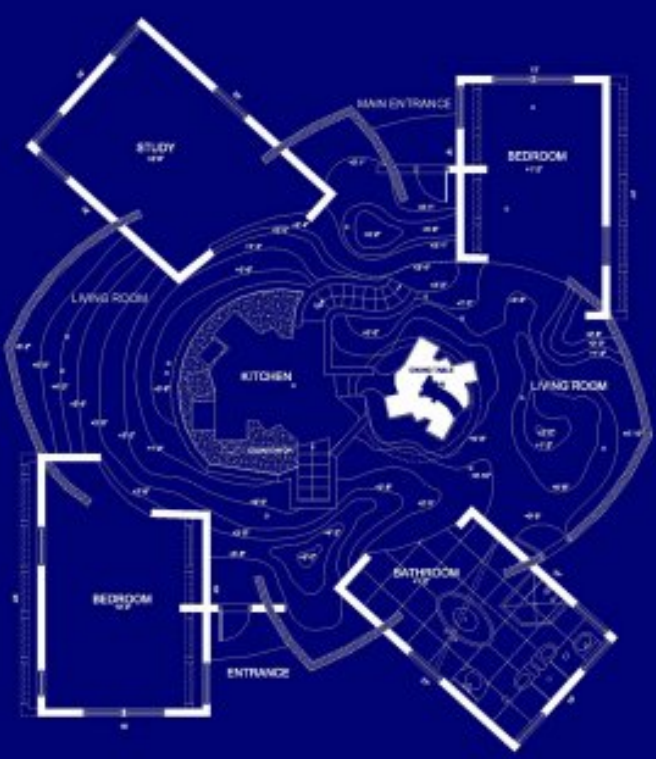

Figure 10. Bioscleave House (Lifespan Extending Villa). East Hampton, New York, 2000-2008
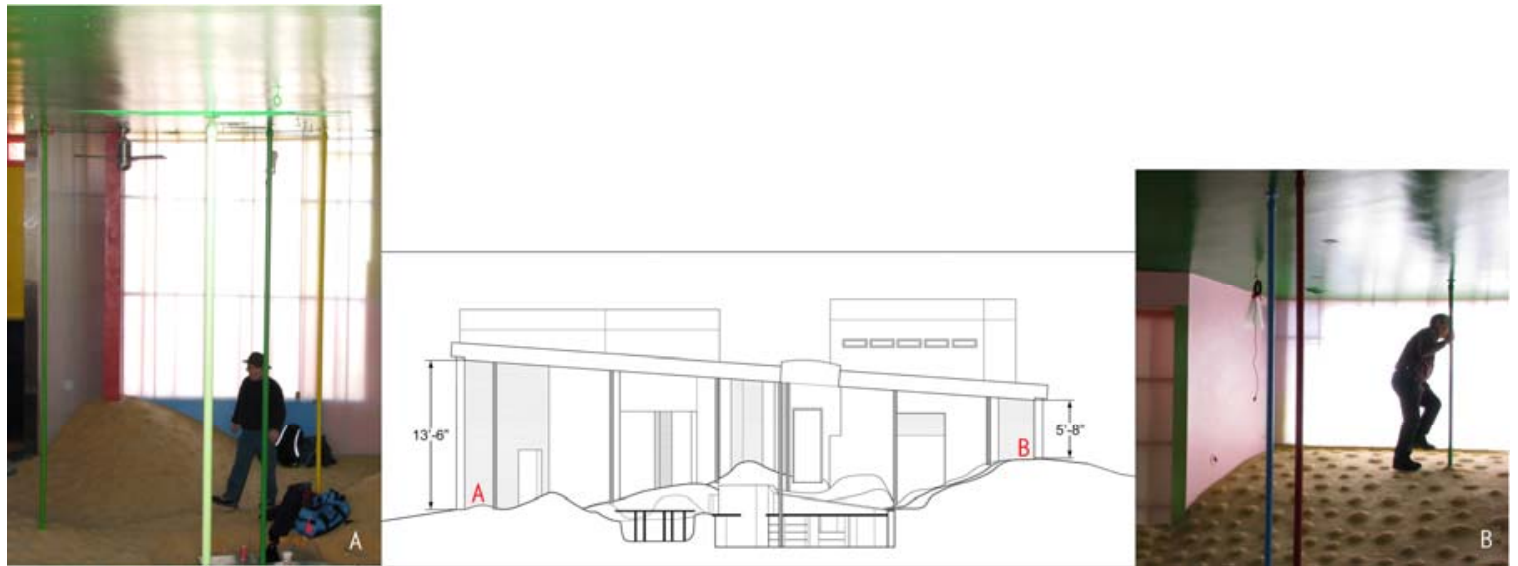

Figure 11. Bioscleave House 


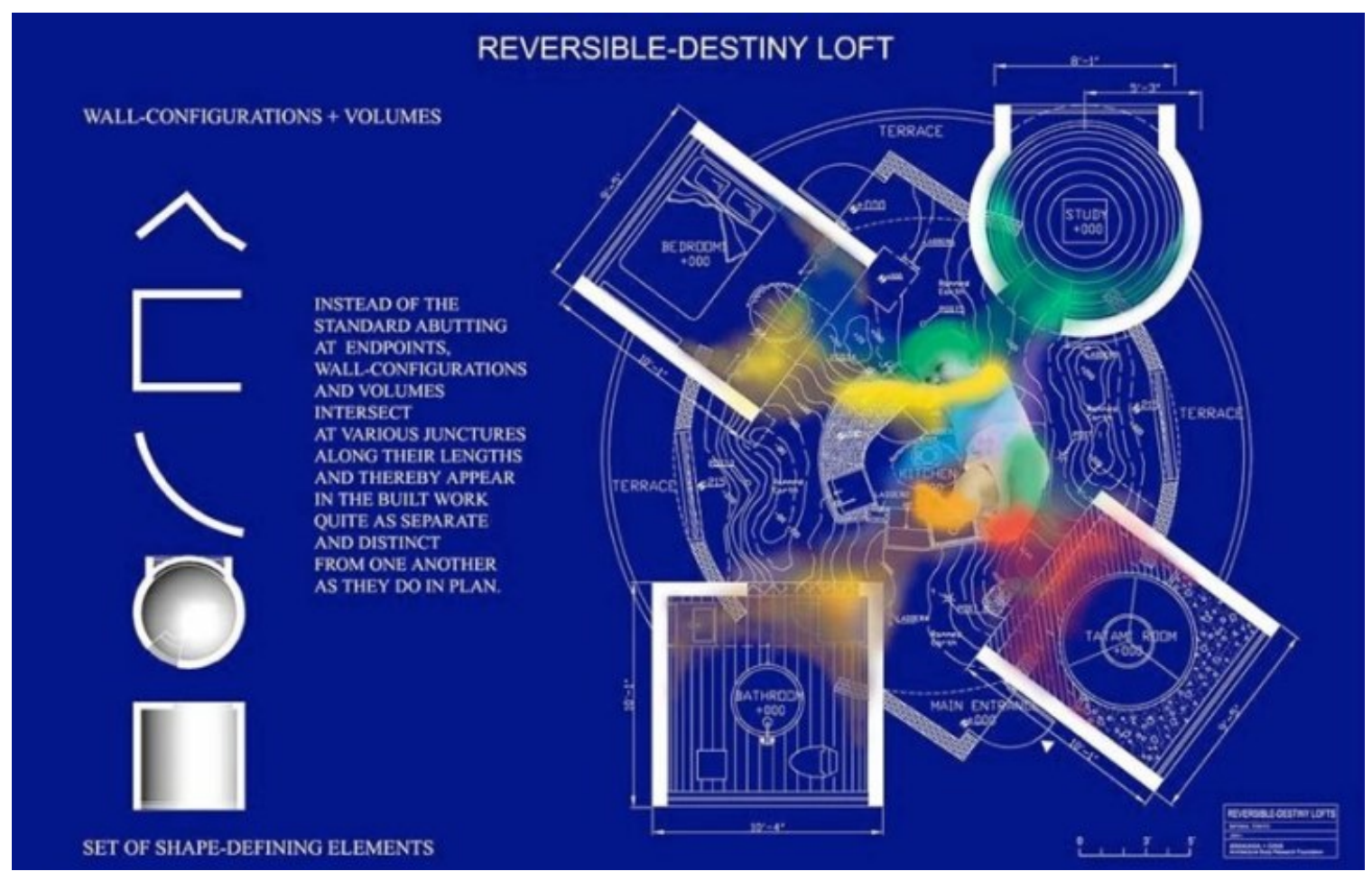

Figure 12. Reversible Destiny Lofts. Mitaka, Tokyo, Japan Completed October 2005

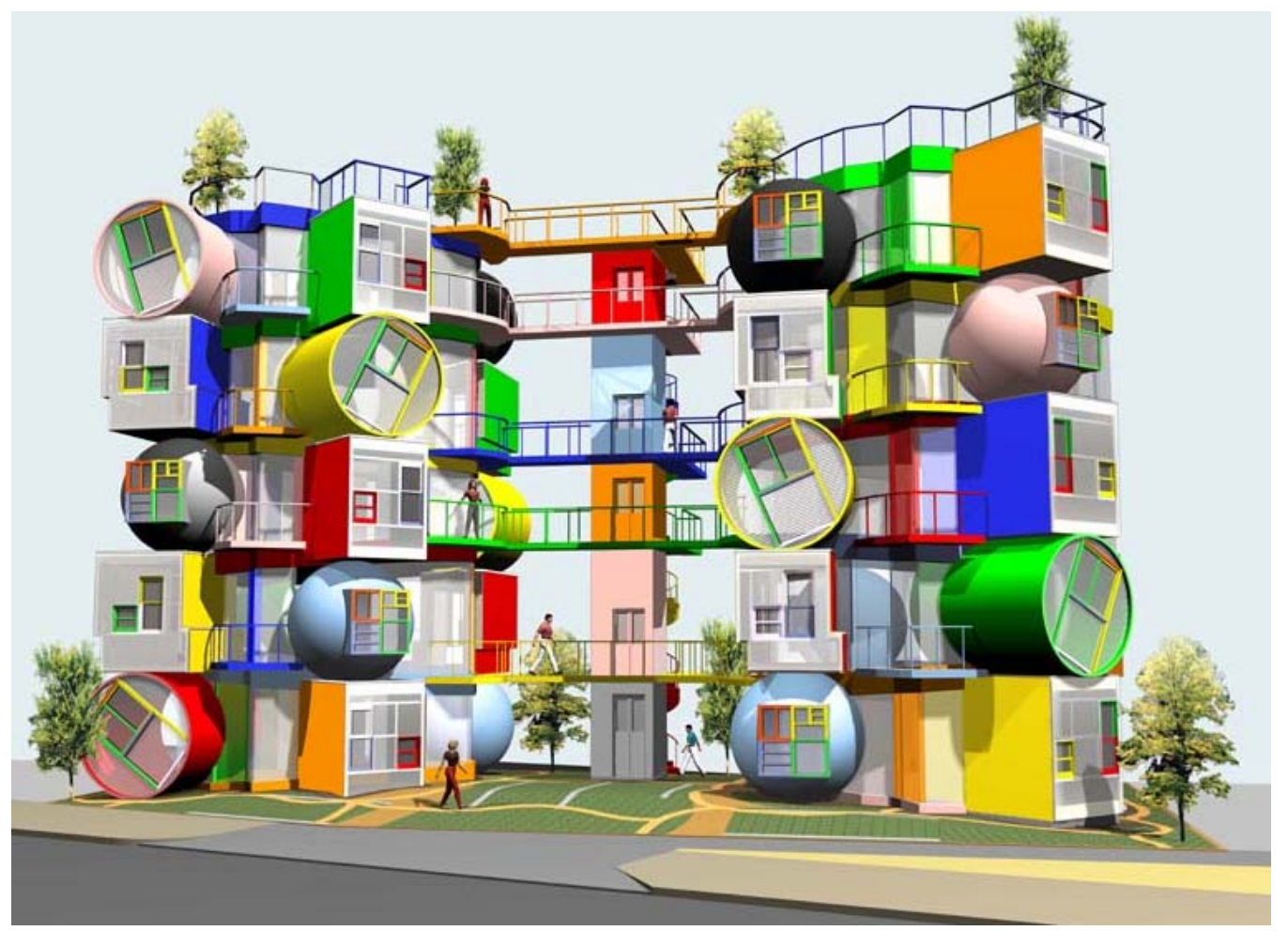

Figure 13. Reversible Destiny Lofts 


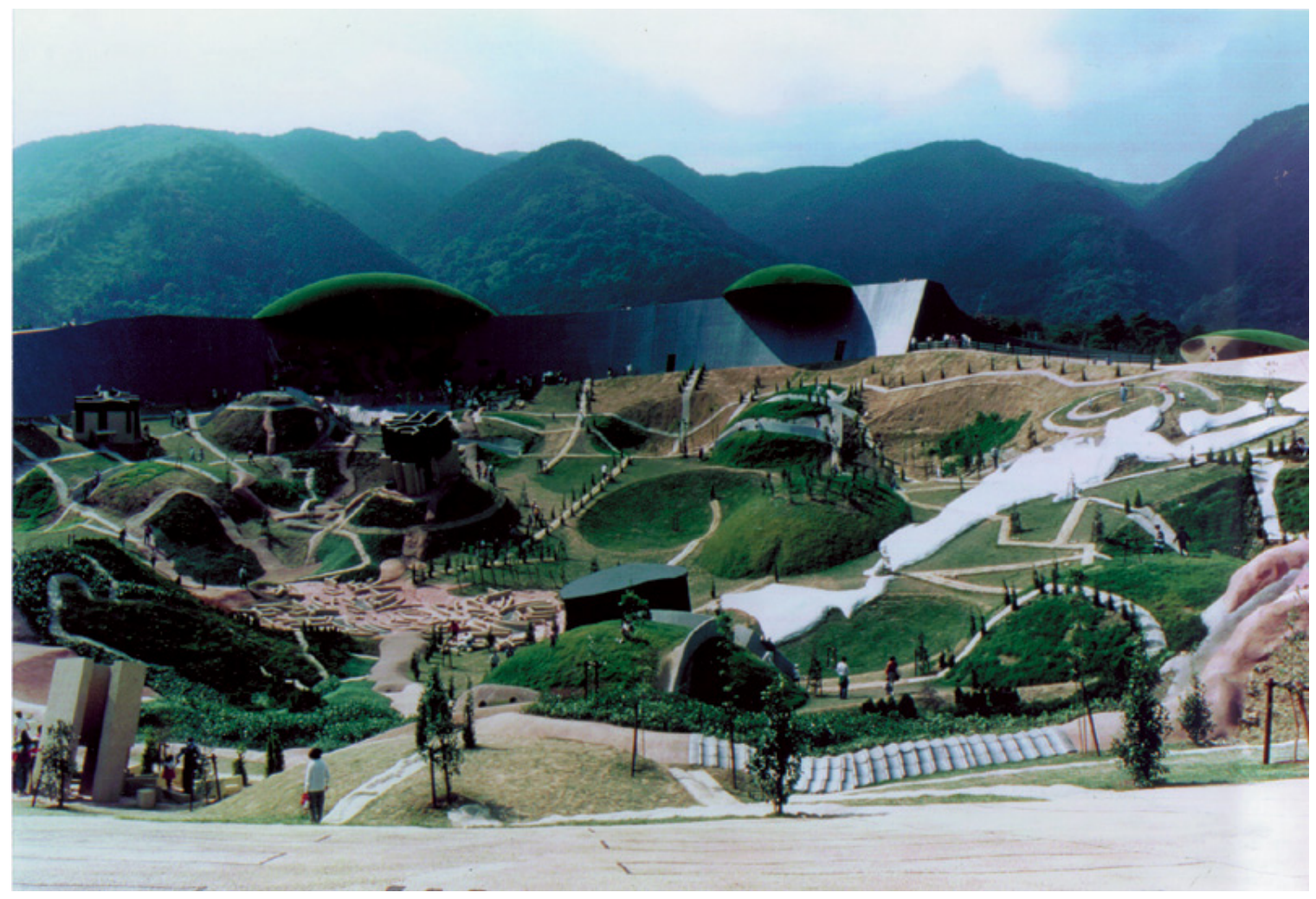

Figure 14. Site of Reversible Destiny. Yoro, Gifu Prefecture, Japan, 1993-1995 


\section{The Approach to the Conceptual Design of the Contemporary Orthodox Christian Church and its Applications}

The current urban, architectural and social conditions require an approach to the design of a contemporary Orthodox Christian church, which is different from the ones used in the past centuries. The new approach should respond to the diverse communities of the modern cities; address the challenges posed by chaotic and non-hierarchical urban surroundings; and take advantage of opportunities created by new materials and construction techniques, as well as contemporary architectural styles or "languages". In addition, the approach has to provide an architectural narrative that the contemporary user of space can perceive and relate to, since in the Orthodox Christian church the narrative is a function.

\section{The Conceptual Design Approach Outline}

Based on the previously discussed contemporary church design requirements and other conceptual design considerations, such as the church design principles discussed in this thesis, the steps of the approach were derived as follows:

Step 1: outlining the meta-function or the essential purpose of the building

Step 2: defining the intended users of the space, as well as the spatial and temporal context of the prospective building

Step 3: creating an environment (a microcosm), (self-sufficient universe, designed around the most important functions and areas, i.e. designed "inside-out")

Step 4: creating the architectural narrative: the message the structure conveys through its function and appearance.

As illustrated in the description of the Reversible Destiny projects, the meta-function is the essential purpose of the building. The meta-function allows defining the unifying 
theme expressed by the building, where every provision and design solution is dedicated to serving the meta-function aside from accommodating various other needs. The metafunction of the church in this case is not merely providing a place of worship for a given religious community, but to serve as a model of the universe (a microcosm) and an icon of the transfigured world (restored and renewed in the Kingdom of God).

A specific definition of a user of the space and the context of the building (spatial, temporal, and social) allows addressing the user's needs beyond those outlined by conventional design guidelines and building codes. For instance, the notion of an inclusion can be attributed not just to situations where the users of the space require accessibility provisions, but also to the situations where people of various cultures can become familiar with the activities that the cultural building is dedicated to. As for the accessibility provisions, they can also become a method of communication in the framework of the design (a part of the narrative).

In case of the church design, the users of the space can be defined in reference to architecture and in reference to theology. The users of the space are the parishioners as well as occasional visitors who come to take part in certain events or simply to explore one of the city's cultural artefacts. Aside from the general group of users of the church space (parishioners and visitors), there are various subgroups that require specific design solutions (people of other cultures, mothers with small children, people that require accessibility provisions, etc.).

The church design should strive to accommodate everyone in the community as much as possible, since the contemporary urban centers feature very diverse population and persons with various needs. Designing the space for various cultures includes finding 
the common ground in the architectural design expression in order to create a narrative that all the members of the diverse community can relate to.

The theological concept expressed in the given design is based on conceptual relation of a person to the church building. A human being is described as a macrocosm, while one of the symbolic meanings of the church building is a model of the universe: a microcosm. Thus, the given design represents the macrocosm contained within a microcosm, conveying the relation between a human being and the created world. The architectural concept of the reversed relationship between macrocosm and microcosm in the building is derived from the comment on the ideas of St Maximos the Confessor provided by the $20^{\text {th }}$ century theologian Fr. Dumitru Staniloae:

"Some of the Fathers of the Church have said that man is a microcosm, a world which sums up in itself the larger world. Saint Maximos the Confessor remarked that the more correct way would be to consider man as a macrocosm, because he is called to comprehend the whole world within himself as one capable of comprehending it without losing himself, for he is distinct from the world. Therefore, man effects a unity greater than the world exterior to himself, whereas, on the contrary, the world, as cosmos, as nature, cannot contain man fully within itself without losing him, that is, without losing in this way the most important reality, the part which, more than all others, gives reality its meaning." (Staniloae 1994)

The creation of an environment (a microcosm) allows placing emphasis on the design of the most important spaces and establishing a hierarchy in design, where the outward appearance is secondary to the function. In case of the Orthodox Christian church design the interior of the church where the event takes place (where the liturgy is served) is more important than the signifiers that the exterior of the church contains, so that the church is designed "inside out".

The environment of the church focuses on the performance of the liturgy and all the design aspects should be subordinate to this function, for example: the space where liturgy is performed should be easy to locate, easy to access and properly set-up for use. Any other design decision should be implemented in a way that will not interfere with the 
above-described set-up. The environment should be consistent with the architectural design principles used for creating the space of the Orthodox Christian church, i.e.: beauty, hierarchy, harmony, constancy, etc.

The architectural narrative allows the building to refer beyond itself and to provide the additional story lines and methods of expression to the message the building already communicates. The architectural narrative in the contemporary sacred architecture should address the message that is relevant to the given community in the given times, in other words, can be understood by contemporaries.

The approach creates a framework for designing a harmonious, unified by a theme (meta-function), space that uses the response to the necessities and the special circumstances as the means to provide an additional information layer (a narrative) complementary to the function, while providing an environment for an event to occur. Due to the fact that the approach is based on the fundamental architectural design principles consistent with the Vitruvian triad. It creates a built environment which possesses the constant qualities (harmony, beauty, hierarchy, etc.). These qualities render the image of the building stable and recognizable in essence despite the variability of the designs' appearance and typology.

Buildings that accommodate the transition bear similarity with the Orthodox Christian churches, the narrative of which is based on the notion that the entire life of a human being in the created world is transitory. Such building designs can serve as "anchors" that establish a reference point for persons in transition, in the same way as the church buildings are designed to remain recognizable to any users of the space regardless of the time and place the buildings have originated from. 
The following thesis project will illustrate how the above-described conceptual design approach can be implemented to create the image for the contemporary Orthodox Christian church.

Thesis Project Description

Project title

Holy Wisdom (Hagia Sophia) church complex

\section{Location}

Downtown area in the city of Ottawa, Ontario, Canada (in the vicinity of the Bayview station, near the intersection of the major East-West and North-South public transport routes) (Figure 20)

\section{Functional typology}

- Parish church

In this case the church complex incorporates various auxiliary spaces that may be needed for the parish church to function in the contemporary urban environment.

The church building will be used in a similar manner to the churches in large European cities: the church is not attributed to a particular parish but rather accommodates various citizens who can attend at any given time.

\section{Occupancy}

100 seating or 200 standing (or 300 standing if the partitions are removed between the church space and the lobby) 


\section{Reference project}

The refectory church located in the Kiev Pechersk Lavra (Monastery of the Caves) complex in Kiev, Ukraine (Figure 15).

The spatial arrangement of the functional areas and the geometric articulation of the building in the given design is similar to the refectory church.

\section{Architectural styles}

- Constructivism

- Deconstructivism

- Biomorphism

These architectural styles were not traditionally used in Orthodox Christian church design. They might appear to be incompatible with the architectural design principles that define the appearance of the church. These styles have been selected in order to illustrate that any architectural style can be suitable for the church design if it is subordinate to the main idea expressed by the building.

\section{Objective}

The design objective is similar to the requirements for the precedent: the Russian Cultural and Spiritual Center in Paris (2011), which had to embody the synthesis between traditional Russian Orthodox Christian architecture and the contemporary architecture. Just like the Center in Paris, the Holy Wisdom church also functions as a cultural object in a diverse ethnic setting and is located in a country that has dissimilar architectural traditions. However, the thesis project is not limited to the Russian traditions within the Orthodox Christian architecture heritage. 
The additional objective is to design a building, which is clear in its intent and which can communicate the importance of its areas at a glance though their function, their arrangement in space, as well as the use of materials and colour.

\section{Architectural concept}

An architectural representation of a theological concept of human being as a macrocosm (Staniloae 1994). A macrocosm that is contained within a microcosm (an entity that exceeds the boundaries of the created world), since the one of the meanings attributed to the church building is a model of the universe (a microcosm).

\section{The Narrative and its Translation}

"Personal narratives build on the cognitive mechanisms that arise from existing places and spaces. Narrative has its roots in the world we inhabit, and occurs at the interface between our own experience and complex signs, like the little red pointers that smother other data on Google maps. It does not necessarily manifest as appearance; the fields of Flanders where so many First World War battles took place have an emotional significance as a sign of loss but today look much like any other. We are walking encyclopedias of architecture not because we've shaped it, but because we experience it." (Coates 2012, 014)

As it was illustrated in the precedent, a cultural artefact in a different setting requires particular design decisions to make it appear belonging to the new context. A traditional Russian Orthodox Christian church building with golden "onion" domes located in Moscow would be perceived by a city dweller differently than if it was located in Paris. To an average Muscovite it would be a recognizable architectural symbol that is present in many parts of the city as well as in other cities and villages of the country. It would be a symbol that represents the beliefs of the prevalent religious denomination of a nation, the place where generations of ancestors came to participate in services and share their lives, a monument for a particular historical event, etc. The golden domes glowing in the sunlight may appear similar to the candle flames lit by the regular churchgoers and occasional visitors. A certain knowledge of the church architecture would also bring to 
mind of the Muscovite the wish of the believers to use the best available materials, such as gold, and the most advanced construction methods, because such buildings were dedicated to God.

However, such memories, experiences and metaphors would most likely be absent from the personal narratives of an average Parisian. To a Parisian the same church would most likely appear to be a foreign object in a homogeneous urban fabric created by Baron Haussmann. It would bring to mind another historical allusions and metaphors, since the city dweller in Paris would not share the collective memory, religious, and cultural experience as his or her contemporary in Moscow.

Consequently the architectural narrative of a cultural object, which is "foreign" to the given environment, has to be "translated" in order for the local community to understand it. Even though such cultural object possesses its own narrative, it can still be integrated with the narratives of its new geographical location and the cultures, which become the "recipients" of this cultural object. There are many ways to design a cultural object to be "readable" by a local community at the same time enhancing its performance. For instance, taking inspiration from local construction techniques and building typologies can adapt the new buildings to a given climate, in addition to making their appearance recognizable to the locals.

Integrating foreign and local narratives is meant to produce an architectural artefact that possesses "novelty tempered with familiarity" (Smith 1998, 15) in order to appear recognizable and at the same time to challenge the passer-by to discover it.

The multiple narratives told simultaneously in one building rely on multiple meanings in expressions of the same fragments of the narrative. The texture of the interior cladding, 
the light passing through the windows inside and outside, the geometric shapes of the structure can function as different synecdoche in various circumstances.

\section{Description of the Spaces in the Church Complex}

Main level consists of the "family space" (lobby), which is a public area, and the actual church space. The "family space" is reminiscent of geometric articulation and of the space qualities inside a longhouse, where multiple families traditionally lived together in some of the First Nations of Canada (Kroeker 2013). The church space consists of the narthex, the nave and the altar, with the choir space is located above the narthex and the adjacent portion of the nave.

Lower level consists of various auxiliary spaces under the volume of the "family space", the learning and work spaces under the volume of the nave (offices, classrooms, library, etc.), and the chapel under the altar space (Figures 21-27, 36, 37).

\section{Architectural Narrative}

The arrangement of the functional spaces in plan on the lower level emphasizes the hierarchy of functional spaces on the upper level, where the chapel is located under the altar, the learning and work spaces are located under the nave and various supporting functions are located under the area that corresponds to the public realm: the "family space" or the space that corresponds to location of the refectory in the functional spatial arrangement of the reference project: the Refectory church in Kiev Pechersk Lavra.

In terms of fire safety, the church of such size and interior design requires two more fire exits from the nave (Allen and lano 2011, 306). The church space has to be unsprinklered, since the interior features frescoes, which can be ruined by water. The fire exits and the paths used for fire escape can be incorporated in the architectural narrative and serve as a way of communicating the concept. Fire escape paths create 
"halos" that are intersecting and encircling the church building inside and outside. The paths are integrated with the area for procession, which is located outside the church and is used during certain holidays. This way the fire escape paths act as means of architectural expression (Figures 18, 19, 28).

In order to accommodate various types of users of the space, such as visitors that do not participate in the service, mothers with small children, those who require various accessibility provisions, the following design solutions have been provided:

Aside from providing ramps outside and inside the complex to allow the wheelchair access everywhere on the site, the ramps and the paths connecting them have been integrated in the symbolic circulation scheme. The paths coincide with the "halos" encompassing the outside of the altar area, the nave, and partially the lower level of the complex. The circles radiating from the very center of the church, where the baptistery is located, and from the altar area, are expressing though architectural means the theological concept that a human being exceeds the boundaries of the created world (Staniloae 1994).

The narthex area is altered to function differently from the narthex areas of traditional spatial articulations of the church. It is expanded to accommodate more people, the opening between the narthex and the nave is widened, and the connection between the level of the preceding area ("family space" or refectory) is layered to emphasize the transition to another realm: from public area to the actual church space. The narthex is split into the three functional areas: area for mothers with small children on one side, the area for visitors on the other side, and the actual transition space in the middle. The strategic placement of the choir area above the narthex and the adjacent portion of the nave creates the sound buffer for the transitional area and enhances the sound 
transmission for the nave area. The layering of the entry to the narthex area is achieved through the strategic placement of the ramps in the center and the staircases on each side of the ramps. All visitors entering the church space, which they could see from the "family space", will change direction as they go up to the upper level of the narthex. The change of direction on their paths emphasizes the entrance to another realm.

As opposed to the traditional arrangement of colours in the system of fresco paintings from darkness on the lower levels to light on the upper, the frescoes in the church gradually reveal themselves as the gaze goes up from the monochrome wooden area of the lower level of the church ("Earth" realm) to the progressively brighter and contrasted colours of the frescoes in the upper levels (the space under the dome - "Heaven" realm) (Figures 30, 31). The lower level of the church interior, which corresponds to the "Earth" realm in the spatial symbolism of the church and where the parishioners stay during the service, will feature carved wooden monochrome icons for the visually impaired. By making the entire lower area in the church monochrome, with the exception of the iconostasis, every person entering the nave area is included in the set up created to accommodate the visually impaired, who require tactile representation of the images (icons) (Figure 33). This reverse inclusion is designed to emphasize the theological concept of the unity of humankind and to dissolve the separation that may occur when the accessibility provisions are not fully part of public realm and architectural expression. The creation of the monochrome interior with focus on colourful iconostasis is also another method of making the building "self -explanatory", so that the most important elements of the space are seen at a glance, which is important for the current generation that lives in the environment characterized by information overload.

The theological concept of a human being exceeding the boundaries of the world is also represented by in the spatial design by location of the baptistery in the center of the nave 
and the shape of the belfry located outside of the nave. The location of baptistery and the circles radiating from it in plan, as well as the surface of belfry that is offset from the volume of the nave, symbolically represent the superior significance of a human being in reference to the world, since they represent exceeding the boundary of the building (the main volume).

The material composition of the church also conveys the cultural narrative in form of the hierarchy in construction. The structure and the space qualities of the main volumes are reminiscent of the architecture of the First Nations and the design of Hagia Sophia in Constantinople at the same time. The overlay of frescoes and the stained glass are reminiscent of the sacred architecture brought by cultures that came to Canada afterwards. The resulting effect from the structure and overlays inside and outside creates a metaphor of beautiful natural phenomena of Aurora Borealis and the rainbow, thus applying the principle of beauty to the church design in an unconventional way (Figure 35).

\section{The Archetypes as Part of the Narrative}

The main volumetric forms of the church geometry also can inform a user of the space of the nature of the function assigned to such space: The Vault (reminiscent of longhouse) - represents an archetypal architectural form that embodies directional movement (ThiisEvensen 1987) and can be perceived as a space that leads to the dome. The Dome (reminiscent of igloo) is perceived by a spectator as "static" form (Thiis-Evensen 1987) and therefore reads as a final point of the journey (also due to the fact that its significance in the volumetric composition of the church is emphasized by its size in comparison to the vaulted volume of the "family space". 
The presence of water can be brought forward and intertwined in the architectural storyline by placing the stationary baptistery (which can be covered by wooden panels when it is not used) in the center of the nave right under the main dome (the most important space in in terms of placement of the pictorial narrative). Such location of the baptistery would bring the reflective effect of water as a means of expression in the narrative of the believers' journey to deification. The new life of the catechumen would start at the very center of the church from where the concentric circles are radiating and exceeding the limits of the building walls emphasizing the fact that a human being is larger than the created world. The first step in the new life is the decent in the baptistery: the steps leading to the altar doors echo the size of the steps descending into the baptistery to establish the sequential connection of the steps of symbolic death and the path to deification (the entrance to the altar through the ascension to the steps.) Due to the strategic location of the baptistery, the reflection of the main fresco of Christ the Pantokrator is reflected in the water where the believer would start his or her journey (Figure 31).

The resulting building is clear in its intent in terms of function. Such clarity is necessary to communicate an idea to modern people, who do not share the same cultural background and do not possess the same knowledge about the built environment. The building reveals the sacred spaces, which are emphasized by the use of special materials and by their separation in space from the rest of the paths and public spaces.

\section{Architectural Styles Incorporated in the Narrative}

In order to illustrate the idea that any materials and architectural styles can be used in the church design if they are subordinate to the main idea, the design incorporates the elements of biomorphism, constructivism and deconstructivism, since these architectural 
style appear to be among the ones least compatible with the principles of the Orthodox Christian church design.

Constructivism is represented by the addition of volumes (imperfect circles around the Nave) (Figures 18, 19) and adjoining of the "family space" (the refectory volume).

Deconstructivism is represented by peeling away of the belfry; the fire escape paths intersecting the building volumes; the concentric circles radiating from the baptistery surpassing the boundaries of the church walls and spilling over the surrounding landscape (emphasizing the idea of a human being perceived as an entity, which is larger than the world: a macrocosm contained within a microcosm).

Biomorphism is represented by the random arrangement of the windows that appears orderly on the inside of the building because it is symmetrically balanced along the axes of the church space and pulled together by the iconographic images that overlay the walls (both solid and transparent parts of the walls.) The creation of "Aurora Borealis" and "rainbow" effects also bear reference to the natural world. (Figure 29)

The combination of the above-described building elements illustrates how the use of any architectural styles can potentially be used as a way of conveying the message. In addition, the design emphasis on the most important spaces of the building allows to use the advantages provided by the given architectural style without interfering with the function of the building.

\section{Verbal Narrative as Part of the Design Process}

A verbal narrative can reveal what common traits the narrative fragments from the various storylines may possess. When describing the experience in the space of the traditional aboriginal buildings, such as igloo (Figure 16) and longhouse (Figure 17), and the sacred architecture of the French and British settlers, one can derive the similarities 
in the designs expressed through the geometrical shapes of the buildings, the qualities of light, etc.:

- translucent glow of thick igloo walls and colourful glow of the translucent panes of glass in Catholic and Anglican churches, that cast the shafts of coloured light on wooden floors as sunlight passes through the windows

- warmth and texture of the wood in the interior of the longhouse, designed to accommodate a few families at once.

The above-described qualities of light and material texture can be recreated within the church building in order for it to possess the qualities of space that were characteristic of all of its architectural predecessors.

The toponymical aspect of the narrative can also play a role in locating the building in public mindscape. The title of the thesis project: the Holy Wisdom refers to a quality that is highly valued in all cultures and therefore such choice for a name would create an opportunity for people of other cultures to relate to this object in their city. The name "Holy Wisdom" (and, in a certain way, its appearance) also embodies the idea of succession and connection between the believers through time and space: it brings to memory the Hagia Sophia (Holy Wisdom) in Constantinople and the Holy Sophia cathedral in modern Kiev, Ukraine, which was brought into existence when Kiev was a capital of Kiev Rus' and inherited the faith from Byzantium.

\section{Narrative on the Urban Scale}

The "narrative in space as opposed to literature or cinema has a firm basis in the way each of us learns to navigate and map the world around us" (Coates 2012, 014).

As a city dweller or a visitor explores the urban environment, certain cultural buildings, which could serve as the points of interest for both a city dweller and a tourist, may 
remain as voids in the person's mindscape because the access to such buildings appears to be restricted. The church with a small narthex, which was traditionally designed to be a small transitional space, does not appear welcoming to someone who wants to see the interior of the nave and the activities inside, but does not want to participate or fears that entering the nave would interfere a religious service in any way. On the contrary, designing the "extraverted" main entrance, the large narthex and its transition to the nave in such a way that would designate the functional and cognitive separation of spaces, while allowing to see the service without entering the nave, would allow the observation without interference and would encourage familiarization with another culture and traditions.

This would allow the members of society who do not observe the particular religious tradition to become acquainted with the purpose and functions of a given place of worship or any other type of cultural building, thus filling in the void as they map the city in their minds.

Extending the narrative the wooden structure of the church space is clad with the removable ceramic panels on the inside in order to use the ceramic surface for fresco painting in such a way that the creation of the fresco and its maintenance are much easier than they otherwise would be if the church ceiling consisted of brick vaults painted on site. Since the fresco layout has to be developed simultaneously with church building design, the removable panels allow easier coordination between the trades, starting the fresco painting off-site, and easier maintenance if the frescoes become damaged. The removable ceramic panels would also be easier to handle by the artists who are not very familiar with the ancient art of developing a fresco layout and painting it on a complex ceiling topography, such as a combination of multiple vaults. 
On the exterior the church domes are clad with white porcelain panels that have a layer small glass beads baked on their exterior surface. The resulting uneven texture on the panels does not produce sun reflection as an ordinary porcelain surface would. Instead the transparent layer of baked glass beads captures the rays of sun and refracts producing the static rainbow effect, similar to the one occurring in the mist when the sun rays pass through it. Such "rainbow", however, would not form an arc, but it is rather scattered on the surfaces of the church domes at the points where the sun reflects from the dome, as seen by an observer at a given location in a given time. Without the sunlight the glimpses of rainbow would disappear leaving only the off-white colour on the domes representing "heaven" realm, and the varying tones of grey colour of the weathered exterior wooden cladding of the other spaces, as well as the "earth" realm of the nave.

The conditions set in the church building for the "Aurora Borealis" effect to be perceived in motion include strategic placement of long and narrow vertical windows of varying heights in the domes of the altar, nave and choir, as well as in the walls of the additional spaces, such as the area for mothers with small children, the "overflow" space of the narthex and the walls of the basements spaces, which emerge from the sloping grade at different points. Certain glass panels on the interior or the altar, nave and choir are stained in order to maintain the continuity of the pictorial presentations overlaid on the inside the sacred spaces and to emphasize the importance of the interior space composed of the three above-described volumes.

"Aurora Borealis" reinforces the "kinaesthetic" quality of path in Kevin Lynch's terms (Lynch 1960, 97), so the church becomes an object in the urban fabric, the presence of which is emphasized in a new way, as opposed to the traditional ways employed in the cities of the Christian civilizations, such as placing a church at a point of convergence of 
the significant streets and/or constructing the church to become the tallest building in the cityscape. The given design for the contemporary Orthodox Christian church illustrates the technique of emphasizing the sacred architecture, which cannot compete with the height of the skyscrapers in the cityscape and the brightness of LED screens covering the walls of the downtown shopping malls.

The naturally occurring "Aurora Borealis" phenomenon, which reveals itself in motion as the cars pass by the church at a high speed, is noticeable but not obtrusive at the same time. The brightness of the "Aurora Borealis" does not exceed the brightness of any other lit window in an office building block or in a residential area, because it appears when the light inside the church passes through the coloured and transparent glass blocks. The convex and concave surfaces of the exterior walls, perforated by the strategically placed long and narrow windows appear to move past each other as a car approaches the church following the curved path of the road. Even though the building remains a fixed point in space, to a person in the car the "rotating" walls, seen at an angle from ground level, and the changes in the appearance of the "moving" windows, lit from within, create the playful dance of light and colour reminiscent of Northern Lights, as if they were contained within the building. In such a way the building establishes its presence in the cityscape, while acknowledging the fast-paced quality of contemporary life in a city.

Another way of emphasizing the presence of the building in a landscape is the creation of a "rainbow" effect that is visible under certain conditions during the day. The natural occurrence of the "rainbow" and "Aurora Borealis" effects in the building is consistent with the principle of authenticity, and therefore is in line with the guidelines for the Orthodox Christian church design. Both rainbow and Northern Lights occur in nature under certain circumstances and cannot be enforced or scripted. By transferring the 
natural occurrence of these atmospheric phenomena in the built form the architect emphasizes the fact that the phenomenon of religious belief, that the church building is dedicated to, is seen as something that also cannot be scripted and only comes into existence under certain circumstances. This segment of the narrative is told to a contemporary city dweller in terms that are easier for understanding in the digital age, when the verbal and visual information is abundant and is reproduced in such great quantities that an average person is not likely to take time to "read" into the verbal narrative or the symbolic visual "language" of an icon in the same way his or her ancestors did.

"Aurora Borealis" effect at night and the glimpses of "rainbow" seen on a sunny day are a way of assisting the city dwellers in starting their journey of discovery of the urban artifact, which they may otherwise dismiss as "foreign" and would avoid altogether if the architect would choose to recreate traditional historical image for the design of the church. The building would remain a void in their mindscape if they did not perceive its traditional architectural form as part of their heritage or a representation of place of their worship. The unexpected occurrence of the visual effect, which is reminiscent of the beautiful atmospheric phenomena, is a way of offsetting the city dwellers' expectations of how they might understand and classify this building in their minds. It is also a way of representing the idea that the believers perceive the church building as more than a structure that merely accommodates certain functions including the theological dimension of the architectural narrative. 


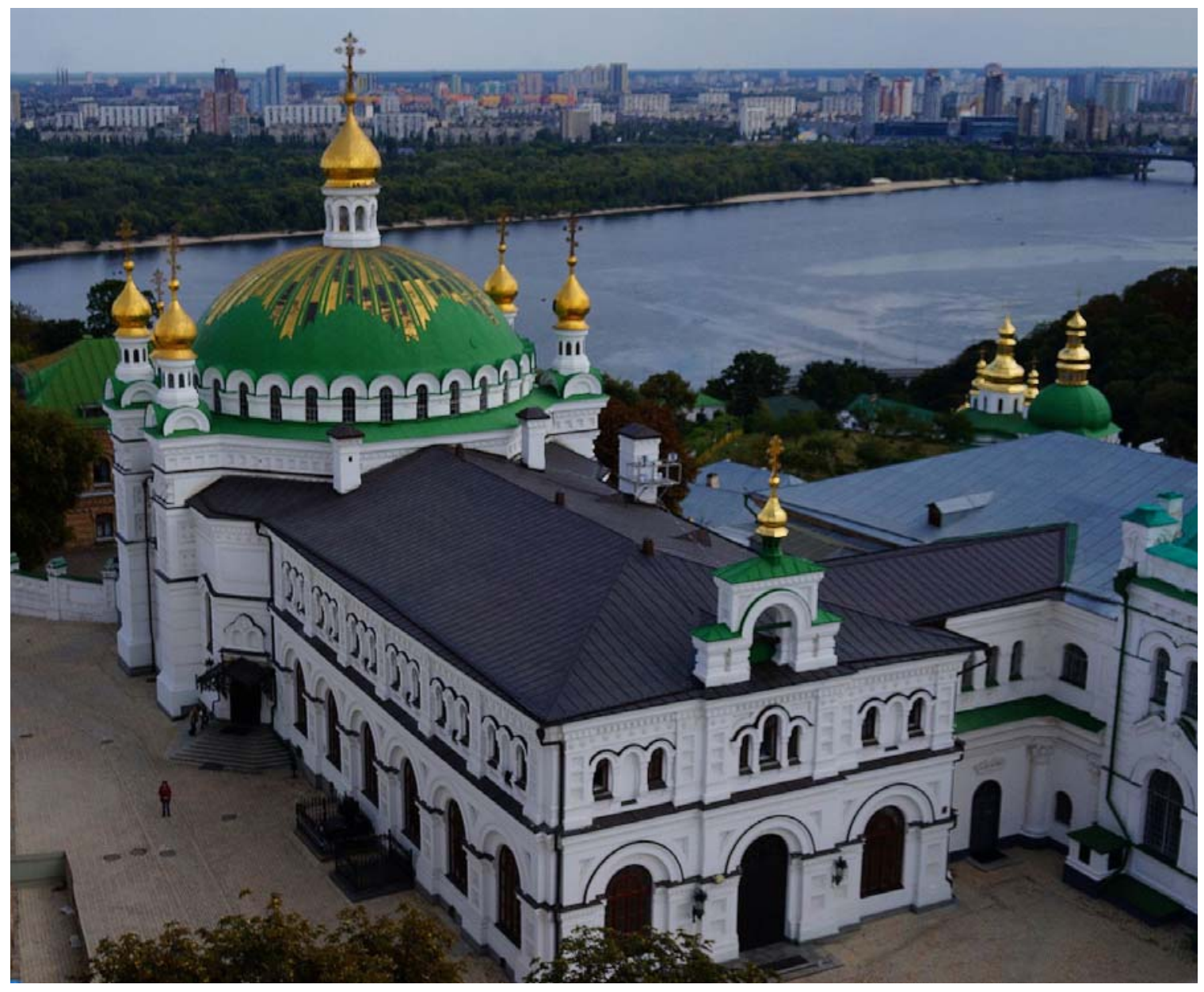

Figure 15. Reference project - Refectory Church in the Monastery of the Caves (Kiev Pechersk Lavra) in Kiev, Ukraine 


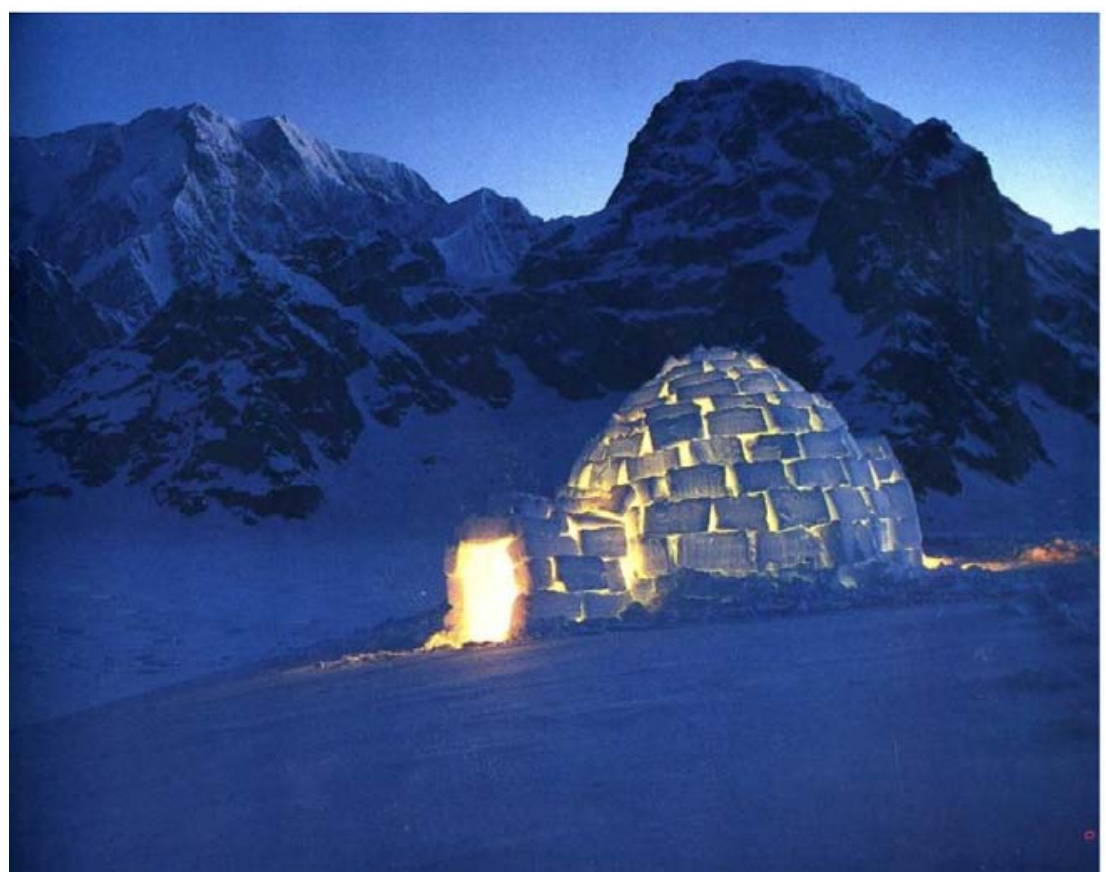

Figure 16. Architectural inspiration 1 - Igloo

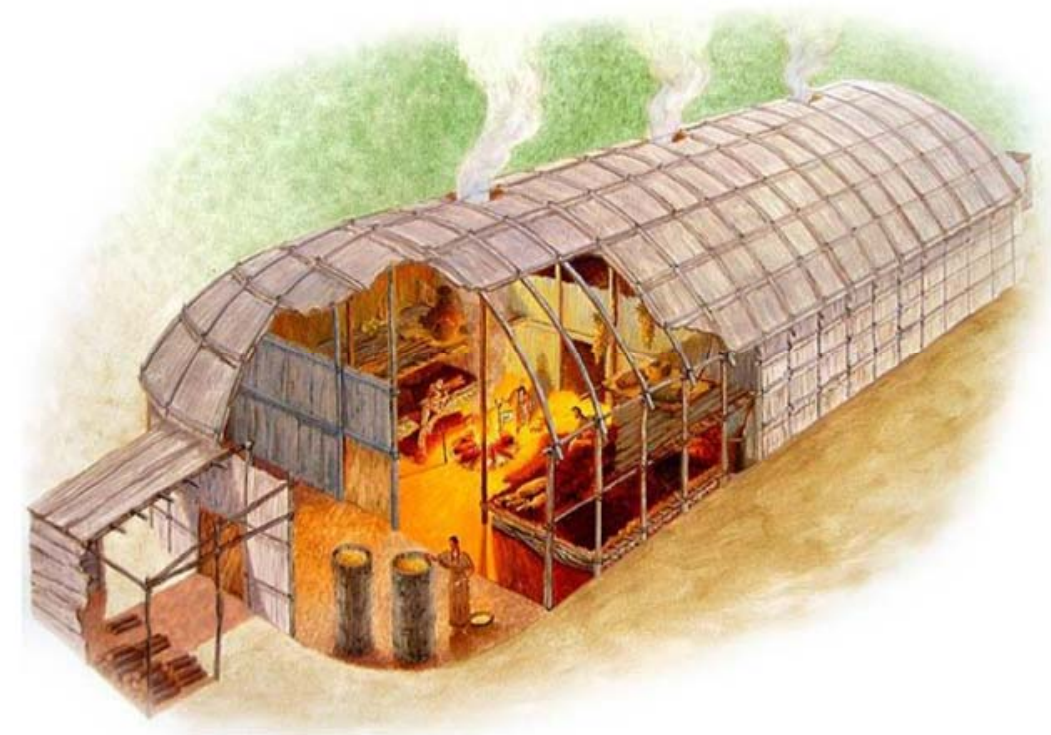

Figure 17. Architectural Inspiration 2 - Longhouse 


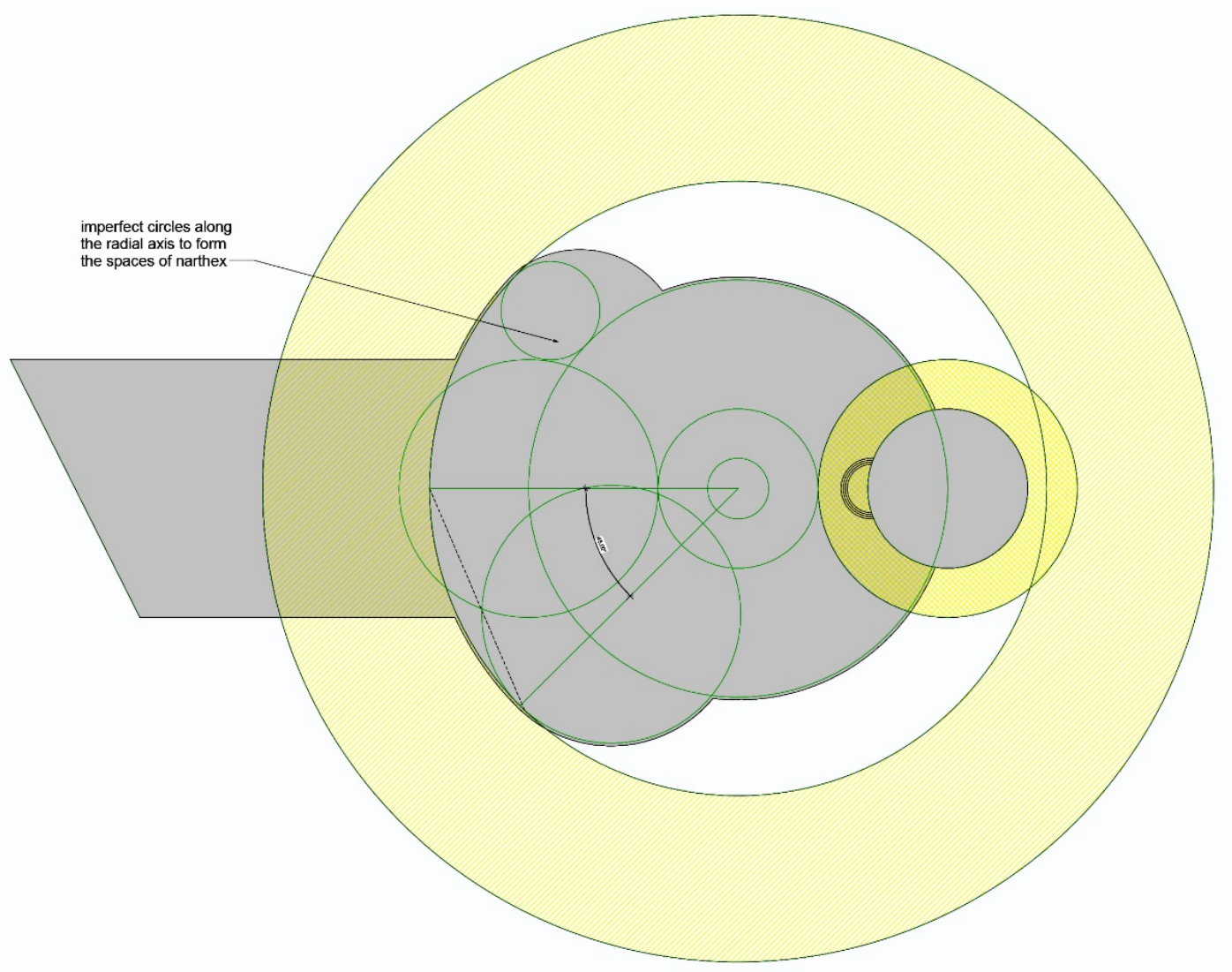

Figure 18. Geometric composition of the church spaces - narrative in form of the spatial articulation 


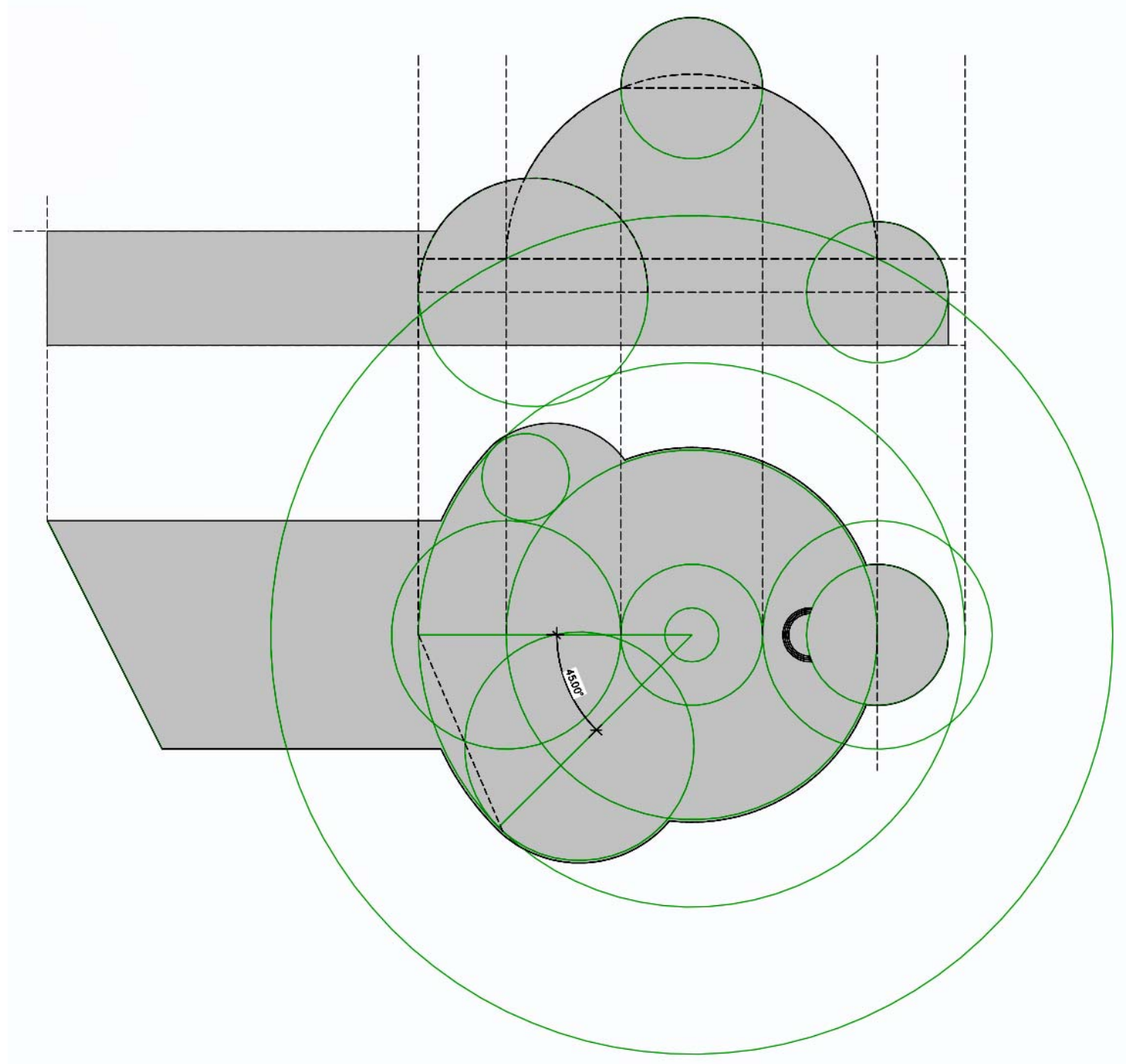

Figure 19. Proportional composition of the church building geometry (the golden mean) 


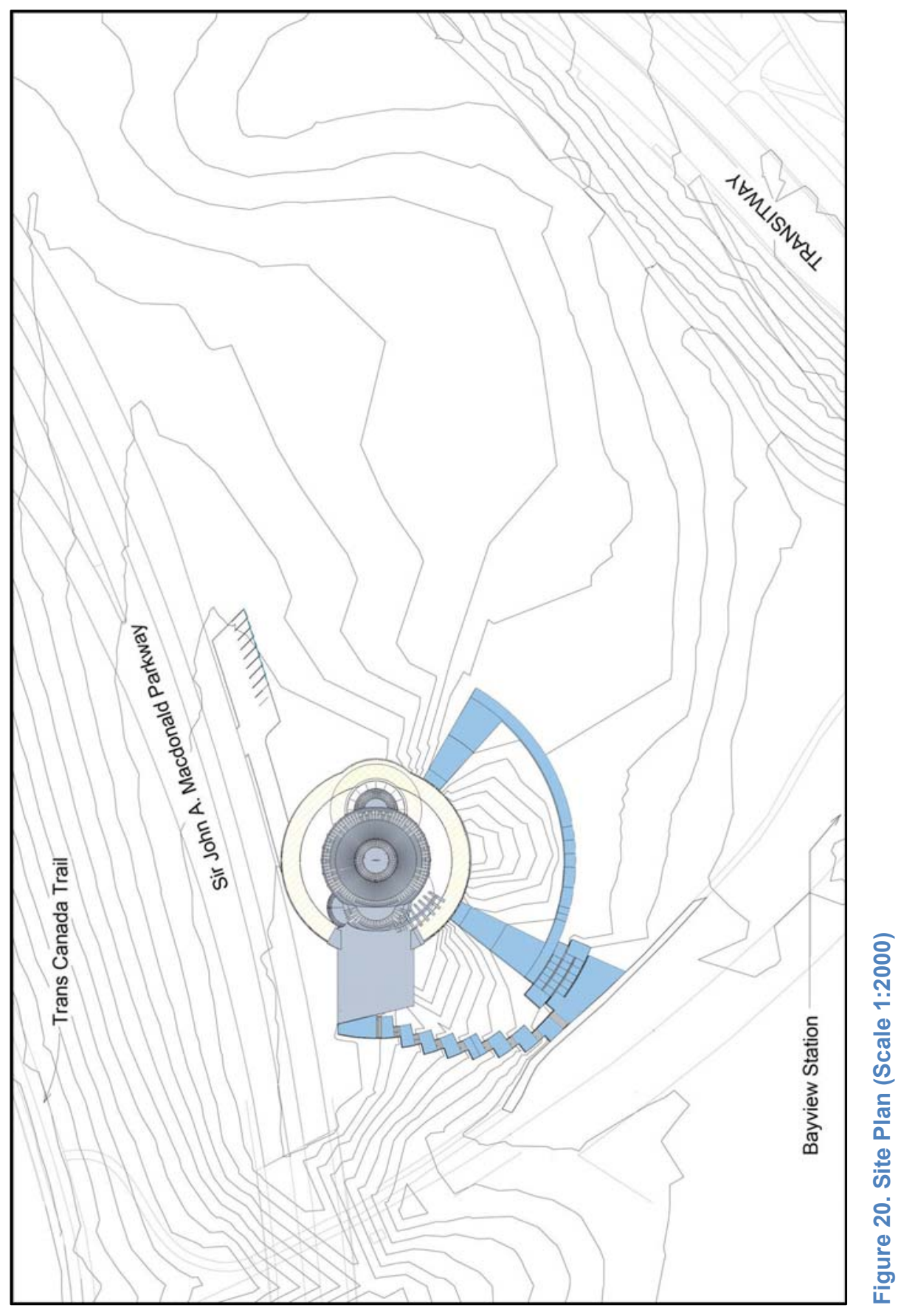




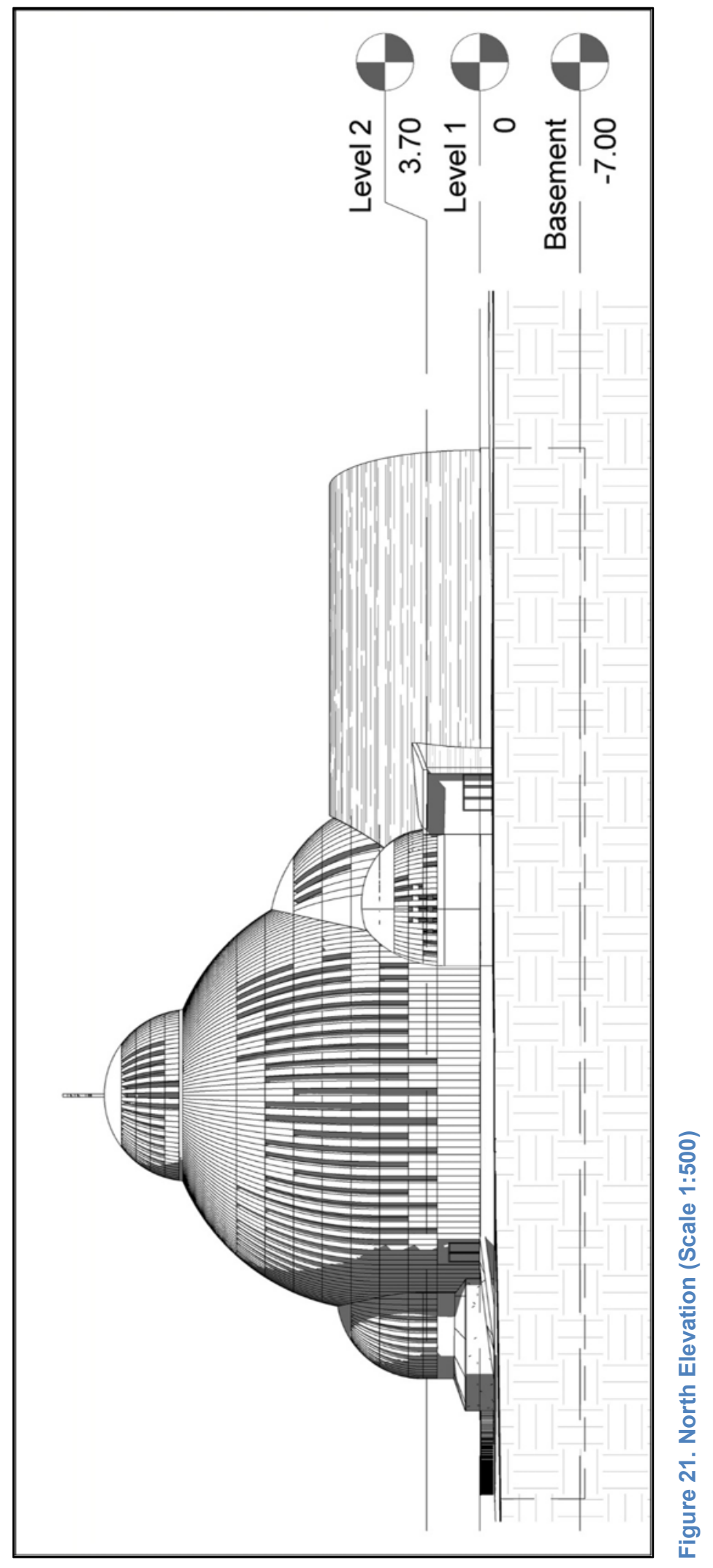




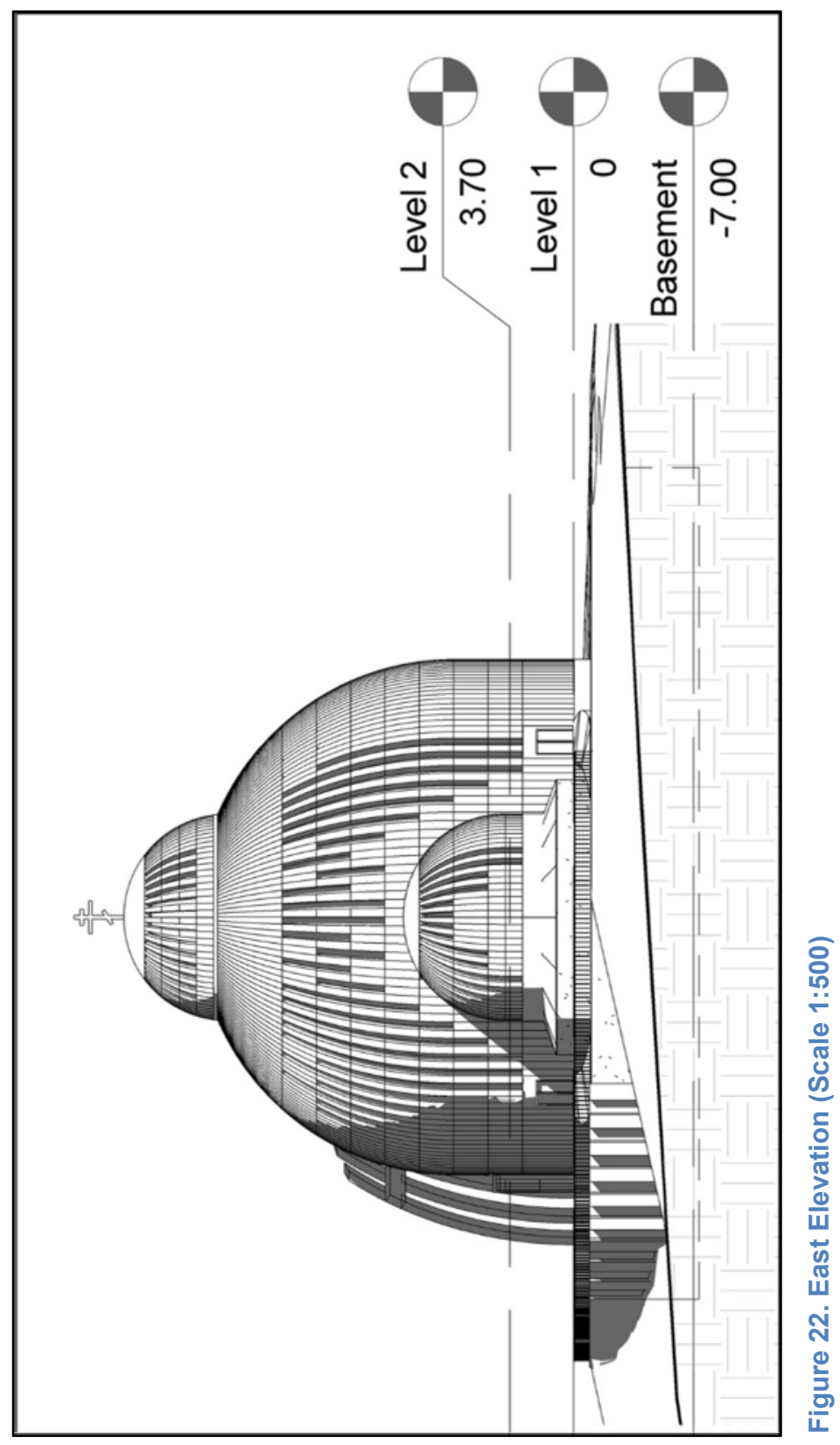




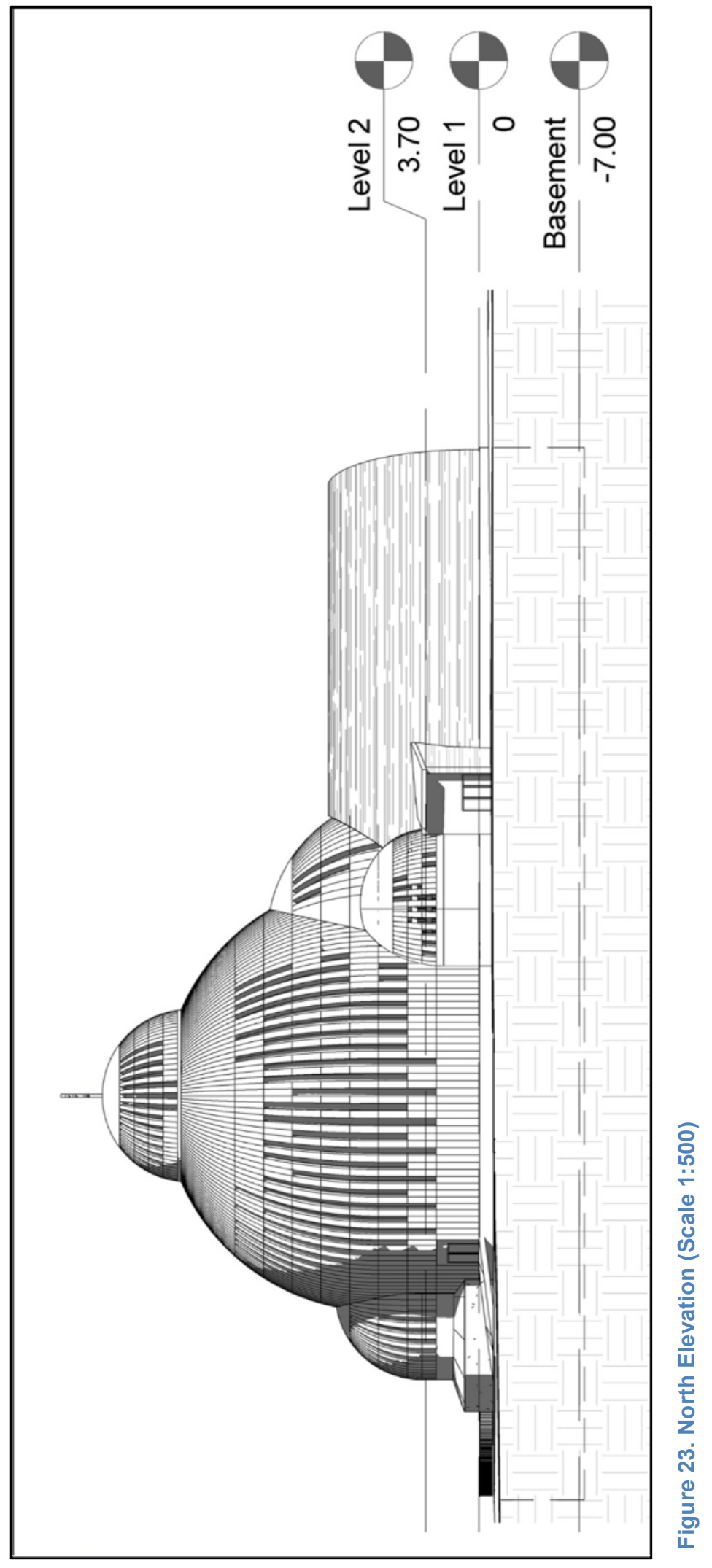




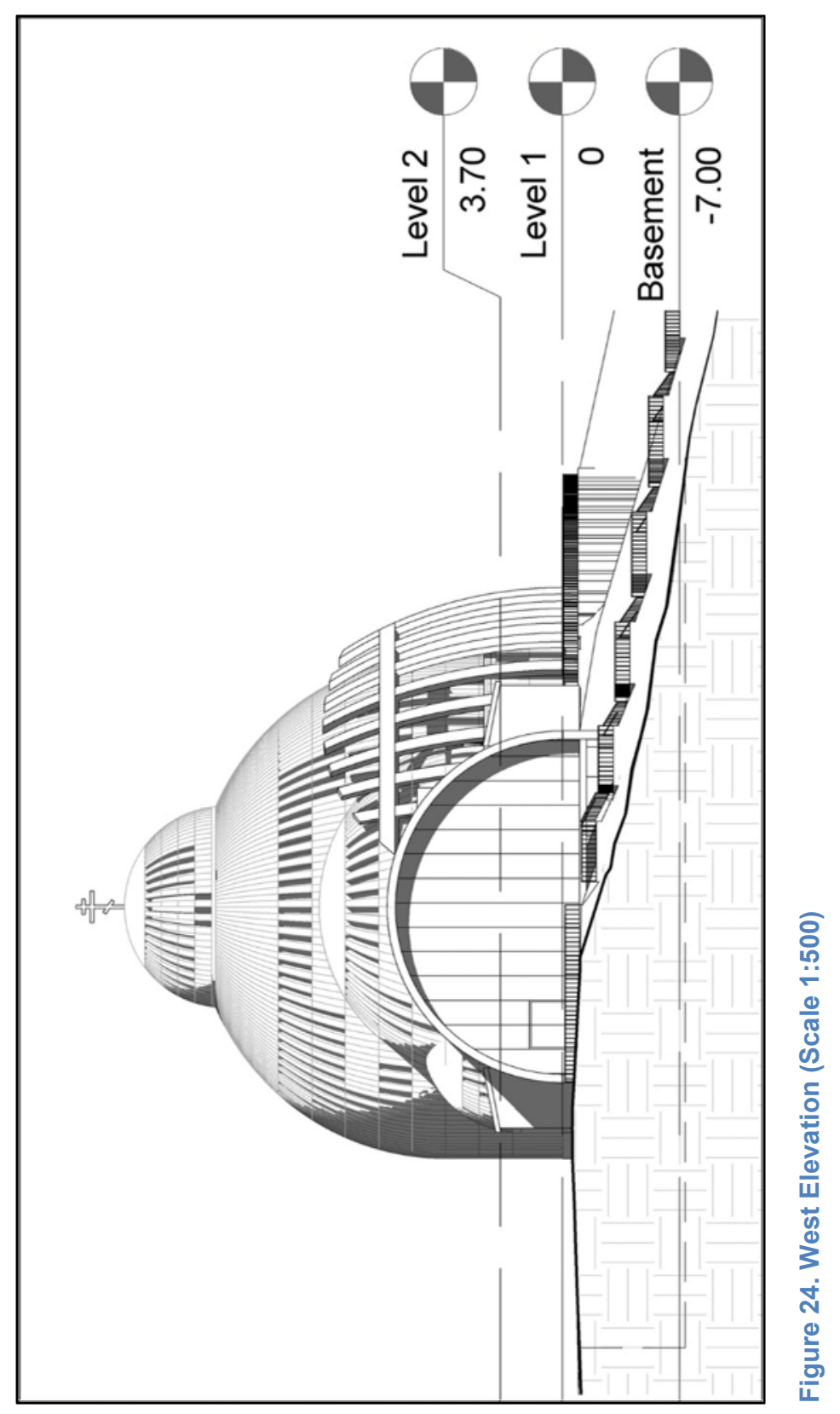




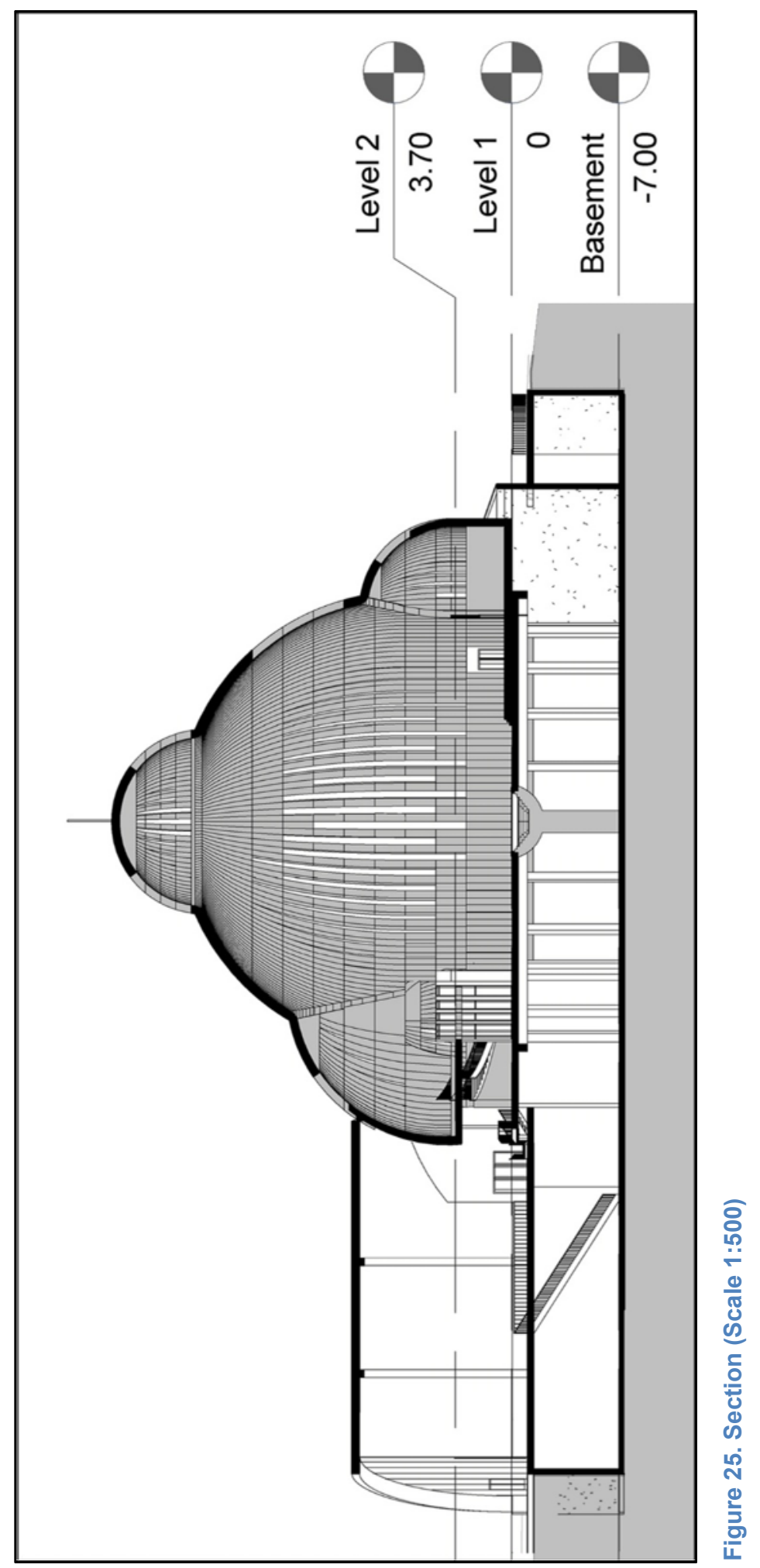




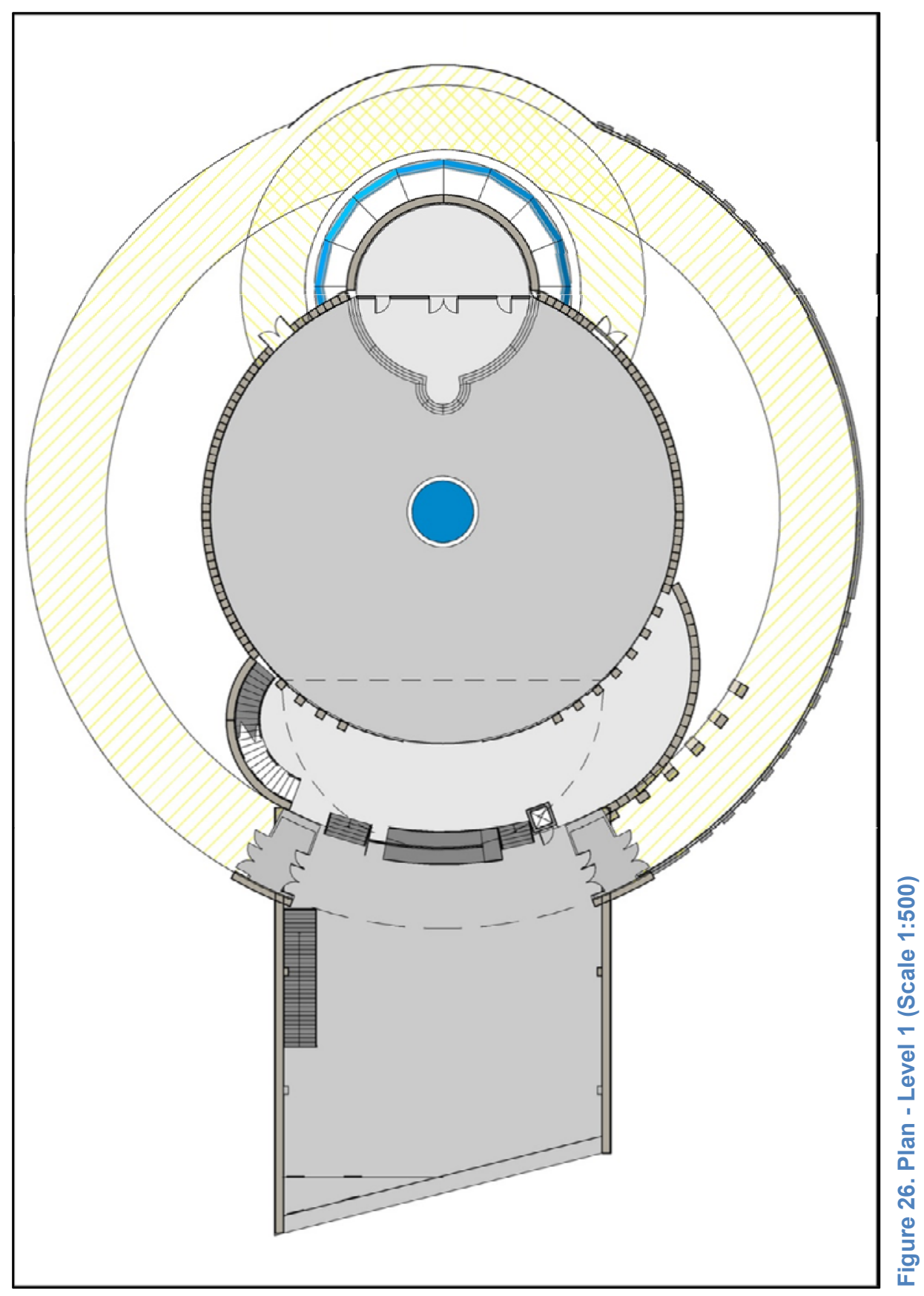




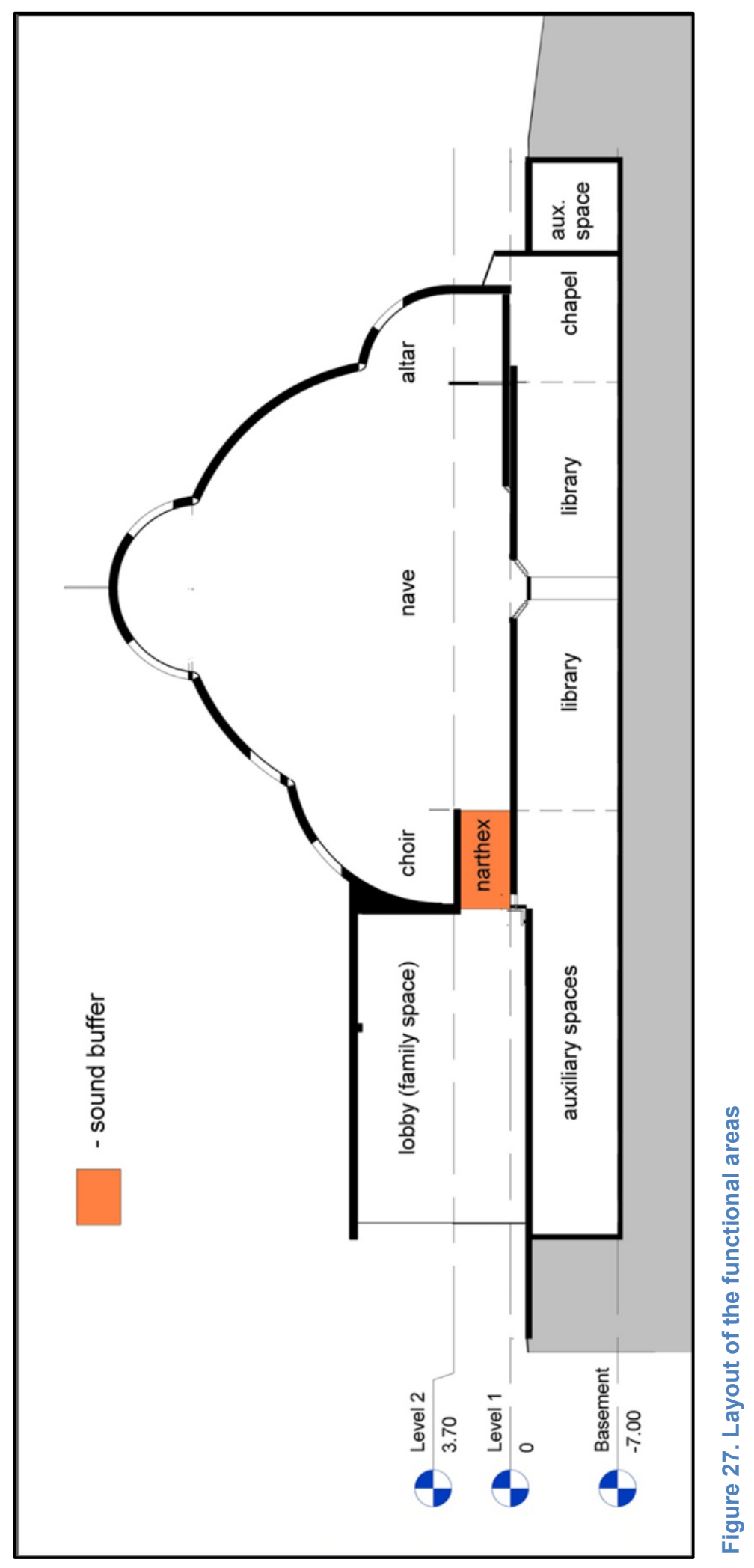




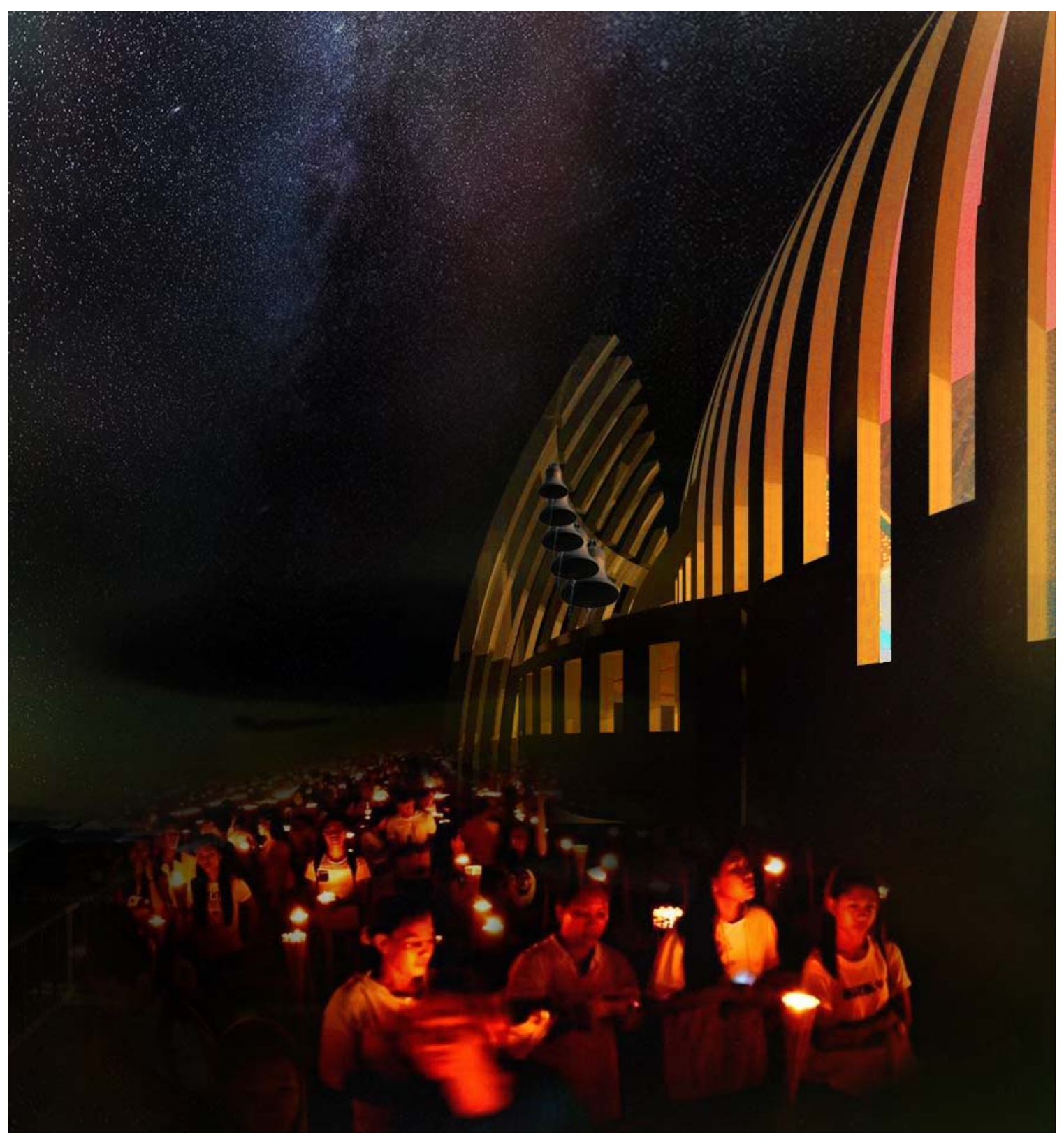

Figure 28. Processional paths (view of the belfry) 

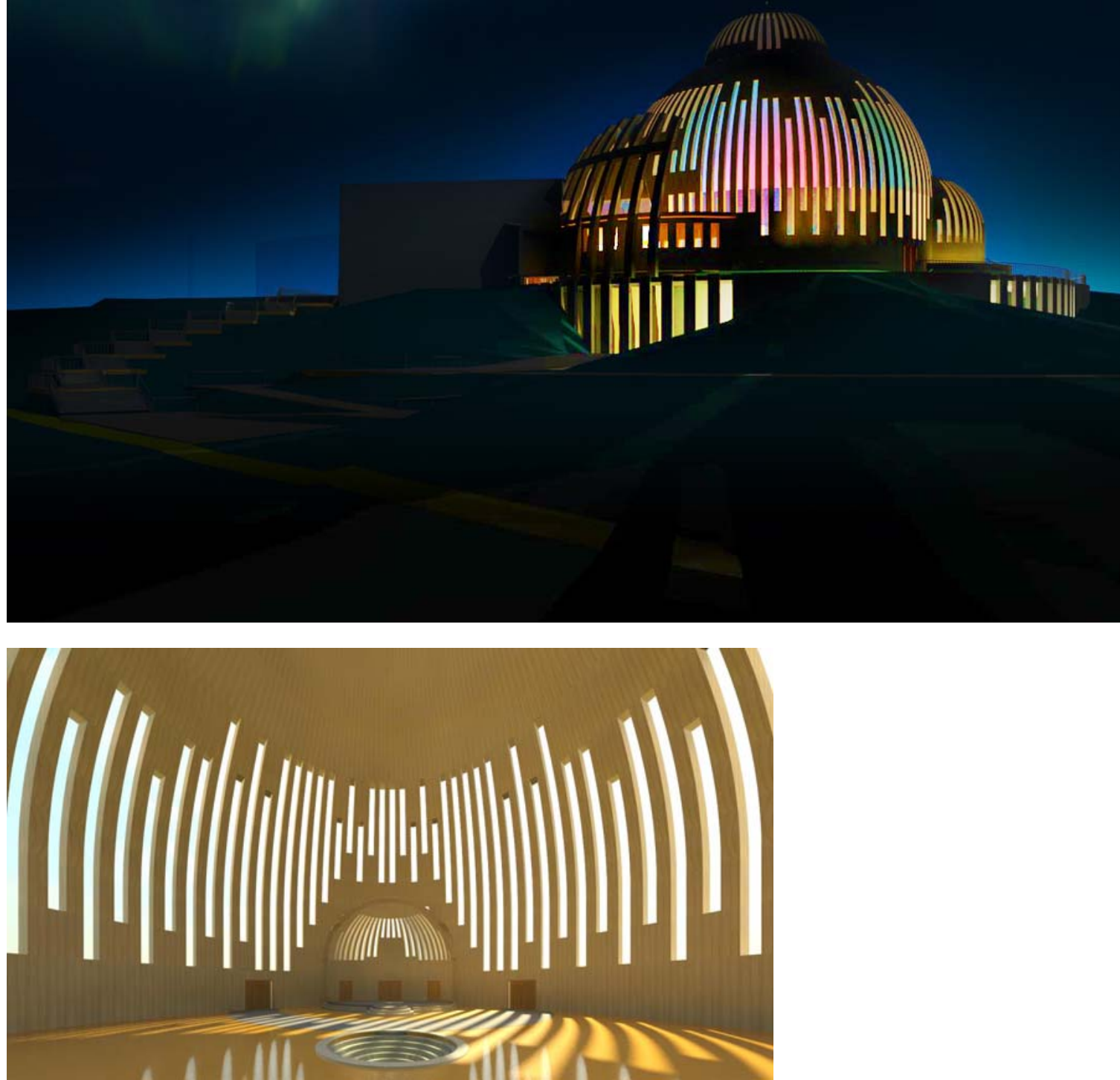

Figure 29. Arrangement of windows: random on outside, balanced and symmetrical on inside 


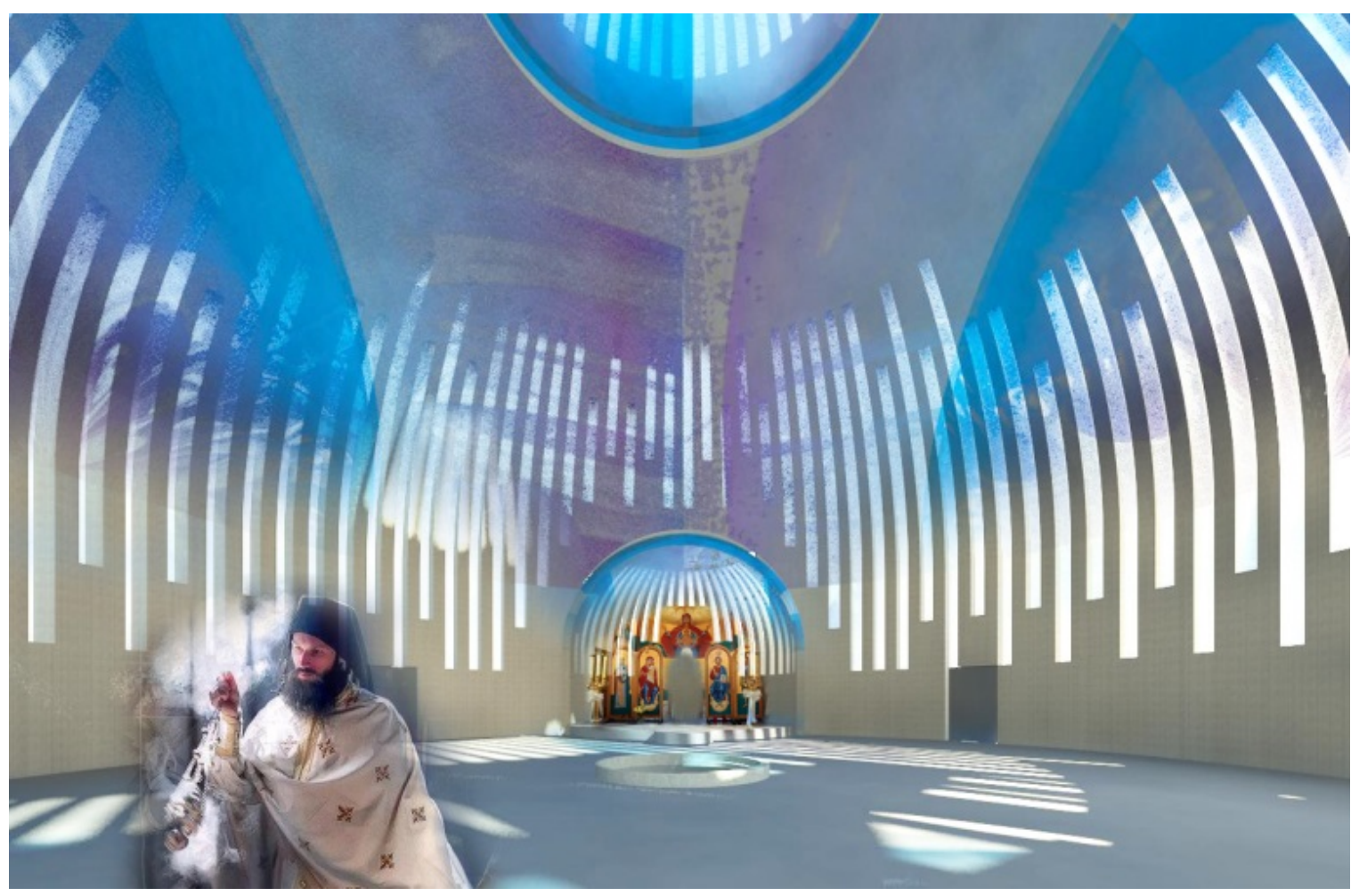

Figure 30. Interior of the church - daytime

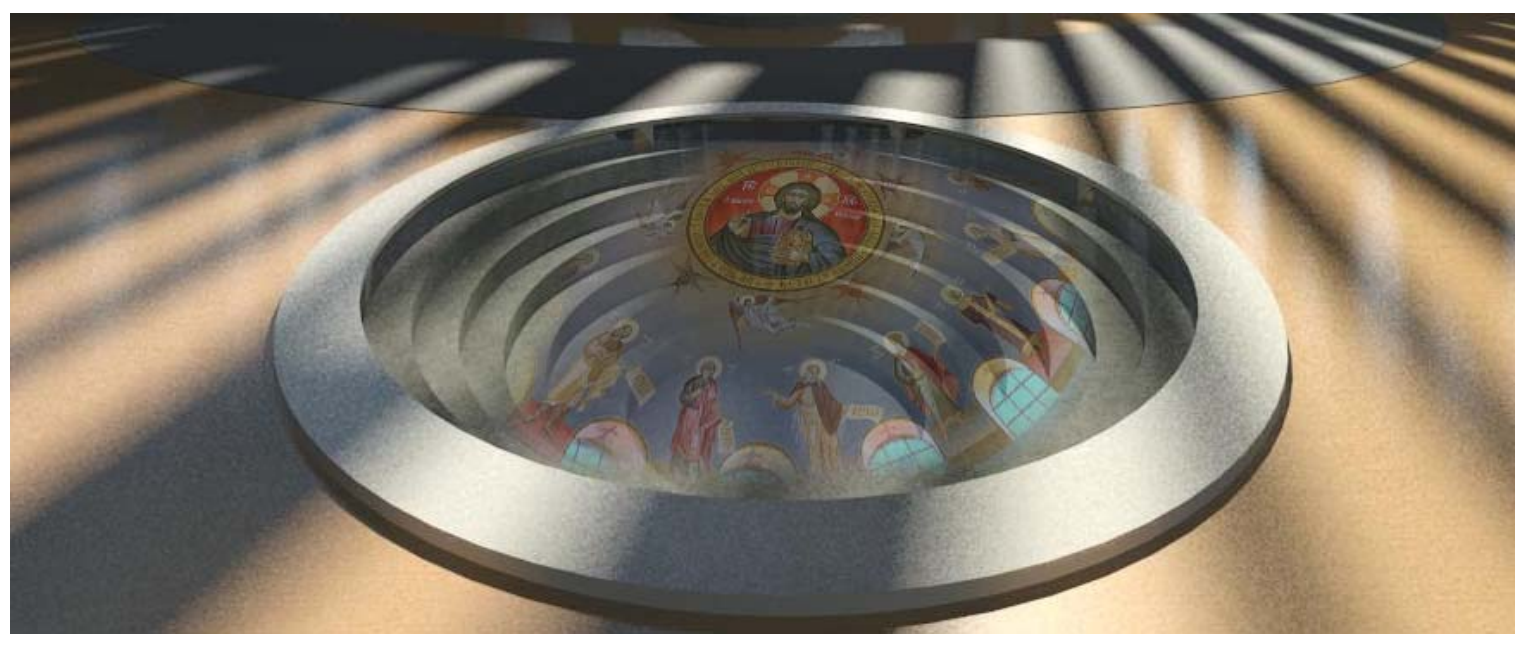

Figure 31. Baptistery 


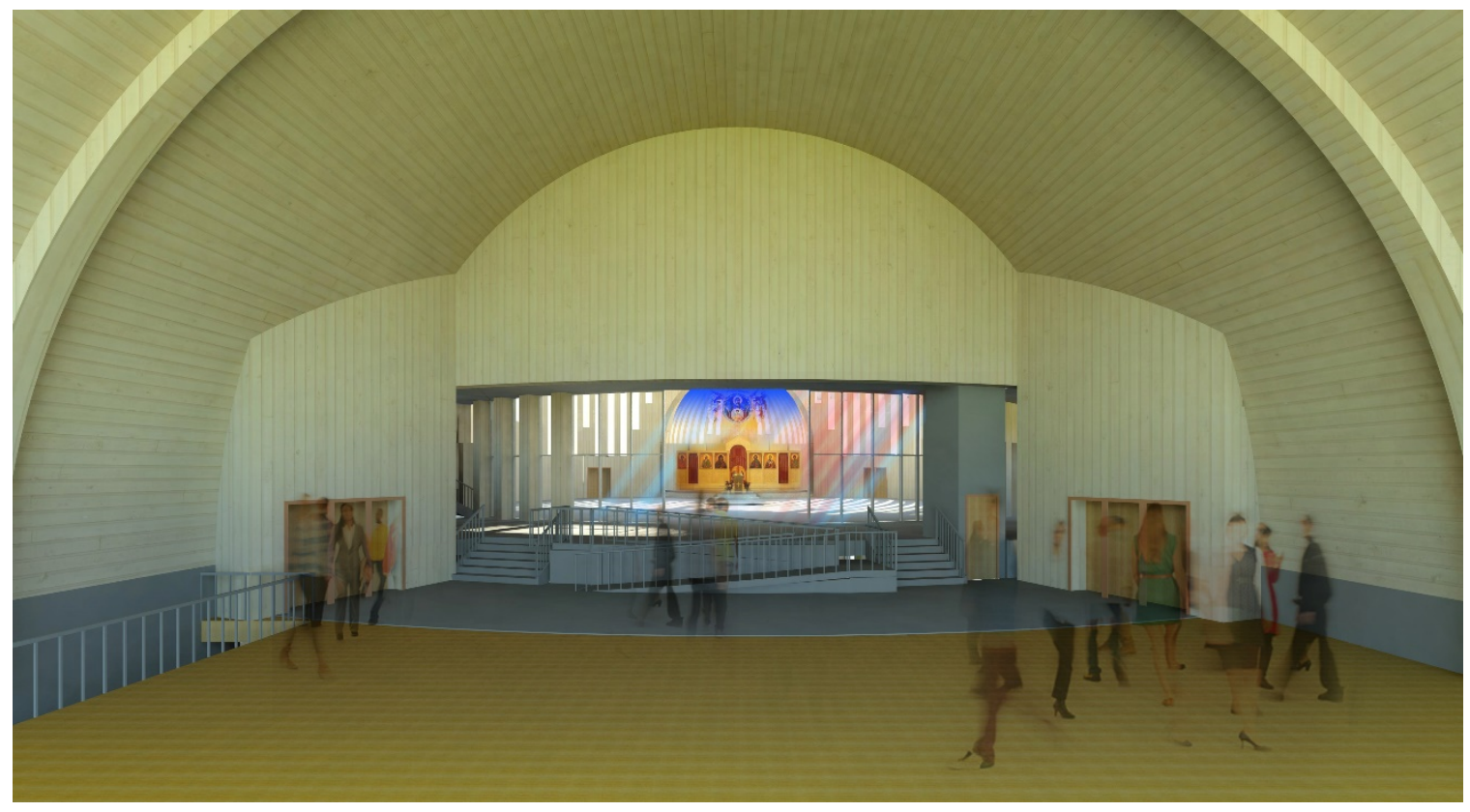

Figure 32. Inside the lobby ("family space")

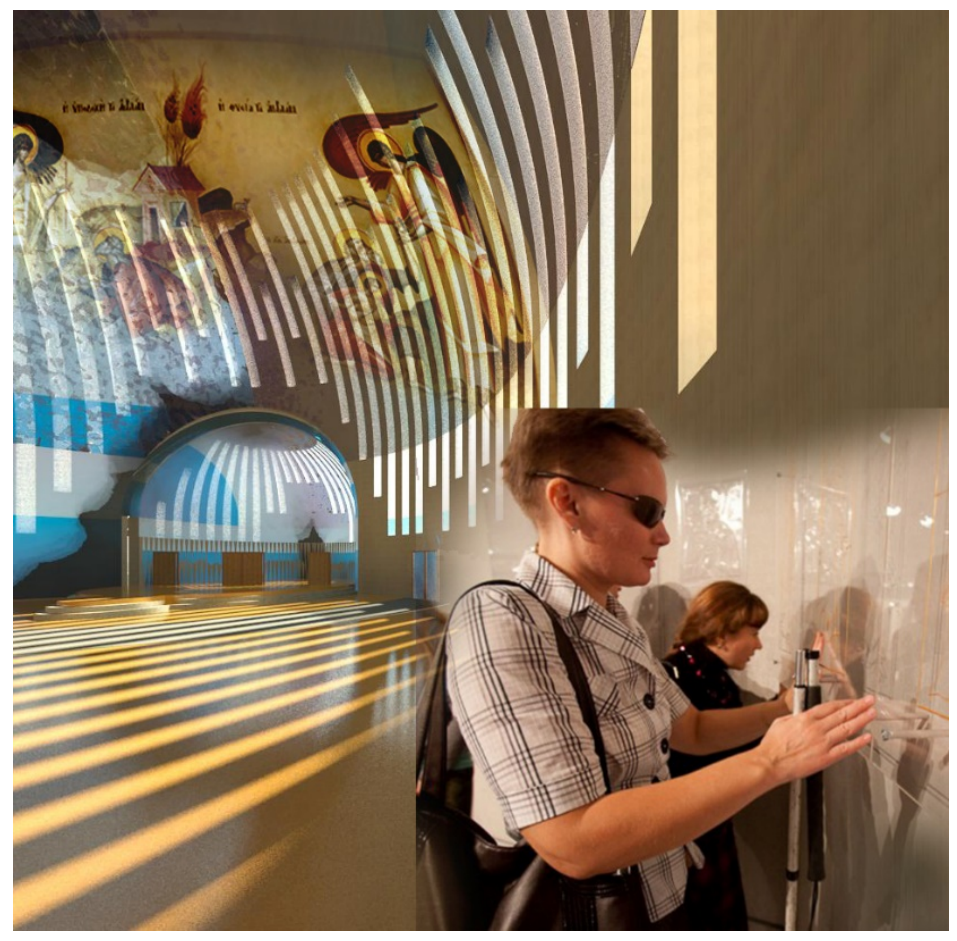

Figure 33. Interior walls with carved monochrome icons - tactile environment 


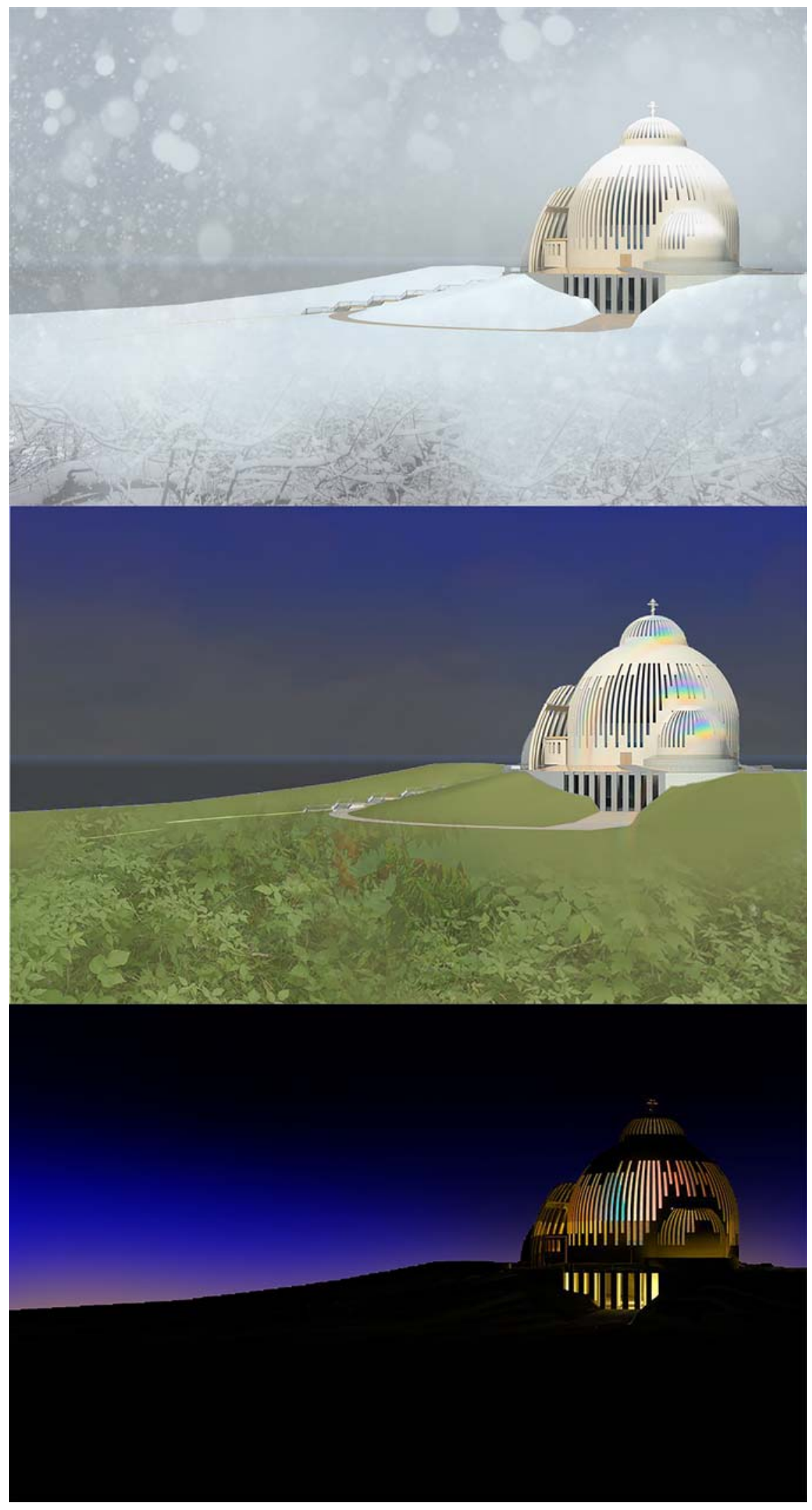

Figure 34. Changes in the building manifestation on site (subtle presence, rainbow effect, Aurora Borealis effect) 

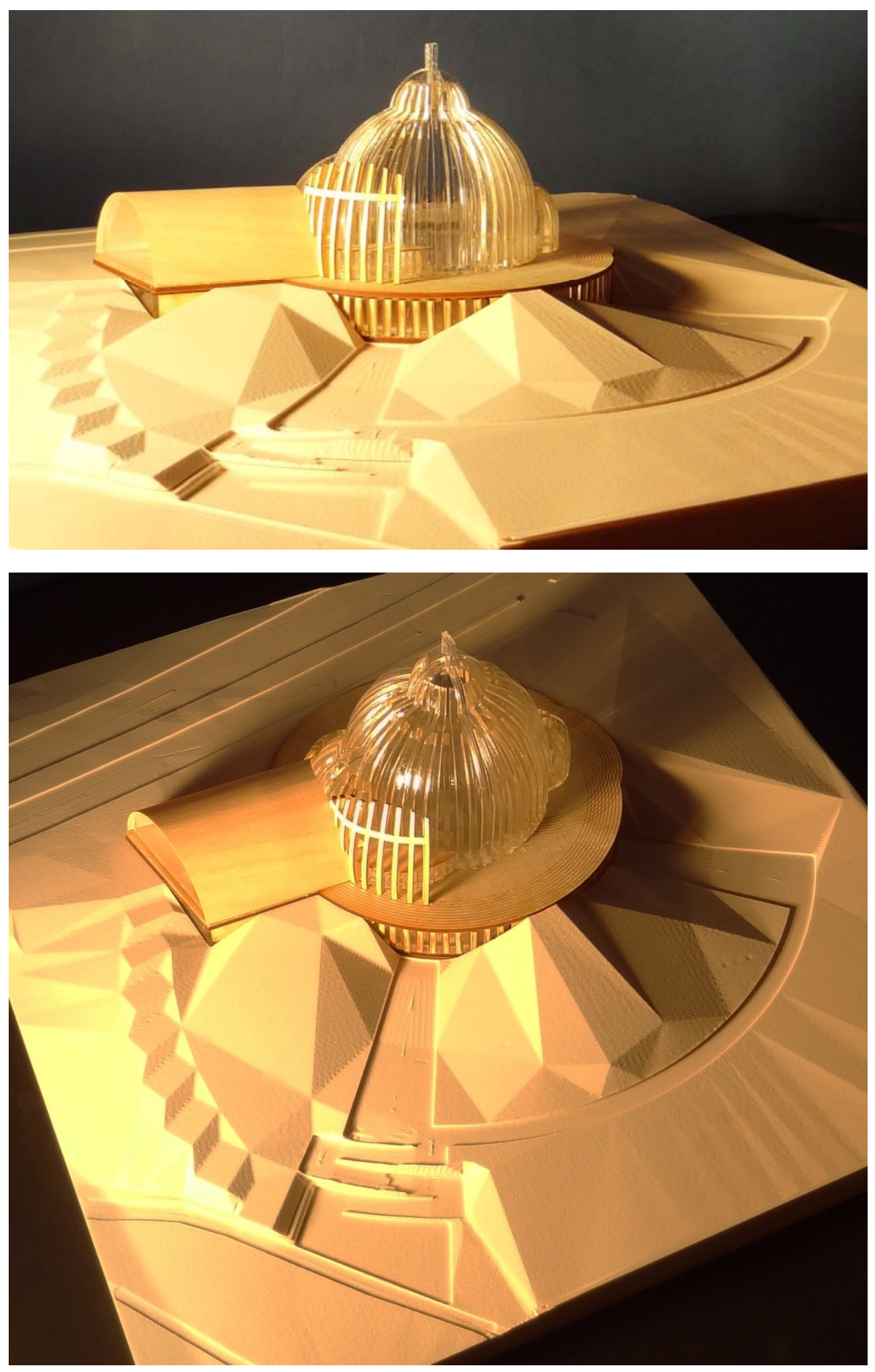

Figure 35. Physical model (terrain) 

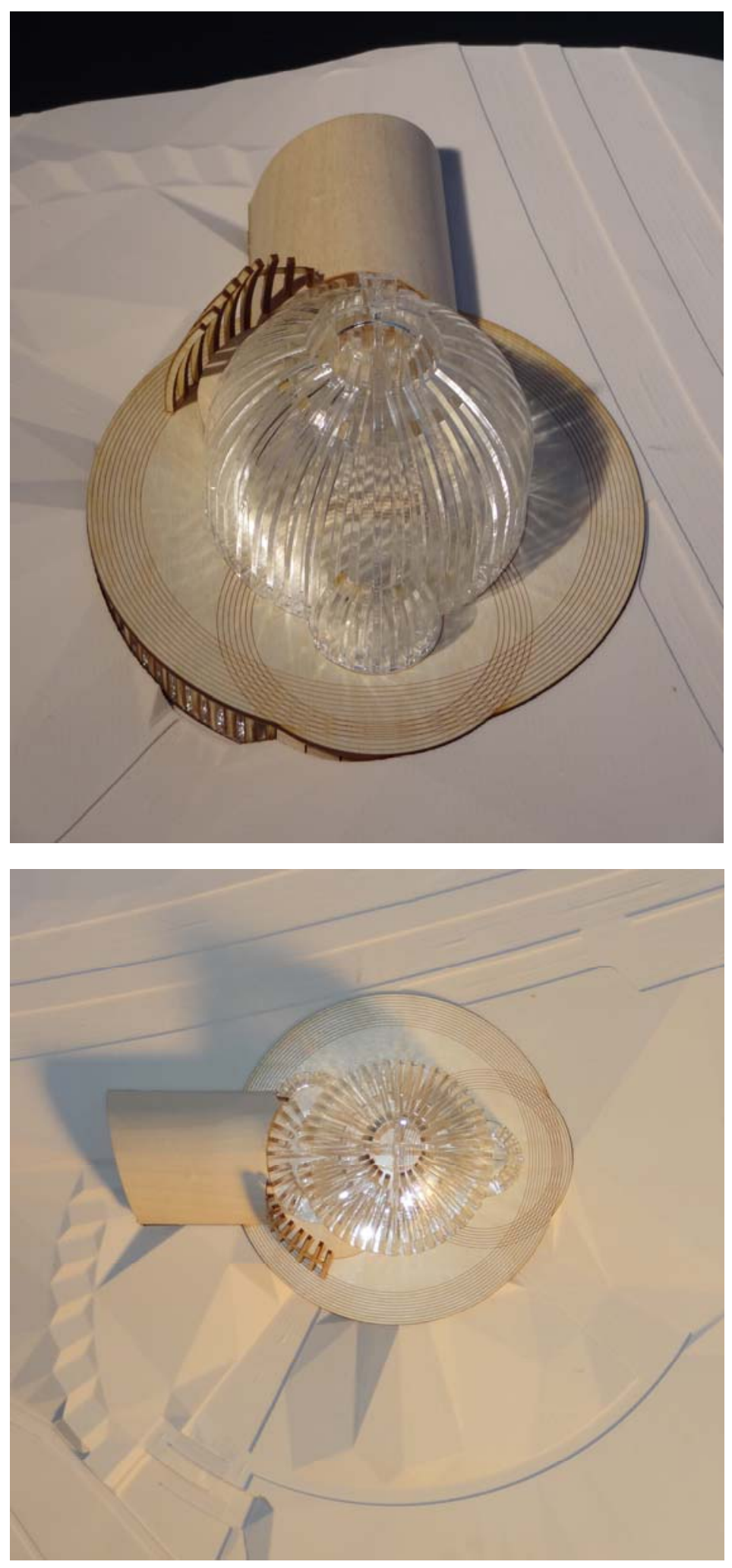

Figure 36. Physical model (materiality) 


\section{Postscript}

The approach to the conceptual design of a contemporary Orthodox Christian church is a way of responding to the various challenges of the contemporary sacred architecture design in general and Orthodox Christian Church design in particular. The approach consists of the following steps: outlining the meta-function of the prospective building; defining the intended users of space and their needs, as well as the social, spatial, and temporal context; creating an environment (a microcosm); composing the architectural narrative. Unlike other cultural buildings, the church functions as an "environment", rather than a "signifier" in a built form. The steps of the approach focus the design of the building on its most important function, because the outward expression of the church is secondary to its purpose. In essence, the approach is a method for creating an environment for a particular event to take place: in case of the church - a set up for the liturgy. The approach also creates a technique for using the architectural expression provided by the new architectural styles and materials without interfering with the main purpose of the building.

As illustrated in the thesis project, the approach allows creating the contemporary Orthodox Christian church building that responds to the current socio-cultural, temporal and spatial context. In addition to the inherent architectural narrative of the church building, the approach incorporates the supplementary layers of the narrative that draw upon the architectural design experience of other cultures, the particular needs of a contemporary dweller, and specifics of the locality. The "translation" of the narrative is achieved by finding a common ground between the various cultures in the form of architectural symbolism and the use of design components. The resulting new architectural image of the church has a potential to appear recognizable to the entire diverse community. 
Other types of buildings, particularly the ones that deal with the transitional stages of our lives (places of learning, places of public gathering, etc.) can also benefit from the use of the approach, since the approach is based on the immutable architectural principles and can function as an anchor, a reference point in a state of the transition. 


\section{Bibliography}

Allen, Edward, and Joseph lano. 2011. The Architect's Studio Companion: Rules of Thumb for Preliminary Design. Hoboken, New Jersey: John Wiley \& Sons.

Anisimov, Andrey, interview by Anton Leontyev. 2011. Беседа с архитектором Андреем Анисимовым [The Conversation with the Architect Andrei Anisimov] (10 5). Accessed 12 5, 2014. http://www.pravoslavie.ru/guest/49052.htm.

Arakawa, and Madeleine Gins. 2002. Architectural Body. Tuscaloosa: University of Alabama Press.

Arakawa, Shusaku et al. 1997. Reversible Destiny: Arakawa/Gins. New York: Guggenheim Museum Publications NYC.

Arakawa, Shūsaku, Madeleine Gins, and Jean-Jaques Lecercle. 2006. Making Dying Illegal: Architecture Against Death: Original to the 21st Century. New York: Roof Books.

Bagina, Elena. 2014. "Are New Forms Necessary for Orthodox Christian Temples?" Project Baikal (11): 36-9.

Baidine, Valery. 2012. O novom obraze russkogo hrama. Russkiy Hram: XXI vek. [On the New Image of the Russian Temple. Russian Temple: 21 Century]. Translated by Translated by Author. Accessed 11 16, 2015. http://www.archi.ru/lib/e_publication_for_print.html?id=1850569920.

Bhaskaran, Lakshmi. 2005. Designs of the Times: Using Key Movements and Styles for Contemporary Design. New-Your: RotoVision.

Centre of Architecture and Art of the Moscow Patriarchate. 2003. "Православные храмы. Пособие по проектированию и строительству к СП 31-103-99 [Orthodox churches. Manual for the design and construction to SP 31-103-99]." Православные храмы и комплексы [Orthodox churches and complexes]. Vol. 2. Compiled by Mikhail Kesler. Moscow: Гуп Цпп.

—. 2004. "Православные храмы. Пособие по проектированию и строительству к СП 31-103-99 [Orthodox Temples. Manual for the Design and Construction supplementary to SP 31-103-99]." Примеры архитектурно-строительных peшений [Examples of architectural solutions]. Vol. 3. Compiled by Mikhail Kesler. Moscow: Гуп Цпп.

—. 2003. "Православные храмы. Пособие по проектированию и строительству к СП 31-103-99 [Orthodox churches. Manual for the design and construction to SP 31103-99]." Православные храмы и комплексы [Orthodox churches and complexes]- Ideya i Obraz [Idea and Image]. Vol. 1. Compiled by Mikhail Kesler. Гуп Цпп.

Chapman, Wid, and Jeff Rosenfeld. 2011. Unassisted Living: Ageless Homes for Later Life. New York: Monacelli Press. 
Chukina, Anna. 2012. "Послание к иконописцу, или Несколько слов о работе искусствоведа (Epistle to the Icon Painter, or a Few Words on the Work of an Art Critic)." Храмоздатель (Temple Builder) 66-68.

Coates, Nigel. 2012. Narrative Architecture: Architectural Design Primers series. Hoboken, New Jersey: Wiley.

Faustova, Milena. 2011. Храм каменный, купола фраророровые [A Temple of Stone, Domes of Porcelain]. 5 17. Accessed 12 15, 2014. http://www.pravmir.ru/xramkamennyj-kupola-farforovye/.

Fetisova, Elena. 2014. Осторожно, дети! Нюансы хождения в храм вместе $c$ детьми. [Caution, Children! Nuances of Going to Church with Children]. 1103. Accessed 11 16, 2015. http://www.pravoslavie.ru/jurnal/74827.htm.

Frampton, Kenneth. 2007. Modern Architecture: a Critical History. London; New York: Thames \& Hudson.

Franko, Olga. 2014. "Modern Architectural Decision for the Image of an Orthodox Temple." Project Baikal (11): 46-9.

Grigoryeva, Elena. 2014. "Temples XXI." Project Baikal (11): 1-4.

Keane, Jondi. 2013. "Initiating Change: Architecting the Body-Environment with Arakawa and Gins." Architectural Design (83.1): 76-83.

Kesler, Mikhail. 2013. "Temple Architecture: Features, Meanings, Objectives [Храмовое зодчество: особенности, смыслы, задачи]." Храмоздатель (Temple Builder) 12-20.

Kesler, Mikhail. 2015. "Конструктивные решения и строительные материалы [Design Solutions and Building Materials]."

Kesler, Mikhail. 2015. "Объемно-планировочные [Space-Planning Solutions of Orthodox Christian Temples]." (2).

Kral, Francoise, and Jean Jaques Lecercle. 2010. Architecture and Philosophy. New Perspectives on the Work of Arakawa \& Madeleine Gins. Amsterdam - New York.

Kroeker, Richard. 2013. "Learning from Native American Architecture." DETAIL 338-341.

Leontyev, Anton. 2013. Может ли храм быть современным? [Can the Temple be Contemporary?]. 3 16. Accessed 12 12, 2014.

http://ruskline.ru/analitika/2013/03/16/mozhet_li_hram_byt_sovremennym/.

Lidwell, William, Jill Butler, and Kritina Holden. 2003. Universal Principles of Design. Gloucester, Mass: Rockport.

Linde, Yuliya. 2011. "Иконы Для Незрячих [Ikony dlia nezriachikh/ Icons for the Blind]." Фома [Thomas]. Accessed 11 16, 2015. http://foma.ru/ikonyi-dlyanezryachix.html. 
Lomholt, Isabelle. 2011. Russian Cultural Centre + Orthodox Worship, Paris. 324. Accessed 1 19, 2015. http://www.e-architect.co.uk/paris/russian-cultural-centre.

Long, Susan O., ed. 2000. Caring for the Elderly in Japan and the US: Practices and Policies. London; New York: Routledge.

Lynch, Kevin. 1960. The Image of the City. Cambridge, MA: Technology Press.

Mahnke, Frank H. 1996. Color, Environment, and Human Response: An Interdisciplinary Understanding of Color and Its Use as a Beneficial Element in the Design of the Architectural Environment. New York: Van Nostrand Reinhold.

Nakagawa, Takeshi. 2005. The Japanese House: in Space, Memory, and Language. Translated by Geraldine Harcourt. Tokyo, Japan: International House of Japan.

Nitschke, Günter. F. 1993. From Shinto to Ando: Studies in Architectural Anthropology in Japan. London: Academy Editions.

Ostrovskiy, Konstantin. 2013. "Спор старого и нового о вечном (The Dispute Between the Old and the New on the Subject of Eternal)." Temple Builder (Храмоздатель) 20-24.

Ostrovsky, Konstantin. 08. Заметки о модернизме в церковной архитектуре [Zametki o modernizme $v$ tserkovnoj arkhitekture/Notes on Modernism in Church Architecture]. Русская народная линия [Russkaya narodnaya liniya]. 032013. Accessed 11 16, 2015. http://ruskline.ru/analitika/2013/03/08/zametki_o_modernizme_v_cerkovnoj_arhit ekture/.

Ouspensky, Leonid. 1948. "Simvolika Hrama [Symbolism of the Temple]." Jurnal Moskovskoj Patriakhii [The Journal of Moskow Patriarkhy] (1): 37-47.

Ouspensky, Leonid. 1992. "Vopros ikonostasa. [the Question of Iconostasis]." M. (M.) $17,18,27$.

Richardson, Phyllis. 2004. New Sacred Architecture. London: Laurence King.

Royal Institute of British Architects. 2011. A Guide for Assisted Living: Towards LifeHome 21. London: RIBA Enterprises.

Shangin, Nikita. 2014. "Размышления по итогам конкурса на образ православного храма [razmyshleniya po itogam konkursa na obraz pravoslavnogo khrama/thoughts on the results of the competition for the image orthodox church]." Aрхитектурный вестник [Arkhitekturniy Vestnik/Architectural Herald] (2 (137)). Accessed 11 16, 2015. http://archvestnik.ru/node/10457.

Sidelnikova, Maria, and Aleksey Tarkhanov. 2014. Храм неизвестного святого [Temple of an Unknown Saint]. 1 18. Accessed 12 15, 2014. http://www.kommersant.ru/doc/2387334.

Sikhatova, Rusina. 2014. Le nouveau Centre spirituel et culturel orthodoxe russe présenté à Paris. 1 17. Accessed 1 15, 2015. http://www.lecourrierderussie.com/2014/01/centre-spirituel-russe-paris/. 
Smith, Peter F. 1998. Architecture and the Principle of Harmony. London: Intl Specialized Book Service Inc.

Sokolov, Dmitry. 04. Инфрормационная война в архитектуре [Informatsionnaya voyna v arkhitekture/Information War in Architecture]. 04 2013. Accessed 11 16, 2015.

http://ruskline.ru/analitika/2013/04/04/informacionnaya_vojna_v_arhitekture/.

Staniloae, Dumitru. 1994. Orthodox Dogmatic Theology: The Experience of God. 1998 reprint. Edited by loan lonita and Robert Barringer. Translated by loan loanita and Robert Barringer. Vol. 1. Revelation and Knowledge of the Triune God. 3 vols. Brookline, Massachussetts: Holy Cross Orthodox Press.

Tarabarina, Yuliya. 2011. Архитектура компромисса [Architecture of Compromise]. 3 23. Accessed 12 1, 2014. http://archi.ru/world/32344/arhitektura-kompromissa.

Thiis-Evensen, Thomas. 1987. Archetypes in Architecture. Oslo: Norwegian University Press.

Vitruvius. 1960. The Ten Books on Architecture. Translated by Morris H. Morgan. New York: Dover Publications.

Volodin, Mikhail, and Andrey Anisimov. 2015. "Зачем должен совпадать радиус алтаря и купола? [Zachem dolzhen sovpadat' radius altaria i kupola?/Why should the Radii of Altar and Main Dome be the same?]." Edited by Irina Redko. Нескучный сад [Neskuchniy sad]. Accessed 11 16, 2015. http://www.nsad.ru/articles/kak-ustroen-hram-altar.

Wilmotte \& Associés. n.d. Centre Spirituel et Culturel Orthodoxe Russe. Accessed 119 , 2015. http://www.wilmotte.com/fr/projet/404/Centre-Spirituel-et-Culturel-Russe.

Wise, Jeff. 2012. "Arctic Engineering." 189 (2): 38-41.

Агентство архитектурных новостей [Architectural News Agency]. 2014. Eще раз [Once Again]. 1 18. Accessed 12 15, 2014.

http://www.archi.ru/world/52596/obnarodovan-novyi-proekt-russkogo-kulturnogocentra-v-parizhe.

2014. История возникновения духовно-культурного православного центра в Париже [The Story of the Spiritual and Cultural Orthodox Christian Center in Paris]. 3 2. Accessed 12 15, 2014. http://kommersant.ru/doc/2396190. 